UNIVERSIDADE DE SÃO PAULO

FACULDADE DE ECONOMIA, ADMINISTRAÇÃO E CONTABILIDADE DEPARTAMENTO DE CONTABILIDADE E ATUÁRIA

PROGRAMA DE PÓS-GRADUAÇÃo EM CONTROLADORIA E CONTABILIDADE

FERNANDO TORRES BAPTISTA DA COSTA

Relação entre cobertura da mídia, valor das empresas e liquidez das ações 
Prof. Dr. Marco Antonio Zago

Reitor da Universidade de São Paulo

Prof. Dr. Adalberto Américo Fischmamn

Diretor da Faculdade de Economia, Administração e Contabilidade

Prof. Dr. Gerlando Augusto Sampaio Franco de Lima

Chefe do Departamento de Contabilidade e Atuária

Prof. Dr. Andson Braga de Aguiar

Coordenador do Programa de Pós-Graduação em Controladoria e Contabilidade 


\section{Relação entre cobertura da mídia, valor das empresas e liquidez das ações}

Dissertação apresentada ao Programa de PósGraduação em Controladoria e Contabilidade da Universidade de São Paulo, como parte dos requisitos para obtenção do título de Mestre em Ciências

Orientador: Prof. Dr. Alexsandro Broedel Lopes

Versão Corrigida

(versão original disponível na Faculdade de Economia, Administração e Contabilidade)

\section{SÃO PAULO}


FICHA CATALOGRÁFICA

Elaborada pela Seção de Processamento Técnico do SBD/FEA/USP

Costa, Fernando Torres Baptista da.

Relação entre cobertura da mídia, valor das empresas e liquidez das ações / Fernando Torres Baptista da Costa. -- São Paulo, 2015. $97 \mathrm{p}$.

Dissertação (Mestrado) - Universidade de São Paulo, 2015.

Orientador: Alexsandro Broedel Lopes.

1. Mercado de capitais. 2. Jornalismo econômico. 3 Assimetria de informação. 4. Meios de comunicação. 5. Ações. 6. Bolsa de valores. I. Universidade de São Paulo. Faculdade de Economia, Administração e Contabilidade. II. Título. 
Ao meu filho Dudu, à minha mulher Ticá, ao meu pai Dotinho e à minha mãe Zezé, que acompanhou à distância. 


\section{AGRADECIMENTOS}

Apenas 350 metros separam a Escola de Comunicações e Artes (ECA) da Faculdade de Economia Administração e Contabilidade (FEA), ambas localizadas no campus principal da Universidade de São Paulo. Mas acredito que seja um dos poucos que tenha se arriscado a cruzar a Av. Prof. Lúcio Martins Rodrigues sem que fosse apenas para almoçar no Sweden.

E tenho muito a agradecer por aqueles que me ajudaram e incentivaram a fazer essa travessia, que demorou bem mais do que os 4 minutos a pé indicados pelo Google Maps.

Um mestrado não se faz sozinho, e nem apenas com a ajuda do orientador. São muitas pessoas envolvidas, o que me leva a seguir um roteiro, para tentar não me esquecer de ninguém.

O professor Eliseu Martins talvez seja o principal culpado de todo o processo. Quando ainda estava na Comissão de Valores Mobiliários (CVM), foi ele que me ensinou o que sei de contabilidade e também quem me ensinou a gostar de contabilidade. O professor Eliseu também foi um dos maiores entusiastas quando lhe disse e pela primeira vez que ia tentar fazer o mestrado na FEA.

Alexandro Broedel, meu orientador neste trabalho, também é um responsável antigo por este mestrado. Desde que assumiu a batuta deixada por Eliseu na diretoria do órgão regulador do mercado de capitais no fím de 2009 , começou a me "orientar" por meio de entrevistas e conversas frequentes sobre o processo de transição do modelo contábil brasileiro para o IFRS e também sobre mercado de capitais de maneira mais ampla.

Ainda no corpo docente da FEA, não posso deixar de mencionar o professor Nelson Carvalho. Não só pela oportunidade que tive de estudar Teoria da Contabilidade com ele, como também por ter me dado indicações relevantes sobre os caminhos que deveria seguir durante todo o curso, e pelo profissionalismo e seriedade.

Também gostaria de agradecer ao professor Gerlando Lima, que contribuiu na definição e inspiração do tema deste trabalho. Ele o professor Luiz Paulo Fávero foram os responsáveis por me passar as ferramentas para que eu pudesse conduzir a série de testes estatísticos que 
serão apresentados a seguir - lembrando que eventuais erros que possam ter passado são de minha responsabilidade. Não posso deixar de fora também os professores e doutores pela casa Zé Elias, que me deu consultoria de graça sobre alguns aspectos da modelagem usada nesta dissertação, e Nelma Zubek, pelas contribuições na qualificação.

Merecem menção ainda os professores Bruno Salotti, Fernando Murcia, Isabel Lourenço e Lucas Barros, por terem recebido tão bem um jornalista em suas turmas.

É importante deixar claro, contudo, que a grandeza da FEA e da USP não está apenas nos seus professores. Mas também nos seus alunos.

Tive a sorte de entrar numa turma que demonstrou coleguismo, responsabilidade e capacidade acima da média, o que certamente contribuiu para o aproveitamento do conteúdo das disciplinas.

Preciso fazer menção especial a Eduardo Guimarães, que foi minha dupla em parte relevante deste trabalho, quando ele ainda era um artigo de disciplina, e a Eduardo Flores, que também reviu parte dos procedimentos técnicos usados para os testes.

Fabio Silva foi um parceiro para dividir agruras de ser um estranho no ninho da FEA (embora ele menos do que eu) e também por ter me dado o caminho das pedras na reta final do trabalho. Ainda como colegas que merecem ser lembrados estão Thales, Marcus, Diogo, Dênis, Cristiane, Rudah, Catarina, Sara, Alex, Raquel e Verônica (com a certeza de que estou me esquecendo de alguns, seja porque me ajudaram nos grupos dos quais participei, seja porque partilhamos lanches nos corredores da FEA ou cervejas no CA da ECA).

No Valor Econômico, preciso deixar meu obrigado especial a Nelson Niero, meu editor, pela paciência e pela tolerância que teve com as minhas ausências durante todo esse período. Célia Franco e Vera Brandimarte também merecem ser lembradas e agradecidas, por terem me dado o tempo necessário para realizar os estudos.

Por fim, mas certamente não menos importante, agradeço à minha família, a quem dediquei esse trabalho algumas páginas atrás. 
Embora formalmente o título de mestre venha para mim (se der tudo certo na banca), a minha mulher Ticá também merece o dela. Imagino que tenha sido difícil conviver com um marido que não lhe pôde dedicar o tempo e a atenção merecidos. Pior do que isso. Ainda teve que aguentar papo sobre contabilidade e estatística ao longo de todo esse tempo. Mas espero que o investimento feito durante esses dois anos e meio um dia dê à nossa família um retorno tão alto que ela me deixe fazer o doutorado :-). Por isso, registro meu muito obrigado pelo companheirismo que demonstrou durante todo esse período, e em especial nos últimos meses, quando nossa agenda ficou mais "complicada".

Essa complicação veio por um motivo ótimo, com a chegada do nosso querido filho Dudu, que, sem a menor cerimônia, mudou a rotina de todos.

E aqui cabe uma confissão. Ainda que rodar modelos no Stata possa parecer divertido, nada se compara a apertar as bochechas e as pernas gordinhas de um bebê recém-nascido. Até os mais apaixonados por análise de dados e estatísticas hão de concordar comigo quando ouvirem esse bebê falar "papa" pela primeira vez. Filho, valeu por animar o papai para continuar!!!

Minha sogra Babi também me ajudou muito, especialmente nos últimos meses, cuidando do Dudu fora do "expediente", e sem cobrar um centavo de hora extra, e por isso também merece meu agradecimento.

Deixo ainda um muito obrigado ao meu pai, que, embora não tenha vivido tão de perto esse último período da minha jornada acadêmica, será sempre, junto com minha mãe, um dos maiores responsáveis por tudo de bom que eu conseguir fazer nesta vida. Um abraço final também para meus irmãos e parceiros Bernardo e Andrea e para a nova família que eu ganhei nos últimos anos: Jota, Camila, Nunu, Gustavo, Mauro, Jaque e Udo. Valeu pela torcida. 


\section{RESUMO}

Que tipo de relação existe entre a exposição que uma empresa tem na mídia e o seu valor de mercado e o volume de negócios com suas ações? Partindo da premissa que a exposição de uma empresa na imprensa aumenta o alcance das informações relativas a ela e contribui para diminuir a assimetria informacional entre a administração da companhia e os investidores, o objetivo deste trabalho foi testar empiricamente se existe relação positiva entre a exposição de companhias abertas brasileiras na imprensa e seu valor de mercado e a liquidez de suas ações em bolsa. Trata-se do primeiro estudo feito no Brasil sobre o assunto. A partir de uma amostra de 152 companhias que representavam $81 \%$ do valor de mercado da bolsa brasileira em março de 2015, foi levantada a frequência de matérias que citaram essas empresas no jornal Valor Econômico no período de 20 trimestres entre janeiro de 2010 e dezembro de 2014. A técnica estatística usada foi a de regressão com Dados em Painel, que considera a variação tanto entre as companhias da amostra como também as alterações de valores no tempo para cada empresa. Como esperado a partir da plataforma teórica e da evidência de estudos internacionais, os resultados indicam uma relação estatisticamente significativa entre cobertura da mídia e valor de mercado. Os resultados foram consistentes tanto no teste com o múltiplo preço/valor patrimonial (P/VPA) como com a métrica $Q$ de Tobin como variável dependente. Isso significa que, nesta amostra, as empresas que aparecem com mais frequência na imprensa econômica têm maior valor de mercado relativo do que aquelas que aparecem menos. Um terceiro teste foi feito para medir a relação da exposição na mídia com a liquidez das ações, também encontrando associação estatisticamente significante e positiva. No caso do primeiro teste, é importante destacar que, quando a amostra foi dividida em quartis por porte, a cobertura da mídia perdeu significância para explicar o valor de mercado das maiores empresas do país. Espera-se que o trabalho, ainda que com as limitações de um estudo pioneiro no país, possa contribuir para que companhias abertas, assessorias de imprensa, veículos de comunicação e também os reguladores do mercado conheçam melhor as relações existentes com a exposição na imprensa. Se a linha de pesquisa prosperar e uma relação de causa e efeito for comprovada, imagina-se que no futuro as empresas poderão usar planos de mídia em estratégias de relações com investidores e medir esses efeitos.

Palavras-chave: Mercado de capitais; Disclosure; Informação financeira; Imprensa; Jornalismo Econômico; Mídia especializada; Assimetria de informação; Relações com Investidores; Bolsa de valores. 


\begin{abstract}
What kind of relationship exists between the exposure that a company has in the media and its market value and the traded volume of its stocks? Assuming that the exposure of a company in the press increases the extent of information relating to it and helps to reduce the information asymmetry between the company's management and investors, the objective of this study was to empirically test whether there is a positive relationship between Brazilian companies exposure in the press and its market value and the liquidity of its shares on the stock exchange. This is the first study in Brazil on the subject. From a sample of 152 companies representing $81 \%$ of the market capitalization of the Brazilian stock market in March 2015, I have collected the frequency of stories in which they were mentioned in the Valor Economico newspaper in the period of 20 quarters between January 2010 and December 2014. The statistical technique used was the regression with Panel Data, which considers the variation both between the sample of companies as well as value changes over time for each company. As expected from the theoretical platform and evidence from international studies, the results indicated a statistically significant relationship between media coverage and market value. The results were consistent in both the test with the multiple price-to-book $(\mathrm{P} / \mathrm{B})$ as with the Tobin's $\mathrm{Q}$ ratio as the dependent variable. This means that companies in this sample that appear more frequently in the financial press have higher market value relative to those that appear less. A third test was done to measure the relationship between media exposure with the liquidity of the shares, also finding statistically significant positive association. For the first test, it is important to note that, when the sample was divided into quartiles by size, media coverage has lost significance in explaining the market value of the largest companies in the Brazilian market. It is expected that work, albeit with the limitations of a pioneering study in the country, can contribute to public companies, press offices, media outlets and also the market regulators to have a more informed perception of the scope of the exposure in the press. If the line of research to thrive and if a cause and effect relationship is proven, it is thought that, in the future, companies may use media plans in investor relations strategies and measure these effects.
\end{abstract}

Keywords: Capital markets; Disclosure; Financial Information; Press; Business Journalism; Specialized Media; Information Asymmetry; Investor Relations; Stock Exchange. 


\section{SUMÁRIO}

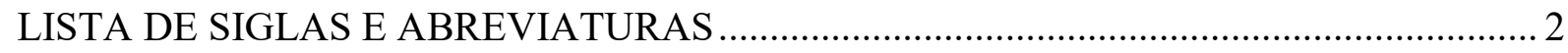

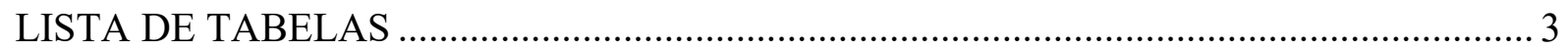

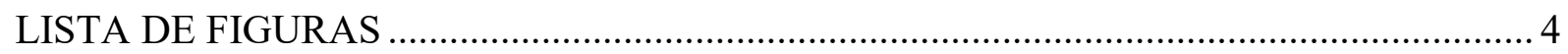

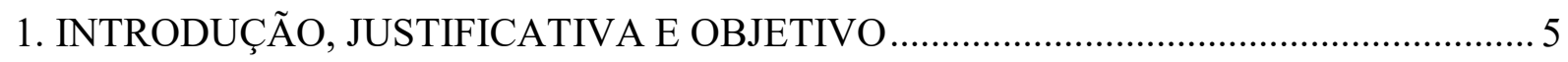

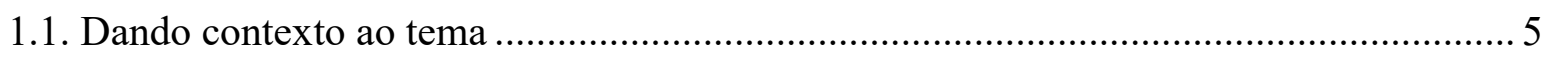

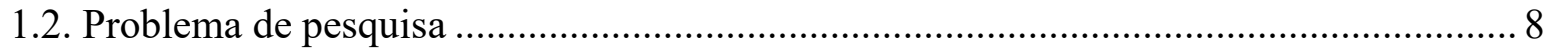

1.3. Base teórica hipótese de pesquisa e objetivo ……………....................................... 10

1.4. Justificativa, descrição metodológica e estrutura do trabalho ......................................... 13

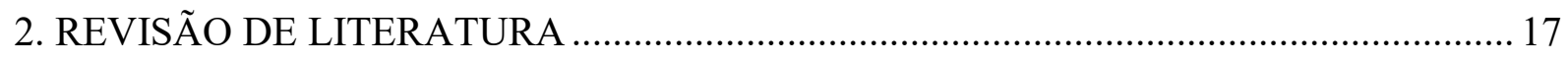

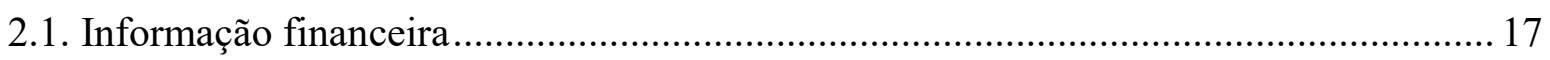

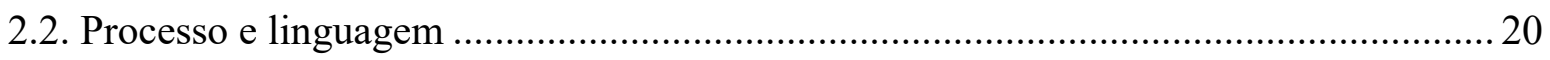

2.2. Ferramentas alternativas de relato financeiro: press releases, teleconferências e

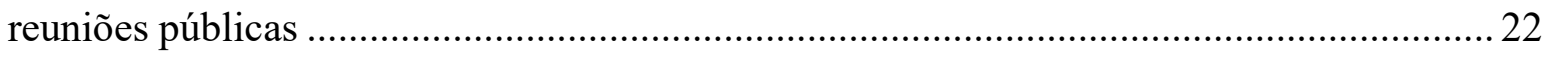

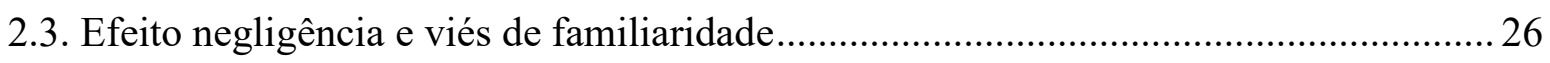

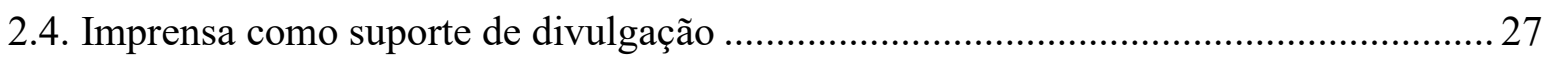

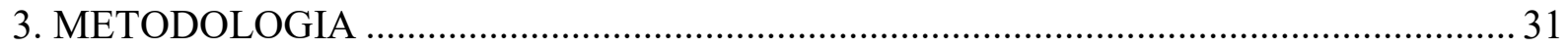

3.1. Definição das características da pesquisa, amostra e coleta de dados.............................. 31

3.2. Definição das variáveis e modelos empíricos.............................................................. 35

3.3. Conexão do constructo teórico com modelo empírico ……………………………….... 49

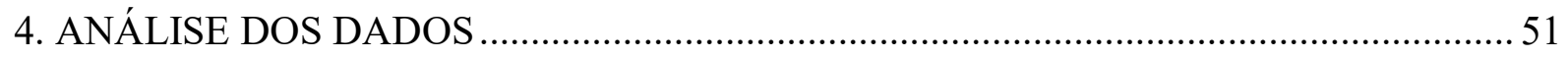

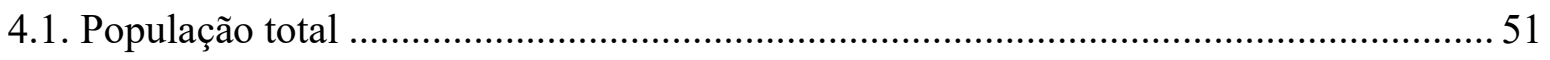

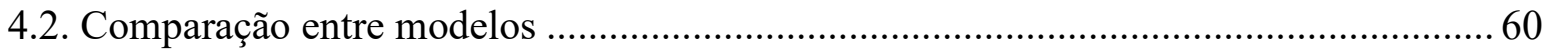

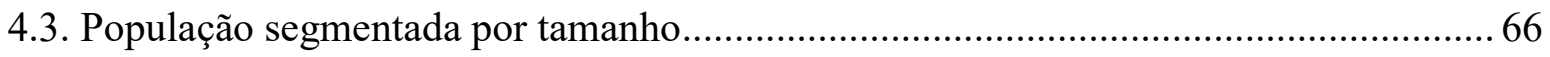

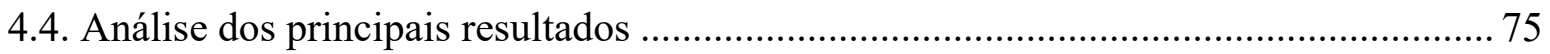

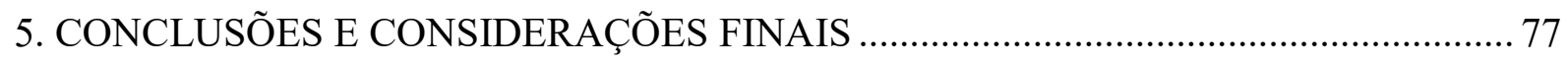

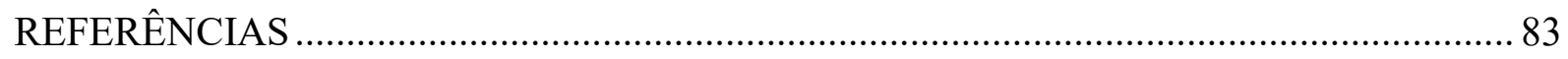




\section{LISTA DE SIGLAS E ABREVIATURAS}

Aberje - Associação Brasileira de Comunicação Empresarial ANJ - Associação Nacional de Jornais

CPC - Comitê de Pronunciamentos Contábeis

CVM - Comissão de Valores Mobiliários

DFC - Demonstração de Fluxos de Caixa

DFP - Demonstrações Financeiras Padronizadas

DMPL - Demonstração de Mutações do Patrimônio Líquido

DRE - Demonstração de Resultados do Exercício

DVA - Demonstração do Valor Adicionado

IAS - International Accounting Standards

Iasb - International Accounting Standards Board

IFRS - International Financial Reporting Standards

IPO - Initial Public Offering

ITR - Documento de informações trimestrais

LN - Logaritmo natural

MD\&A - Management Discussion \& Analysis

P/VPA - Preço / Valor Patrimonial da Ação

SEC - Securities and Exchange Commission 


\section{LISTA DE TABELAS}

Tabela 1. Comparativo entre Lojas Renner e Guararapes................................................... 10

Tabela 2. Lista dos índices de ações considerados para montagem da amostra ...................... 32

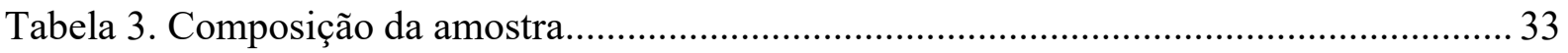

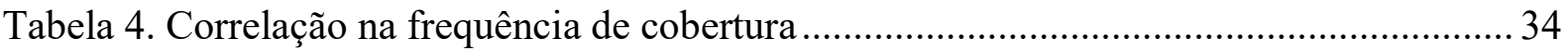

Tabela 5. Lista de empresas pesquisadas, com dados de Publicações ..................................... 36

Tabela 6. Estatística descritiva das variáveis quantitativas ................................................ 45

Tabela 7. Regressão robusta com dados em painel com efeitos fixos, para variável dependente

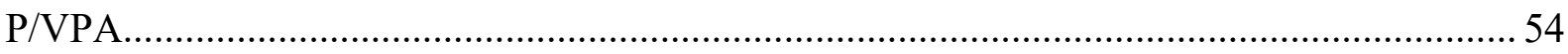

Tabela 8. Regressão robusta com dados em painel com efeitos fixos, para variável dependente

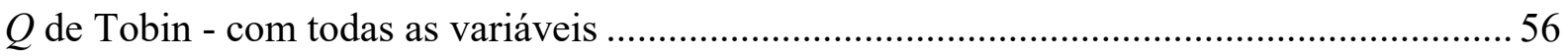

Tabela 9. Regressão robusta com dados em painel com efeitos fixos, para variável dependente

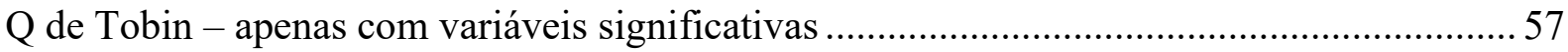

Tabela 10. Regressão robusta com dados em painel com efeitos fixos, para variável

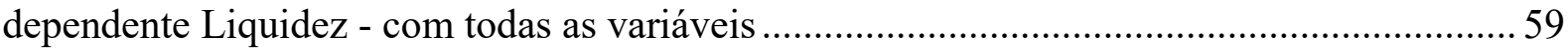

Tabela 11. Regressão robusta com dados em painel com efeitos fixos, para variável

dependente Liquidez - apenas com variáveis significativas.............................................. 60

Tabela 12. Regressão robusta com dados em painel com efeitos fixos, para variável dependente P/VPA - comparação entre modelos

Tabela 13. Regressão robusta com dados em painel com efeitos fixos, para variável dependente $Q$ de Tobin - comparação entre modelos

Tabela 14. Regressão robusta com dados em painel com efeitos fixos, para variável

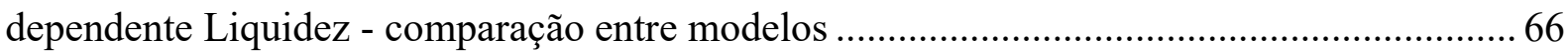

Tabela 15. Matriz de correlação das variáveis da Equação 4 e 6 ........................................... 67

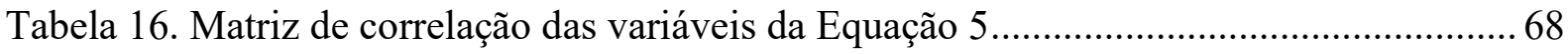

Tabela 17. Empresas segmentadas por quartis, a partir do porte ........................................... 70

Tabela 18. Matriz de correlação das variáveis da Equação 4 e 6, com quebra por porte ........ 71

Tabela 19. Regressão robusta com dados em painel com efeitos fixos, para variável

dependente P/VPA, por quartil de Tamanho, do menor para o maior..... 


\section{LISTA DE FIGURAS}

Figura 1. Gráfico com dados sobre a variável Publicações das empresas

Figura 2. Variável dependente P/VPA com valores originais e após transformação em LN e winsorização.

Figura 3. Variável dependente $Q$ de Tobin com valores originais e após transformação em LN

Figura 4. Variável dependente Liquidez com valores originais e após transformação em LN e

winsorização. 47

Figura 5. Variável de interesse Publicações com valores originais e após transformação em

LN

Figura 6. Variável de controle Crescimento com valores originais e após winsorização........ 47

Figura 7. Variável de controle Retorno com valores originais e após winsorização ................ 48

Figura 8. Variável de controle Tamanho com valores originais e após transformação em LN e

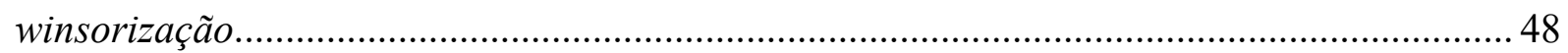

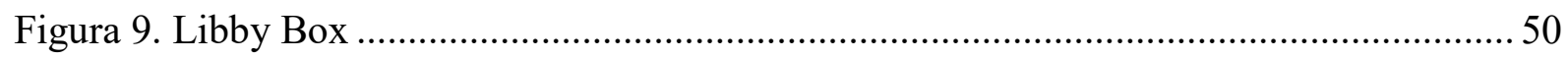

Figura 10. Gráfico de correlação entre P/VPA e Publicações.................................................... 52

Figura 11. Gráfico de correlação entre Q de Tobin e Publicações............................................. 55

Figura 12. Gráfico de correlação entre Liquidez e Publicações ...............................................58

Figura 13. Comparação da correlação entre P/VPA e Publicações, por porte ........................... 72

Figura 14. Correlação entre P/VPA e Publicações, três primeiros quartis................................ 73 


\subsection{INTRODUÇÃO, JUSTIFICATIVA E OBJETIVO}

\subsection{Dando contexto ao tema}

Qual a relação entre a exposição que uma empresa tem na mídia econômica especializada e o seu valor de mercado e a liquidez de suas ações? A partir do pressuposto teórico de que a cobertura da imprensa pode ser um vetor de redução da assimetria de informação sobre companhias abertas, o objetivo deste trabalho é testar se existe relação estatisticamente significante entre esses fatores.

Como plataforma teórica, é usada a Teoria da Firma, estudada por diversos autores ao longo da história, entre os quais se destacam Jensen e Meckling (2008); a Teoria da Divulgação estudada por Verrecchia (1983); o efeito negligência descrito por Arbel, Carvell e Strebel (1983) e por Merton (1987); e o viés de familiaridade, que é um entre os diversos vieses identificados na literatura que trata de finanças comportamentais. Servem de suporte também uma série de trabalhos publicados em revistas internacionais de renome que identificaram uma relação positiva entre publicações na imprensa e o mercado de capitais (Stice, 1991; Pollock \& Rindova, 2003; Tetlock, 2007; Fang \& Peress, 2009; Engelberg \& Parsons, 2011).

Existem diversas evidências práticas de que as empresas de capital aberto dedicam bastante atenção e recursos para cuidar de sua imagem perante seus públicos de interesse (stakeholders). A definição de stakeholders abarca não apenas os "investidores", subcategoria que engloba acionistas e credores - existentes e potenciais -, analistas de ações e analistas de crédito, mas também clientes, fornecedores, empregados da empresa, o setor público, membros da comunidade local onde atuam etc. (Aberje, 2012).

Para se comunicar com os investidores, as companhias de capital aberto mantêm equipes e estruturas dedicadas ao relacionamento direto com eles. A existência de um diretor estatutário

formal e legalmente responsável pelas "Relações com Investidores" é inclusive um requerimento dos reguladores do mercado de capitais, papel que no Brasil é exercido pela Comissão de Valores Mobiliários (CVM).

Mas esse não é o único canal usado pelas empresas para comunicação com os públicos de interesse. Elas também procuram gerenciar seu nível de exposição - do ponto de vista quantitativo e qualitativo - na mídia especializada em negócios e investimentos, que 
normalmente tem potencial para alcançar uma audiência maior e mais abrangente de gestores de recursos, analistas e investidores individuais.

O uso de pelo menos esses dois canais de comunicação fica claro quando da publicação de resultados financeiros trimestrais, uma das obrigações periódicas de divulgação de informação exigidas pela Instrução $n^{\circ} 480$ da CVM. Algumas das maiores empresas do país, como Banco do Brasil, Itaú, Bradesco, Petrobras, Vale, Ambev, BRF e Fibria fazem teleconferências para comentar seus resultados trimestrais de forma regular tanto com analistas e investidores como também com profissionais de imprensa, sendo que em alguns casos a conversa com os jornalistas precede a comunicação direta com os acionistas minoritários e analistas de mercado.

Em ambos os casos, uma prática bem conduzida de comunicação com esses interlocutores tende a reduzir a assimetria informacional existente entre a empresa e seu público investidor, da mesma forma que uma baixa eficácia nessa estratégia de comunicação tem efeito contrário.

Órgãos reguladores como CVM e BM\&FBovespa (na condição de supervisora de mercado) também demonstram interesse especial sobre o potencial impacto que a divulgação de informações corporativas na mídia exerce sobre o mercado de capitais. Não fosse isso, não haveria o "período de silêncio" obrigatório quando da realização de ofertas públicas de valores mobiliários, reguladas pela Instrução $n^{\circ} 400$ da CVM, vedando a manifestação na mídia por parte dos administradores da empresa emissora e executivos de bancos que coordenam a venda dos papéis durante esse período, com receio de que eles queiram promover indevidamente a operação (normalmente sem a devida ponderação sobre os fatores de risco), a exemplo do que ocorre em outros países.

Se não houvesse essa percepção de relevância sobre o papel da mídia, tampouco haveria pedidos de esclarecimento diários feitos pela CVM e pela BM\&FBovespa sobre informações divulgadas a respeito das empresas de capital aberto em jornais, sites e agências de notícias, para verificar se há uma possível violação da Instrução no 358 da CVM, que orienta como as empresas devem divulgar informações eventuais, tais como fatos relevantes sobre planos estratégicos, fusões e aquisições, projetos de investimento, pagamento de dividendos etc., o que deve ser feito sempre de forma equitativa para os participantes do mercado. Levantamento manual feito pelo autor mostra que as empresas analisadas neste trabalho divulgaram um total de 190 de comunicados no sistema IPE da CVM que foram classificados formalmente como 
esclarecimentos sobre "notícia divulgada na mídia" entre novembro de 2013 (quando essa especificação passou a ser exigida) e dezembro de 2014.

O que os reguladores procuram assegurar quando fazem esses questionamentos é uma isonomia informacional entre os investidores que tiveram ou não acesso àquelas publicações.

Outro sinal de valorização da cobertura da mídia por agentes de mercado de capitais está no fato de a BM\&FBovespa (neste caso como empresa interessada em fomentar o investimento em ações no Brasil) custear há 15 anos um curso de MBA anual sobre informações financeiras para turmas de 30 jornalistas (BM\&FBovespa, 2015). Os objetivos da bolsa de valores brasileira com essa iniciativa são: fomentar a cobertura de temas ligados ao mercado de capitais e, ao mesmo tempo, contribuir para o aprimoramento técnico do conteúdo das matérias e reportagens produzidas pelos jornalistas.

Além de companhias, reguladores e intermediários, neste cenário entram também as firmas especializadas em assessoria de imprensa, que têm como negócio exatamente intermediar relacionamento entre as empresas e a mídia. De acordo com dados da Associação Brasileira de Comunicação Empresarial (Aberje), as assessorias de imprensa do país faturaram R \$ 2 bilhões em 2011, contra apenas R \$ 500 milhões em 2001 (em valores atualizados até 2011), embora não apenas com a clientela corporativa (Kachani, 2012).

Outra pesquisa da Aberje (2012) foi feita com 107 empresas que integram os anuários Maiores e Melhores, da revista Exame, e Valor 1000, editado pelo Valor Econômico, que somavam R \$ 754 bilhões em faturamento e empregavam 600 mil funcionários em 2011. Esse estudo indicou que $91 \%$ delas contratam serviços de comunicação empresarial, sendo que 75\% possuem assessoria de imprensa terceirizada, com as demais atendendo a mídia com equipes internas.

Das 107 empresas pesquisadas, 66\% gastavam até R\$ 5 milhões por ano com comunicação empresarial, 19\% desembolsavam entre R\$ 5 milhões e R $\$ 15$ milhões e 7\% dispendiam entre R\$ 15 milhões e R\$ 30 milhões, restando um grupo equivalente a 8\% da amostra que dedicava mais de $\mathrm{R} \$ 30$ milhões anualmente para o segmento.

São atores relevantes nesse processo também os próprios veículos de comunicação, sejam eles jornais, como Folha de S.Paulo, O Estado de S. Paulo, O Globo, Valor Econômico e DCI, agências de notícia, como Bloomberg, Reuters, Dow Jones, Agência Estado, Valor PRO e Agência Leia (CMA), ou sites especializados em economia, negócios e investimentos, tais 
como Infomoney, Portal Exame, UOL Economia e Arena do Pavini, entre outros, que nem sempre têm a dimensão completa do alcance do seu trabalho no mercado.

\subsection{Problema de pesquisa}

Mas será que a mídia é realmente importante e essa atenção dispensada se justifica? O valor que as empresas abertas pagam para sustentar suas equipes de comunicação (sejam internas ou externas) e o tempo que executivos dedicam a entrevistas para jornalistas e ao acompanhamento do que é publicado sobre suas empresas em veículos de mídia estão sendo bem empregados? Quando uma empresa busca uma exposição relevante e positiva na mídia ela tem apenas interesses comerciais (imaginando que ganha visibilidade perante clientes e fornecedores) e de gerenciamento de imagem com stakeholders como empregados, comunidade e setor público, ou também busca atingir os investidores? Em caso positivo, qual o efeito dessa estratégia? Em um projeto de uma companhia aberta que envolva aumentar o valor de mercado da empresa e a liquidez de suas ações por meio de um melhor relacionamento com investidores, deve ser incluído um plano de mídia? E a preocupação e tempo dedicados pelo regulador, são justificados?

Apesar da atenção dedicada ao tema por empresas, intermediários e reguladores, a literatura nacional investigada para a realização deste trabalho não permite que se encontre respostas para essas perguntas. Na pesquisa para essa dissertação, não foi encontrado nenhum trabalho que tratasse da relação da mídia com o mercado de capitais no Brasil. No exterior, o tema começou a ser estudado mais de perto no início da década de 1990, com as publicações se tornando mais frequentes nos últimos anos, como será detalhado no Capítulo 2, que traz a revisão de literatura.

O fato é que, no Brasil e no mundo, a mídia especializada em economia traz diariamente inúmeras matérias sobre empresas de capital aberto cujas ações são negociadas em bolsa. Uma parte das citações de companhias brasileiras se explica pela reprodução de divulgações de informações feitas pela própria empresa - fatos relevantes, balanços trimestrais e comunicados ao mercado, por exemplo - , que são exigidas das companhias abertas reguladas pela CVM, ao cumprir o que é requerido nas leis 6.385/76 e 6.404/76. 
Um dos papéis desempenhados pela imprensa é exatamente esse, o de propagar divulgações obrigatórias feitas pelas companhias, como quando elas anunciam uma aquisição ou seu resultado trimestral, por exemplo. Mas como a base de dados levantada para esse trabalho vai evidenciar, a frequência de citações de empresas em matérias jornalísticas é muito superior à quantidade de divulgações oficiais feita pelas companhias por meio do sistema da CVM. Enquanto a média de divulgação de fatos relevantes é de menos de um por trimestre ( 0,985 , para ser preciso) entre as 152 empresas analisadas para esse trabalho, a frequência média de citações em apenas um veículo de comunicação alcança 24 por trimestre.

O que explica essa diferença é que algumas empresas - umas mais do que as outras procuram a imprensa, por meio de suas assessorias internas ou externas, para fazer outros tipos de divulgação, como lançamento de produtos e serviços, anúncios de início ou conclusão de investimentos em projetos, informações sobre contratações de executivos, obtenção de prêmios ou reconhecimentos públicos por suas práticas de governança corporativa etc. E a literatura inclui no conceito de disclosure de uma empresa não apenas a parte de informação que é regulada por lei, mas também a veiculação de toda informação que seja útil para a tomada de decisões pelos stakeholders, o que envolve também a cobertura da imprensa. (Lima, 2007; Healy \& Palepu, 2001).

A exposição de uma empresa na mídia também ocorre a partir da iniciativa dos veículos de comunicação, que seguem seus critérios editoriais para orientar os assuntos de interesse. Seja por ideia própria, de seus editores, ou por sugestão de fontes, os jornalistas procuram as empresas, diretamente ou por meio de suas assessorias de imprensa, para esmiuçar melhor determinado aspecto do balanço, para esclarecer um detalhe de um fato relevante ou comunicado ao mercado, para comentar sobre um movimento mercadológico observado no segmento de atuação da companhia, para repercutir alguma medida em estudo ou posta em prática pelo governo e assim por diante.

Por fim, a citação de uma empresa na mídia também pode decorrer da ação de terceiros, como quando o repórter menciona o comportamento da ação na bolsa em determinado dia ou período, quando conta aos leitores o que um analista de ações escreveu em seu relatório sobre ela, ou informa o que uma consultoria ou pesquisador acadêmico disseram a respeito dela em um estudo sobre um segmento específico. 


\subsection{Base teórica hipótese de pesquisa e objetivo}

Para ilustrar o tipo de efeito que os estudos sobre redução de assimetria informacional procuram explicar, apresenta-se a Tabela 1 abaixo, que expõe semelhanças e diferenças entre indicadores de duas empresas de varejo de vestuário com ações listadas na BM\&FBovespa, que são Lojas Renner e Guararapes, dona da rede de lojas Riachuelo.

Tabela 1. Comparativo entre Lojas Renner e Guararapes

\begin{tabular}{|c|c|c|c|c|c|c|c|c|}
\hline \multirow{2}{*}{$\begin{array}{l}\text { Valores em } \\
\mathrm{R} \$ \text { milhões }\end{array}$} & \multicolumn{4}{|c|}{ Lojas Renner } & \multicolumn{4}{|c|}{ Guararapes - Riachuelo } \\
\hline & 2011 & 2012 & 2013 & Soma & 2011 & 2012 & 2013 & Soma \\
\hline Receita & 3.238 & 3.862 & 4.370 & 11.470 & 3.046 & 3.545 & 4.069 & 10.660 \\
\hline Lucro bruto & 1.842 & 2.228 & 2.502 & 6.572 & 1.747 & 2.071 & 2.417 & 6.235 \\
\hline Lucro operacional & 472 & 559 & 650 & 1.681 & 479 & 504 & 571 & 1.554 \\
\hline Lucro líquido & 336 & 355 & 407 & 1.098 & 363 & 365 & 420 & 1.148 \\
\hline Ebitda & 569 & 691 & 817 & 2.077 & 602 & 653 & 745 & 2.000 \\
\hline Margem Bruta & $57 \%$ & $58 \%$ & $57 \%$ & $57 \%$ & $57 \%$ & $58 \%$ & $59 \%$ & $58 \%$ \\
\hline Mg. Operacional & $15 \%$ & $14 \%$ & $15 \%$ & $15 \%$ & $16 \%$ & $14 \%$ & $14 \%$ & $15 \%$ \\
\hline Margem Líquida & $10 \%$ & $9 \%$ & $9 \%$ & $10 \%$ & $12 \%$ & $10 \%$ & $10 \%$ & $11 \%$ \\
\hline Margem Ebitda & $18 \%$ & $18 \%$ & $19 \%$ & $18 \%$ & $20 \%$ & $18 \%$ & $18 \%$ & $19 \%$ \\
\hline Valor de mercado* & 5.945 & 9.902 & 7.679 & & 4.867 & 7.216 & 6.255 & \\
\hline Preço/lucro* & 17,7 & 30,1 & 22,5 & & 13,4 & 20,1 & 15,5 & \\
\hline Preço/VPA* & 5,6 & 8,4 & 5,8 & & 2,1 & 2,8 & 2,2 & \\
\hline EV/Ebitda* & 10,9 & 17,0 & 12,2 & & 8,5 & 12,1 & 9,3 & \\
\hline Acionistas PF & 5.567 & 4.995 & 3.934 & & 886 & 776 & 739 & \\
\hline \multicolumn{9}{|c|}{$\begin{array}{l}\text { Nota: Margem Bruta: Lucro bruto/receita. Margem Operacional: Lucro operacional/Receita: } \\
\text { Margem Líquida: Lucro Líquido/Receita. Margem Ebitda: Ebitda/Receita. Valor de mercado: Preço } \\
\text { por ação multiplicado pela quantidade de ações emitidas. Preço/Lucro: Valor de Mercado/Lucro } \\
\text { líquido. Preço/VPA: Preço da ação/Valor patrimonial da ação (que é o patrimônio líquido dividido } \\
\text { pela quantidade de ações). EV/Ebitda: Enterprise Value (Valor de mercado mais dívida } \\
\text { líquida)/Ebitda.*Ao fim de dezembro de cada ano. Acionistas PF: Número de pessoas físicas que } \\
\text { possuem ações da empresa. }\end{array}$} \\
\hline
\end{tabular}

Fonte: CVM, BM\&FBovespa e empresas. Elaboração: Autor

Sem entrar a fundo nos detalhes do caso, a ideia com a apresentação deste quadro é mostrar que, a despeito de atuarem no mesmo setor e no mesmo país e de apresentarem dados financeiros bastante próximos em termos de tamanho e crescimento de receita entre 2011 e 2013, bem como de margens bruta, operacional e líquida ao longo dos últimos anos, existe uma diferença muito relevante no valor de mercado das duas companhias, seja em termos absolutos ou em termos relativos, quando se analisa múltiplos que relacionam o valor de mercado com métricas contábeis como lucro ou patrimônio. A Renner também teve ao longo desses três anos 
um acesso bem mais amplo de investidores pessoa física em sua base de acionistas, no total de 3,9 mil indivíduos em abril de 2013, ante 739 da Riachuelo na mesma época, conforme dados divulgados pelas companhias em seus Formulários de Referência arquivados no site da CVM daquele ano.

Esse tipo de fenômeno leva a crer que existem outras variáveis, que não as puramente contábeis e financeiras, que contribuem para a avaliação de uma empresa e para a atração de interesse por parte dos investidores.

Há certo consenso dedutivo, entre profissionais e estudiosos, de que uma melhor evidenciação das informações, que diminua ou quebre essa assimetria, pode trazer benefícios para a empresa (Lima 2007). E a literatura aponta que um desses benefícios é uma melhor avaliação do preço das ações.

Segundo Merton (1987), as variações resultantes do grau de conhecimento do investidor influenciam o preço de equilíbrio da ação. Handa \& Linn (1993) indicam que um investidor atribui maior incerteza a um ativo com baixa informação em relação a outro ativo que contenha maiores informações, conduzindo o ativo com pouco disclosure a baixos preços e pouca demanda, o que aumenta seu custo de capital.

Em linha com a teoria, estudos empíricos já demonstraram que boas práticas de governança corporativa, como a divulgação de informações adicionais às exigidas legalmente, têm efeito tanto no preço das ações (Palepu \& Healy, 1993) como também no custo de capital próprio (Lopes \& Alencar, 2010), no custo de dívida (Lima, 2007) e na liquidez das ações (Silva, 2009). O trabalho de Lima (2013) mostrou ainda que a cobertura de analistas de investimento está entre os fatores que estão positivamente correlacionados com múltiplos maiores das empresas e menor custo de capital.

Outra linha teórica, esta na área de finanças comportamentais, que pode ajudar a entender o comportamento que se pretende estudar neste trabalho, é a que trata de "viés de familiaridade". Diversos estudos, como o de Cao, Han, Hirshleifer e Zhang, (2011), mostram que existe uma maior propensão do indivíduo a comprar aquilo que ele conhece, com uma atribuição de espécie de prêmio de risco para o desconhecido. É comum, portanto, que indivíduos invistam mais em companhias de seu próprio país, que fundos de pensão comprem ações da empresa patrocinadora, que funcionários tenham papéis da empresa empregadora e assim por diante. 
$\mathrm{Na}$ comparação anterior, cabe notar ainda que a Lojas Renner integra o segmento do Novo Mercado da BM\&FBovespa, o mais alto em termos de governança corporativa do mercado brasileiro, enquanto a dona da Riachuelo não está em nenhum nível diferenciado de governança. Além disso, a primeira é acompanhada por 26 analistas de ações enquanto a segunda por apenas cinco, conforme dados das seções de relações com investidores dessas companhias. Esses são alguns fatores que podem ajudar a explicar a diferença de valor de mercado entre as companhias. O que este trabalho pretende testar é se a frequência de cobertura da mídia econômica é um fator adicional, dentro do universo do disclosure, que está relacionado com o valor de mercado e a liquidez das ações. Apenas como referência, entre 2011 e 2013, a Lojas Renner foi citada em 305 matérias do jornal Valor Econômico, enquanto a Riachuelo apareceu 144 vezes.

Diante do contexto apresentado, a hipótese metodológica do trabalho parte da premissa que a exposição da empresa na mídia aumenta o alcance das informações relativas a ela e que tanto as informações financeiras como as estratégicas e de outra natureza podem ajudar a diminuir a assimetria informacional entre a administração da companhia e investidores. Assim, espera-se que a redução dessa assimetria deva permitir uma maior confiança do mercado em negociar os papéis daquela empresa (como evidencia a literatura citada acima), o crescimento da liquidez, uma melhor formação de preço das ações e o aumento do valor de mercado da companhia.

Colocadas de maneira sistematizada, as hipóteses que serão testadas no trabalho são:

Hipótese 1: Existe relação significante e positiva entre a frequência de cobertura de uma empresa na mídia e seu valor de mercado?

Hipótese 2: Existe relação significante e positiva entre a frequência de cobertura de uma empresa na mídia e a liquidez de suas ações?

Diante das hipóteses apresentadas, o objetivo deste trabalho será construir uma série de testes estatísticos que procurem responder essas duas perguntas, apontando se a cobertura da imprensa tem relação de longo prazo estatisticamente significante com o valor de mercado das companhias e/ou o volume de negócios com as ações das empresas. 


\subsection{Justificativa, descrição metodológica e estrutura do trabalho}

A maior parte das pesquisas internacionais que tenta verificar a existência de relação entre a mídia e o mercado de capitais usa o método de estudo de evento para identificar o efeito pontual de notícias no volume e no preço das ações em janelas temporais de um, dois, ou três dias, com exceção do estudo de Fang \& Peress (2009), que fez um corte transversal para comparar retorno. Os trabalhos tentam medir tanto o efeito da presença ou ausência de cobertura como também se existe diferença associada ao viés da matéria publicada, se positivo ou negativo. Em sua maioria, os estudos comprovam empiricamente haver uma associação estatisticamente significante entre cobertura da mídia e o mercado de ações.

Este trabalho traz uma abordagem inovadora. Não apenas pelo fato de se propor a analisar o assunto mídia/mercado de capitais no Brasil, um país emergente, como também pela metodologia, que não segue a linha do estudo de evento, mas sim de regressão com Dados em Painel. De forma diferente do que foi feito na maioria dos estudos, buscou-se apurar se existe uma associação duradoura - além das janelas de curto prazo - , envolvendo a cobertura da mídia, com as empresas mais acompanhadas tendo características diferentes, em termos de preço e liquidez, daquelas que são menos seguidas por jornalistas. Assim, a questão de pesquisa que se coloca é: será que a cobertura da imprensa tem relação de longo prazo com o valor de mercado das companhias e/ou o volume de negócios com as ações das empresas?

Trabalho semelhante foi feito por Lima (2013) para medir a associação entre cobertura de analistas de ações com o valor da firma. No estudo, Lima (2013) usou como referência o número de profissionais de bancos, corretoras e casas de análise que acompanhavam as companhias que integravam o Ibovespa entre os anos de 1997 e 2012 e encontrou resultados que confirmaram uma relação positiva e estatisticamente significante.

Já na imprensa especializada, embora haja repórteres setoristas, não há apenas um jornalista para cobrir cada empresa. Uma matéria que cite a Petrobras, por exemplo, pode ter sido escrita pelo especialista que acompanha a empresa de perto no Rio de Janeiro (RJ), onde fica a sede da empresa, pelo jornalista de Brasília (DF), ao tratar de aspectos políticos envolvendo a companhia estatal, como também pelo profissional que escreve diariamente sobre bolsa de valores, entre outros.

Assim, de forma alternativa, usou-se o critério de frequência de publicações como proxy de acompanhamento pela mídia. Espera-se que uma empresa seguida mais de perto tenha menos 
possibilidade de apresentar surpresas reais para investidores (sejam elas positivas ou negativas), garantindo uma melhor formação de preço e possivelmente uma melhor avaliação de mercado - mesmo em situações negativas - em relação ao que as mesmas companhias teriam sem igual nível de transparência. Ou seja, uma notícia ruim para a empresa seguirá tendo efeito negativo. Mas espera-se que ele seja menor em um cenário em que a empresa conta com a confiança dos investidores do que em um cenário em que essa confiança não existe.

Para a academia, o trabalho é relevante por explorar uma área de fronteira do conhecimento, como é a interface entre finanças e mídia. Embora a realidade demonstre uma relação frequente e quase que cotidiana entre o mundo empresarial/financeiro e os meios de comunicação, as pesquisas não têm dedicado muita atenção ao assunto.

Para a área de finanças, embora sejam frequentes estudos envolvendo redução de assimetria de informação com redução de custo de capital e aumento no valor da empresa, a mensuração do efeito da cobertura da imprensa ainda merece ser mais bem explorada.

Para o mercado, espera-se que ele contribua ao dar uma visão mais embasada para que as empresas de capital aberto possam gerenciar o grau de exposição que desejam ter na mídia, inclusive para avaliar os custos e benefícios associados com a manutenção do relacionamento com a imprensa. Se essa linha de pesquisa prosperar, imagina-se que no futuro as companhias poderão usar planos de mídia em estratégias de relações com investidores e medir esses efeitos. Caso uma relação de causa e efeito seja comprovada no futuro, espera-se ainda a valorização do trabalho de assessorias de imprensa e dos próprios veículos de comunicação.

Para assegurar que houvesse empresas relevantes na amostra, usou-se como base para a população pesquisada todas as companhias que integrassem algum índice de ações calculado pela BM\&FBovespa. Esse critério, que reuniu 152 empresas, fez com que fossem abarcadas pelo trabalho as companhias mais relevantes do mercado local - seja por tamanho de ativos ou valor de mercado -, aquelas com ações mais negociadas, praticamente todas que abriram o capital desde 2001 e também algumas com importância relativa em determinados setores ou segmentos.

Em termos de metodologia, a ferramenta usada foi a de Dados em Painel, que se mostrou adequada à base de dados, uma combinação de corte transversal com série temporal. Em linha com a expectativa e com a teoria, os resultados apontaram associação positiva entre frequência de publicações e valor de mercado e também com liquidez das ações. 
Além desta Introdução, no Capítulo 2 o leitor encontrará a fundamentação teórica e a revisão de literatura sobre o trabalho. Em seguida, no Capítulo 3, será apresentada a metodologia usada para levantamento dos dados e para montagem das equações. No Capítulo 4, são apresentados os resultados e, em seguida, a conclusão e as considerações finais. 


\section{REVISÃO DE LITERATURA}

\subsection{Informação financeira}

A Estrutura Conceitual emitida pelo Comitê de Pronunciamentos Contábeis (CPC), que tem como base a visão do International Accounting Standards Board (Iasb), diz que "o objetivo do relatório contábil-financeiro de propósito geral é fornecer informações contábil-financeiras acerca da entidade que reporta essa informação (reporting entity) que sejam úteis a investidores existentes e em potencial, a credores por empréstimos e a outros credores, quando da tomada decisão ligada ao fornecimento de recursos para a entidade" (CPC - Comitê de Pronunciamentos Contábeis, 2011).

Tendo como base essa definição, que embora não seja a única não difere muito de outras que existem na literatura (Hendriksen \& Van Breda, 1999; Iudícibus, 2006), pode-se dizer que a contabilidade financeira é um meio. Ela existe para cumprir a função de informar seus públicos.

Assim, a informação prestada pela contabilidade é importante, por exemplo, para ajudar os agentes a decidir quando comprar, vender ou manter ações de uma empresa em carteira. Ela também contribui na avaliação do desempenho da administração de uma companhia durante determinado período. Outra função da contabilidade é colaborar na apuração da capacidade financeira da empresa de honrar compromissos com credores. Entidades reguladoras, Fisco e governo, de forma mais ampla, também se interessam pelas informações contábeis. E há inúmeros outros públicos, como clientes, fornecedores, empregados e concorrentes, entre outros, que se beneficiam do relato trazido pelas demonstrações financeiras.

Mas antes mesmo de se entender quais são as funções da contabilidade, há espaço para se questionar por que existe demanda por esse tipo de informação. De acordo com Fields, Lys \& Vincent (2001), se a contabilidade existe e é relevante para tomadores de decisões, como demonstram inúmeros estudos empíricos (Lima, 2011), é porque existem as falhas de mercado que precisam ser corrigidas. E uma delas está ligada à assimetria de informação. Afinal, se todos os interessados conhecessem a realidade da empresa, seria desnecessário elaborar demonstrações contábeis para tentar explicar essa realidade - com as limitações intrínsecas a todo processo de representação, que sempre será imperfeito. 
A divulgação das demonstrações financeiras reduz a diferença entre o nível de conhecimento que o público interno da empresa - notadamente sua alta administração - tem sobre a situação financeira e patrimonial da companhia em relação ao público externo.

A Teoria da Firma, que fala sobre a separação entre propriedade e controle (gestão), cumpre um papel relevante para explicar esse contexto. Segundo Jensen e Meckling (2008), a existência da contabilidade reduz o custo de agência da relação entre os financiadores e a administração da companhia. Com informações contábeis mais bem fundamentadas, por exemplo, é possível se criar um modelo de incentivos que tente minimizar o inevitável e sempre presente desalinhamento de percepções e objetivos entre as duas partes - agente e principal.

Mas o que leva as empresas a divulgar ao público externo informações além das mínimas exigidas pela legislação? Partindo da premissa de que a transparência implica custo, Verrecchia (1983) estudou os incentivos de se divulgar ou não determinada informação. Segundo o autor, a administração da empresa busca um ponto de equilíbrio entre manter informações sob sigilo e divulgá-las. De um lado, interesses estratégicos e concorrenciais justificariam a não divulgação da informação. De outro, os agentes de mercado podem punir a falta de informações com desconto no preço das ações da companhia, o que acaba estimulando os administradores da empresa a serem mais transparentes sobre a gestão.

A existência de diferentes públicos interessados na informação contábil acaba fazendo com que, em determinadas circunstâncias histórico-culturais, ela seja representada com o enfoque maior em um ou outro público. Como explicam Fields et al (2001), a escolha contábil tende a se moldar a esse ambiente.

Segundo Martins, Diniz, \& Miranda (2012), em jurisdições em que os principais financiadores das empresas são os bancos, as escolhas contábeis tendem a ser mais conservadoras, atrasando o reconhecimento de receitas e acelerando o registro de despesas. Por outro lado, se o agente mais poderoso no financiamento das corporações são os acionistas minoritários, as escolhas contábeis tendem a favorecer esse público. Se o Fisco é o principal público alvo, as decisões serão outras, provavelmente no sentido de se diminuir o resultado tributável. Se o interessado maior for a alta administração da própria empresa, as escolhas estarão voltadas para os itens que determinam ou não o pagamento de bônus aos executivos.

Assim, embora a realidade que se tenta representar por meio das demonstrações financeiras seja a mesma, a escolha contábil permite que se adote vieses distintos nesse processo 
de representação. No caso da Estrutura Conceitual do Iasb, optou-se por dar foco especial aos interesses de acionistas e credores.

Se essas características conjunturais e culturais contribuem para definir a própria base conceitual da contabilidade, imagina-se que o mesmo vale para o suporte e a ferramenta que serão usados para colocar em prática o processo de comunicação das informações financeiras. A constatação da realidade mostra que, para públicos diferentes, distintos meios e estratégias de divulgação são usados, conforme cada um se encaixa melhor na função que pretende cumprir.

Embora a literatura seja extensa ao tratar a contabilidade como ferramenta de comunicação sobre a situação financeira e patrimonial das empresas, a pesquisa realizada para este trabalho identificou que os estudos sobre contabilidade no Brasil costumam se concentrar nas Demonstrações Financeiras Completas divulgadas pelas companhias (seja no formato físico ou eletrônico), que são aquelas que trazem todas as peças contábeis: Balanço Patrimonial, Demonstração de Resultados do Exercício (DRE), Demonstração de Mutações do Patrimônio Líquido (DMPL), Demonstração de Fluxos de Caixa (DFC) e Demonstração do Valor Adicionado (DVA) - esta última exigida legalmente apenas para as companhias abertas -, além das notas explicativas e relatório de administração.

Mas cabe ressaltar que as demonstrações financeiras formais são apenas a ferramenta mais conhecida e tradicional pela qual o contador traduz e apresenta as informações financeiras e corporativas para os usuários. Como diz o eminente professor Nelson Carvalho, da Faculdade de Economia, Administração e Contabilidade (FEA) da Universidade de São Paulo, em suas aulas e também citado por Iudícibus (2013), "accounting follows economics". Assim, o objeto mais importante é a informação financeira em si, e não a ferramenta ou o suporte específico usado para apresentá-la.

Apesar da sutileza, não parece ter sido por acaso que houve a mudança de nome das normas emitidas pelo Iasb de International Accounting Standards (IAS) para International Financial Reporting Standards (IFRS). O termo "relato financeiro" (tradução livre de financial reporting) é mais abrangente que "contabilidade" (accounting). E de alguma forma a troca dos nomes sugere que é possível reduzir a assimetria de informação usando ferramentas diferentes que não apenas por meio do uso de uma conta em forma de "T", com débito e crédito. 
A observação do comportamento das empresas no Brasil e no mundo mostra que existem diferentes suportes ou canais por meio dos quais públicos distintos "consomem" informação financeira e corporativa sobre determinada empresa, como por meio de press releases (que apesar do nome são destinados a investidores e analistas), teleconferências, reuniões públicas de gestores da empresa com investidores, relatórios produzidos por analistas de corretoras e analistas de crédito e matérias jornalísticas.

Para realização desse estudo, que terá como alvo a cobertura da imprensa especializada sobre informações das companhias abertas brasileiras, foi necessário primeiro averiguar o que a academia tem escrito a respeito de ferramentas alternativas de divulgação de informação financeira, por meio de uma revisão da literatura para identificar os principais artigos e estudos acadêmicos que abordaram esses assuntos.

Por meio das plataformas ProQuest e EBSCO, foram pesquisados, em português e inglês, artigos publicados em periódicos com revisão por pares entre o período de 1990 e 2014, que tratassem de temas como: relação entre mídia, informação contábil e mercado de capitais; press release de divulgação de resultados; apresentação de resultados pro forma (ou ajustados); teleconferências; relatório de administração ou management discussion and analysis - MD\&A; e reuniões públicas (como as da Associação dos Analistas e Profissionais de Investimento do Mercado de Capitais). Foram acessados subsidiariamente também trabalhos que abordassem temas como teoria da comunicação e contabilidade, disclosure voluntário de informações, governança corporativa e viés de familiaridade.

A partir da leitura de títulos, palavras-chave e resumos, levantou-se mais de cem artigos ou publicações de alguma forma ligados ao tema. Após um segundo processo de seleção, avaliou-se mais profundamente um subgrupo de 35 de artigos, cuja revisão daqueles mais ligados ao tema do trabalho será apresentada na seção a seguir.

\subsection{Processo e linguagem}

A divulgação de informações pelas corporações depende de inúmeros fatores, entre os quais se destaca não apenas o evento/assunto a ser relatado, mas também a existência de estruturas internas e/ou externas ligadas a isso, como área de comunicação, relações com investidores ou assessoria de imprensa na empresa, seja ela própria ou terceirizada. A divulgação também envolve ritualismo (um processo interno que se impõe e burocratiza a 
divulgação) e oportunismo (Gibbins, Richardson, \& Watherhouse, 1990). Com base em entrevistas, surveys e focus groups com 11 altos executivos de empresas (entre presidentes, diretores financeiros, chefes de controladoria) e nove representantes de usuários de informações, os autores identificaram que entram na análise sobre a divulgação o formato, o conteúdo, a redundância (ou o número de meios em que a mesma informação será divulgada), o timing (momento) e a interpretação prévia e futura que aquela divulgação pode gerar.

Não existe no Brasil uma literatura convergente a respeito dos determinantes de divulgação voluntária de informaçoes. Silva \& Magalhães Filho (2005) identificaram, por exemplo, que existe associação entre porte e retorno menores com divulgação de informações financeiras voluntárias na internet. Já Luz, Camargos \& Lima (2006) fizeram estudo com 40 empresas brasileiras e notaram relação positiva entre divulgação voluntária de informações na internet e porte, retorno acionário e retorno sobre o ativo, mas negativa com retorno sobre o patrimônio.

Desde a década de 1970, alguns trabalhos se dedicam a estudar a contabilidade sob a abordagem da teoria da semiótica ou teoria da comunicação (Gouveia, 2010). A primeira tem ligação com o estudo dos signos (que incluem não apenas a linguagem, como também outras representações como gráficos, tabelas, imagens etc., seus significantes e significados), desenvolvida principalmente por Saussure (19--). A segunda trata do processo de transmissão da informação - emissor, mensagem, receptor, canal, código -, como nos trabalhos de Jakobson (2003). Normalmente, os temas ou questões de pesquisa estão ligados à compreensão da informação contábil pelo usuário, seja de forma ampla, da mensagem principal, ou de termos específicos usados no jargão contábil.

Gouveia (2010) fez uma importante e recente revisão de literatura sobre a pesquisa brasileira a respeito desse assunto, e identificou 18 trabalhos no país envolvendo contabilidade e as teorias de comunicação e semiótica, sendo o primeiro datado de 1994 e os demais todos publicados em periódicos ou apresentados em congressos depois do ano 2000 - o que significa que é uma área de trabalho ainda recente no país. O autor conseguiu identificar seis temas diferentes estudados. Em cinco casos apareceu a categoria que ele chamou de "teóricos", que são trabalhos que sugerem ou propõem o uso das duas teorias, ou de uma delas, para auxiliar no processo de comunicação contábil. Em outra categoria, outros três artigos tratavam da compreensão de termos técnicos pelo usuário da informação contábil. Um deles é o trabalho de Dias Filho \& Nakagawa (2001), que identifica dois tipos clássicos de problemas nos termos 
usados. Um é mais evidente, e ocorre quando o próprio nome é desconhecido da população, como é o caso do termo goodwill - o ágio por expectativa de rentabilidade futura -, e dos agora aposentados "ativo diferido" e "resultados de exercícios futuros". Mas existe ruído de comunicação também com termos que são usados com outros significados fora do ambiente contábil, como depreciação, reserva e até mesmo investimento (que no balanço reflete a participação societária em investidas, mas que para usuários pode se confundir com despesas de capital).

Em um terceiro subgrupo do trabalho de Gouveia (2010) apareceram outros três estudos que investigaram a compreensão de documentos, sendo que foram objeto de análise tanto relatórios de informações contábeis propriamente ditas como um que tratou de laudo pericial. Numa quarta categoria, com quatro trabalhos identificados, pesquisou-se sobre a fidedignidade das informações apresentadas nos relatórios de administração, e se elas estavam de acordo seja em termos numéricos ou no tom - com o resultado apresentado nas peças contábeis. Embora o autor não tenha usado esse nome para rotular a categoria, os trabalhos tratam de forma direta ou indireta da linha de pesquisa conhecida como gerenciamento de impressão ou gerenciamento de imagem. No exterior, como apresentaremos a seguir, essa literatura é bem trabalhada, com análise não apenas da linguagem usada em relatórios de administração e press releases, mas também na ênfase que se dá para cada tipo de informação.

Já com apenas um único representante, uma categoria foi chamada de "influência no preço das ações", que teve como referência um trabalho que analisou se a linguagem usada nos fatos relevantes influenciava o preço das ações. A categoria "evolução de significados", também com apenas um trabalho, trouxe um estudo sobre a mudança dos conceitos tributo e tributação ao longo do tempo.

Como se nota, 18 é um número reduzido de trabalhos sobre o assunto em mais de dez anos, o que mostra que há bastante espaço para se avançar em pesquisas nessa área.

As metodologias usadas foram principalmente de survey e também de análise de conteúdo, técnica usada para se estudar e analisar a comunicação de forma objetiva e sistemática.

\subsection{Ferramentas alternativas de relato financeiro: press releases,} teleconferências e reuniões públicas 
$\mathrm{Na}$ área de ferramentas ou suportes alternativos de divulgação de informação contábil, destaca-se o trabalho de Frankel, Johnson \& Skinner (1999), a respeito das teleconferências, que são eventos voluntários em que normalmente a alta administração de uma companhia convida investidores e analistas para apresentar e detalhar, via ligação telefônica com inúmeros interlocutores, informações a respeito de determinado assunto, na maior parte dos casos as informações financeiras recém-divulgadas. O trabalho teve como base 1.056 teleconferências realizadas no período de fevereiro a novembro de 1995 , sendo que em $85 \%$ dos casos o motivo era a apresentação dos resultados trimestrais, que haviam sido divulgados horas antes (normalmente na noite anterior ou na manhã do mesmo dia). Os autores compararam, então, o volume de negócios intradiário com as ações das empresas durante as teleconferências com o número de transações realizadas com os papéis das mesmas companhias em um período do mesmo dia que não fosse concomitante com o evento, e também com empresas que não fizeram esse tipo de comunicação voluntária. A conclusão do estudo foi que, no intervalo de 75 minutos referente ao período da teleconferência (15 minutos antes da hora marcada para o início e 60 minutos depois), o volume de transações foi estatisticamente maior do que o giro identificado horas antes, já depois do registro do efeito da reação à própria divulgação do balanço, que foi capturado logo na abertura do mercado. Em resumo, o volume de negócios ficou acima da média no início dos negócios, reagindo aos dados trimestrais, recuou à normalidade um tempo depois, e voltou a subir de forma significativa no momento da teleconferência, o que permitiu aos autores inferir que, não tendo identificado outro motivo aparente, os investidores já naquela época, em 1995, negociavam em tempo real a partir das informações divulgadas nesses "encontros telefônicos".

Cabe destacar que nesses eventos os executivos das empresas não apenas apresentam os dados do balanço trimestral recém-divulgado, mas dão uma visão qualitativa e prospectiva acerca do desempenho do negócio, que atrai interesse dos interlocutores que de outra forma não participariam dos eventos.

Em estudo feito por Griffin, Hirschey \& Kelly (2012), foi constatado que os principais gatilhos para divulgação de novos relatórios de analistas não são informações financeiras históricas, mas projeções, estratégias e ambiente de negócios. Talvez isso explique o interesse de investidores nas teleconferências, já que nesses eventos essas perspectivas são transmitidas pela alta administração das companhias. 
Uma evidência contrária à relevância das ferramentas alternativas de comunicação financeira veio de uma análise sobre o impacto das reuniões Apimec, em que as empresas recebem analistas e investidores na sede da associação ou em espaços de eventos, como salas de hotéis, para falar sobre seus números financeiros e estratégias. Um estudo de evento realizado por Reiter \& Procianoy (2012) não identificou relação relevante dessas reuniões com o preço das ações no mercado, ao contrário de evidência internacional. O trabalho analisou mais de 700 reuniões, de quase 200 empresas, no período de 2005 a 2009.

Apesar de os autores terem captado retorno anormal em D+2, ou dois dias após o evento, ele era pequeno e se revertia em seguida. A conclusão do trabalho é que as reuniões serviriam para relacionamento de longo prazo, e não para novidades, talvez por influência da regulamentação, que exige divulgação de dados novos por meio do site da Comissão de Valores Mobiliários (CVM). Mas cabe ressaltar que o estudo tentou capturar o retorno anormal das ações, e não o volume, e nem eventuais consequências de mais longo prazo envolvendo a cobertura de analistas, por exemplo.

$\mathrm{Na}$ linha de ferramentas de divulgação de informação financeira, o press release divulgado não apenas para a imprensa (como diz o nome), mas também para analistas e investidores, é um instrumento bastante difundido, com uso por dois terços das companhias abertas brasileiras, conforme levantamento realizado pelo autor a partir de amostra aleatória com 128 empresas no site da CVM para os resultados referentes ao ano de 2012. E não apenas a própria ferramenta, que tem características próprias de tamanho (média de 28,5 páginas e mediana de 25 páginas) e diagramação que facilitam a leitura em comparação com as demonstrações financeiras (estas bem maiores, com média de 104,7 páginas e mediana de 102 páginas, e com menos recursos gráficos), mas também o conteúdo que lá se coloca são objetos de estudo principalmente no exterior.

Cabe ressaltar que os press releases não são documentos auditados, embora os números contábeis lá divulgados passem por revisão dos auditores que podem vetar alguma incongruência relevante. Há, portanto, mais liberdade sobre o que divulgar nos documentos.

É no press release que aparece o lucro ajustado ou pro forma, que difere daquele calculado de acordo com os princípios contábeis amplamente aceitos. Lougee \& Marquardt (2004) mostram que empresas com lucro contábil (de acordo com o padrão US Gaap) baixo são as que mais usam lucro pro forma, por exemplo. Em trabalho mais recente, Brown, Christensen \& Elliot (2012) identificaram relação positiva entre divulgação antecipada de release (em maior 
número de dias), em comparação à data da divulgação do balanço oficial (esse atraso entre as datas é comum nos EUA), com ajustes e reconciliação de pior qualidade em lucro pro forma.

Elshafie, Yen \& Yu (2010) mostraram que a divulgação de resultado pro forma agressivo (assim classificado quando ele era melhor que o resultado de acordo com as normas contábeis) é associada a ocasiões em que as empresas não batem as projeções e também com tipos de companhias que contam com menos alternativas para gerenciar resultado.

Já Bowen, Davis \& Matsumoto (2005) dizem que a ênfase maior ou menor dada pelas empresas ao resultado pro forma ou contábil no press release é determinada pela métrica mais relevante (ou aquela que está mais associada com o comportamento das ações). Ainda segundo os autores, empresas com grande cobertura de mídia dão mais ênfase ao pro forma em seus press releases, embora eles não explorem os motivos disso.

Por meio de um experimento, Elliot (2004) verificou que analistas dão mais valor para informação pro forma quando aparece a reconciliação detalhada e é possível ver os ajustes que estão sendo feitos. Já os usuários não especialistas se confundem com os dados pro forma, atribuindo um valor maior para a mesma empresa caso ela divulgue o resultado pro forma acima do contábil, com mais destaque e sem reconciliação.

O experimento foi feito com pouco mais de 90 alunos de MBA, que foram tratados como investidores não profissionais, e 55 analistas de ações, que foram os profissionais. Todos foram então submetidos a três apresentações de resultados. O lucro em Gaap com maior evidencia no press release, o resultado pro forma com maior evidencia no press release (mas sem reconciliação pronta, embora fosse possível calculá-la) e o resultado pro forma com maior evidência e reconciliação pronta. Foi neste último caso que os analistas confiaram mais no resultado pro forma, que apontava números melhores, atribuindo valor maior à empresa. Quando o resultado pro forma foi divulgado sem a reconciliação eles não reagiram de forma diferente em relação ao primeiro caso, em que o lucro contábil apareceu com maior proeminência. Já para os não profissionais, o segundo cenário (com resultado pro forma maior e sem reconciliação) levou a uma atribuição maior de valor para a empresa, havendo uma correção para baixo após a apresentação da reconciliação.

Indo mais no detalhe, Davis, Piger \& Sedor (2012) chegaram à conclusão de que é possível notar relevância até mesmo na linguagem usada pelas empresas no press release, seja ela positiva ou negativa. Portanto, não seriam apenas os números, pro forma ou não, que dão 
relevância a esse tipo de documento. Com base em 23 mil press releases divulgados entre 1998 e 2003, eles usaram um software chamado Diction para contar palavras otimistas e pessimistas nos documentos. Os autores conseguiram mostrar uma associação da linguagem com o Retorno sobre Ativos (ROA) futuro da companhia, mesmo incluindo controles específicos como resultados acima da previsão do mercado e a divulgação de projeções (guidance) de resultados futuros na mesma data do press release.

Em outro trabalho que teve como ponto de partida a mesma base, Davis \& Tama-Sweet (2012) conseguiram mostrar que o press release tem menos linguagem pessimista que o MD\&A, sendo que este último é mais exposto à regulação, dado que é divulgado no conjunto das demonstrações financeiras enviadas pelas empresas americanas à Securities and Exchange Commission (SEC). Para o estudo, eles usaram 16,9 mil press releases e outros tantos relatórios de MD\&A sobre os mesmos trimestres. Eles concluíram que a diferença no nível de pessimismo em dois documentos divulgados com propósitos semelhantes e na mesma data seria um indicativo de gerenciamento de impressão por parte das empresas. Notou-se ainda que o otimismo no press release fica ainda maior comparativamente ao do MD\&A quando haveria mais incentivo para isso, que foi considerado o caso de quando as empresas batiam exatamente as estimativas de consenso de mercado, ou as superavam com pouca folga.

Também numa análise sobre linguagem em MD\&A, Blouin (2010) mostra, por meio de uma ferramenta chamada de fog index (que tem por objetivo medir quão complicado é um texto), que empresas com maior risco de litígio têm um relatório de MD\&A menos inteligível que as demais.

\subsection{Efeito negligência e viés de familiaridade}

Além do aspecto puramente racional, que envolve o custo de se obter mais informações sobre uma empresa, há que se considerar também as imperfeições de mercado, que nem sempre funciona de forma eficiente.

Estudiosos da área de finanças como Arbel et al (1983) e Merton (1987) descreveram, há cerca de 30 anos, o fenômeno que ficou conhecido como Efeito Negligência. Segundo esses autores, mantido tudo mais constante, as ações de companhias menos acompanhadas por analistas de mercado oferecem uma espécie de prêmio de risco, em forma de retorno esperado maior, para os investidores que aceitarem comprar seus papéis, mesmo com um conhecimento menor sobre elas. A existência de empresas mais ou menos acompanhadas também é uma 
realidade na cobertura jornalística, de onde se presume que relação parecida possa ser observada com testes que procurem medir a associação entre a exposição das empresas na mídia e o preço de suas ações.

Antes deles, os psicólogos israelenses Daniel Kahneman e Amos Tversky já vinham desenvolvendo suas teorias sobre finanças comportamentais e mostrando como o ser humano age quando tem que tomar decisões. Um dos comportamentos que essa área de conhecimento se dedicou a estudar nas últimas décadas ficou conhecido como viés de familiaridade.

Cao et al (2011) mostram que as pessoas temem o desconhecido e isso leva a uma propensão de as pessoas comprarem ou investirem naquilo que conhecem e que está mais próximo. Ainda que seja claro que existe um custo para se quebrar a assimetria de informação, estudos mostram que, por vezes, o desconto que se atribui ao valor do desconhecido, como ações de países estrangeiros, é desproporcionalmente maior do que deveria ser, como evidenciam Chan, Covrig e Ng (2005).

Em um estudo mais recente e curioso, O'Connor (2013) mediu até mesmo a relação entre o número de fãs de empresas no Facebook com seu valor de mercado, tendo encontrado relação estatisticamente significativa e positiva entre essas duas variáveis.

\subsection{Imprensa como suporte de divulgação}

Até este momento, analisaram-se ferramentas e suportes alternativos de divulgação de informações financeiras que estão sob o controle da empresa. Mas a partir do momento em que uma informação é divulgada, ela pode ser reprocessada e repassada adiante para públicos diferentes e em outros formatos, fora do controle da companhia, sendo que isso pode ou não atender a seus interesses. No caso da informação financeira, isso costuma ocorrer em relatórios de analistas (que não foram objeto de estudo para este trabalho) ou em matérias jornalísticas, que são divulgados, usualmente, assim que se tem conhecimento dos números.

Um dos primeiros trabalhos a apontar de forma empírica como a divulgação formal do balanço não é a única maneira de passar informação financeira relevante ao mercado foi o artigo de Stice (1991). O autor levantou dados de 342 eventos "empresa-trimestre", durante o período de 1976 a 1985, em que os dados contábeis foram divulgados no veículo americano The Wall Street Journal (WSJ) com no mínimo quatro dias de atraso em relação à data do arquivamento do relatório 10-Q ou 10-K (que no Brasil equivalem ao ITR e à DFP, respectivamente) na 
Securities and Exchange Commission. A técnica usada foi a de estudo de evento. Tendo como base um período de 60 dias, o autor calculou a média de negócios com as ações e comparou com o volume de transações em duas janelas de negócios, de D-3 a D+3. A primeira na data de arquivamento do documento na SEC. E a segunda no dia de divulgação no WSJ. Apesar de parecer estranho para hoje, com a informação circulante em tempo real, naquela época havia casos de diferenças grandes entre essas duas datas. A conclusão foi que o volume de negócios aumentou mais na janela de divulgação no jornal, mesmo que atrasada, comparativamente à divulgação oficial.

Em outro estudo de referência sobre relação entre informações financeiras na imprensa e o mercado de capitais, Tetlock (2007) identificou que uma linguagem negativa anormal em uma coluna diária do WSJ sobre mercado permite prever baixa do mercado de ações no dia da publicação, com posterior reversão aos fundamentos nos cinco dias seguintes. De acordo com o autor, não fossem os custos de transação, seria possível arbitrar e ganhar dinheiro com essa constatação. Ele verificou também que um nível de pessimismo ou otimismo anormal em relação à média histórica está associado ao volume. O trabalho de Tetlock (2007) foi feito com uso de um software (General Inquirer) que classificou as palavras como pessimistas de acordo com um dicionário de psicologia de Harvard. Foram usadas colunas diárias dos anos de 1984 a 1998.

Griffin, Hirschey, \& Kelly realizaram um estudo comparando o efeito da publicação de notícias corporativas em 56 países, sendo 26 desenvolvidos e 30 emergentes. Os dados levantados por meio da base Factiva se referiam a 2.593 empresas, gerando 576 mil observações no caso dos países desenvolvidos e 298 mil nos emergentes. O trabalho constatou que os mercados de países desenvolvidos reagem mais em dias com notícias do que sem, com o efeito sendo equivalente, mas menor, nos países emergentes. As hipóteses delineadas pelos autores para explicar a diferença de comportamento entre os grupos de países têm relação com o maior nível de informação privilegiada nas nações em desenvolvimento, o que geraria uma antecipação no volume de negócios (que não ocorreria apenas no dia da notícia) e também com dificuldades nos mecanismos de transmissão de informação nesses países (imprensa especializada menor, por exemplo).

Ainda na área de imprensa, Chan (2002) tomou por base grandes movimentos diários de ações e verificou se havia alguma notícia associada à empresa que pudesse explicar o movimento. E notou que há diferença de comportamento quando existem notícias 
"justificando" a alta ou baixa relevante de um papel, e quando não há essas notícias. No primeiro caso, o autor diz que há uma persistência da variação - ou seja, ela se mantém ao longo do tempo. No segundo, há uma reversão do movimento.

Dyck \& Zingales (2003) notaram também que as ações reagem ao tipo de lucro ao qual a mídia dá ênfase, se o lucro contábil ou o lucro ajustado ou pro forma, divulgado normalmente nos press releases. $\mathrm{O}$ trabalho aponta que o movimento das ações mostra maior associação com o tipo de lucro usado com maior destaque na cobertura da imprensa, seja o contábil ou o ajustado. Ainda segundo o autor, o efeito da imprensa é maior quando há menor cobertura de analistas.

Engelberg \& Parsons (2011) talvez tenham feito o trabalho que mais se aproximou - ou que pelo menos se propôs a fazê-lo - de apontar uma relação causal entre cobertura da mídia sobre uma divulgação de informação financeira e a reação no preço das ações. No estudo de Fang \& Peress (2008), por exemplo, não se observou se os volumes reagiram a partir do conteúdo da novidade trazida pelo jornal, ou pelo simples fato de o meio de comunicação ter escrito sobre aquele fato. Ou seja, no caso de uma matéria sobre uma aquisição de um concorrente, se a reação do mercado foi ao negócio em si, ou ao fato de ter sido publicada a matéria sobre a transação. Da mesma forma, o trabalho de Tetlock (2007) apontou uma associação entre o nível de pessimismo na coluna do WSJ e o desempenho do índice Dow Jones. Em nenhum momento ele sugere que haja uma relação de causa e efeito.

Já Engelberg \& Parsons (2011) tentaram encarar esse desafio. O estudo analisou o comportamento de negócios em 19 regiões diferentes dos EUA e notou relação entre volume de negócios e cobertura da mídia regional sobre resultados financeiros trimestrais. $\mathrm{O}$ trabalho usou uma base de dados no período de 1991 a 2007, envolvendo 15,9 mil investidores de 19 ZIP Codes (equivalente ao CEP brasileiro) diferentes, cujas informações foram fornecidas por uma corretora. $\mathrm{O}$ artigo identificou que existe um viés de localização entre investidores e empresas. Ou seja, há uma relação positiva entre empresas sediadas em determinado local, como Boston, e a base de investidores regionais. Mas, além disso, foi possível notar que o volume de transações com ações de determinada empresa cresce de $8 \%$ a $50 \%$ quando há cobertura da mídia regional. Isso ocorreu tanto quando a empresa tem sede próxima ao ZIP Code dos investidores como no caso contrário. Ou seja, se um jornal de Boston traz matéria sobre o balanço de uma empresa da mesma região, o volume de negócios aumenta naquele ZIP Code. E se a reportagem é sobre uma companhia de outra região, as transações também 
crescem. Para sofisticar ainda mais os controles, os autores avaliaram como era o comportamento em dias que o fuso horário determinasse o atraso na publicação de uma matéria sobre o balanço, ou que tivesse havido grandes tempestades ou nevascas em determinada região, que possivelmente teriam atrasado a entrega dos jornais, e notou-se que, nesses casos, o volume de transações com as ações também respondia com atraso - em vez de subir no dia seguinte ao balanço, só reagia na data de publicação da matéria.

Em outro trabalho que trata de imprensa e informações econômicas, Pollock \& Rindova (2003) mostraram que a cobertura da mídia antes da realização de uma oferta pública inicial de ações (IPO, na sigla em inglês) reduz o underpricing (desconto dado pela empresa vendedora, capturado pela variação positiva da ação no primeiro dia de negociação) e também o turnover (volume de venda ante o total de ações colocadas na oferta) no primeiro dia de negócios. $\mathrm{O}$ trabalho analisou 225 IPOs realizados nos Estados Unidos no ano de 1992, que foi escolhido por ser considerado um ano mediano em termos de volume de operações. Optou-se por usar apenas dados de um ano a fim de evitar que efeitos macroeconômicos ou de conjuntura prejudicassem a análise dos resultados. O trabalho, que cita na sua fundamentação aspectos da teoria institucional e de legitimação, verificou que 83 IPOs do universo observado tiveram cobertura da mídia. E concluiu que essas transações tiveram menos underpricing e turnover no primeiro dia em comparação com as demais. Para evitar uma associação espúria, foram incluídos controles como reputação do banco coordenador líder da operação e também a existência de investimento de private equity na empresa que abriu o capital, já que a literatura mostra que esses fatores poderiam explicar um melhor desempenho de curto prazo em um IPO também.

Usando a frequência de publicações como proxy de cobertura, Fang \& Peress (2009) fizeram um trabalho de corte transversal analisando o retorno anormal das ações da Nyse e da Nasdaq com maior ou menor cobertura da mídia, identificando que as empresas do segundo grupo possuíam um "prêmio", oferecendo retorno maior, pela falta de disclosure.

No Brasil, não foi identificado nenhum trabalho relacionando publicações na imprensa com o comportamento do mercado de capitais, seja com relação de preço de ação ou com volume de negócios. 


\section{METODOLOGIA}

\subsection{Definição das características da pesquisa, amostra e coleta de}

\section{dados}

Neste trabalho usou-se, como mecanismo operacional para mensurar a intensidade ou frequência de acompanhamento da mídia, o número de reportagens publicadas que citam o nome das companhias abertas brasileiras na versão impressa do jornal Valor Econômico, uma joint venture que tem controle compartilhado pelos grupos Globo e Folha. O veículo é o $18^{\circ}$ maior do país entre os jornais diários, segundo dados da Associação Nacional dos Jornais (ANJ) e, entre os 50 de maior circulação auditada, o único com foco principal em economia. A tiragem média ficou em torno de 60 mil exemplares diários durante esse período (ANJ, 2015).

O espaço temporal para a frequência das publicações impressas, utilizada como proxy de exposição/transparência/divulgação, foi o trimestre, isto devido à compatibilização com as variáveis de controle, que são trimestrais, e foram obtidas no sistema da Economatica.

Convém ressaltar um ponto quanto à escolha da utilização das publicações impressas. Tal termo, impressas, não significa que o alcance e penetração das notícias estejam restritos à tiragem média de 60 mil exemplares diários durante esse período. A versão impressa do jornal pode ser vista pelo site www.valor.com.br, que possui visualizações, em bases trimestrais, de visitantes únicos superando 2,5 milhões de pessoas, que podem ou não ser coincidentes com os leitores da versão em papel, já que as senhas de acesso costumam ser compartilhadas dentro de empresas que possuem assinatura.

O levantamento do número de publicações foi feito manualmente considerando os 20 trimestres no período que vai de janeiro de 2010 a dezembro de 2014. Não foram utilizados dados anteriores a 2010, pois a base de dados do site do jornal, por onde foi feita a pesquisa, foi alterada durante o quarto trimestre de 2009. Assim, para garantir resultados consistentes, optou-se por iniciar a coleta a partir das publicações de $1^{\circ}$ de janeiro de 2010.

A população das empresas que entrou na base da pesquisa foi determinada por conveniência. A ideia era assegurar que o trabalho tivesse como base empresas relevantes para os investidores e que, ao mesmo tempo, viabilizassem a pesquisa, já que empresas sem um mínimo de dispersão acionária ou que têm ações muito pouco negociadas prejudicariam a acurácia do cálculo das variáveis dependentes de preço e liquidez em bolsa que foram analisadas no presente trabalho. Ao mesmo tempo, não se quis restringir a pesquisa às empresas 
do Ibovespa, principal índice da bolsa local, para que o numero de companhias não fosse muito reduzido.

Optou-se então por selecionar, como ponto de partida, todas as companhias abertas que, no primeiro quadrimestre de 2015, integravam pelo menos um índice de ações entre os 21 calculados e divulgados regularmente pela BM\&FBovespa, que são divididos em cinco grupos, conforme se vê na Tabela 2.

Tabela 2. Lista dos índices de ações considerados para montagem da amostra

\begin{tabular}{|c|c|}
\hline Grupos de índices & Nome do índice \\
\hline \multirow{4}{*}{ Índices Amplos } & Índice Bovespa - Ibovespa \\
\hline & Índice Brasil 50 - IBrX 50 \\
\hline & Índice Brasil 100 - IBrX 100 \\
\hline & Índice Brasil Amplo - IBrA \\
\hline \multirow{7}{*}{ Índices Setoriais } & Índice BM\&FBOVESPA Energia Elétrica - IEE \\
\hline & Índice BM\&FBOVESPA Industrial - INDX \\
\hline & Índice BM\&FBOVESPA Consumo - ICON \\
\hline & Índice BM\&FBOVESPA Imobiliário - IMOB \\
\hline & Índice BM\&FBOVESPA Financeiro - IFNC \\
\hline & Índice BM\&FBOVESPA Materiais Básicos - IMAT \\
\hline & Índice BM\&FBOVESPA Utilidade Pública - UTIL \\
\hline \multirow{2}{*}{ Índices de Sustentabilidade } & Índice de Sustentabilidade Empresarial - ISE \\
\hline & Índice Carbono Eficiente - ICO2 \\
\hline \multirow{4}{*}{ Índices de Governança } & Índice de Ações com Governança Corporativa Diferenciada - IGCX \\
\hline & Índice Governança Corporativa Trade - IGCT \\
\hline & Índice Governança Corporativa - Novo Mercado - IGC-NM \\
\hline & Índice de Ações com Tag Along Diferenciado - ITAG \\
\hline \multirow{4}{*}{ Índices de Segmento } & Índice BM\&FBOVESPA MidLarge Cap - MLCX \\
\hline & Índice BM\&FBOVESPA Small Cap - SMLL \\
\hline & Índice Valor BM\&FBOVESPA - 2a Linha - IVBX 2 \\
\hline & Índice BM\&FBOVESPA Dividendos - IDIV \\
\hline
\end{tabular}

Fonte: BM\&FBovespa, adaptado pelo autor

Ao se fazer essa busca e o cruzamento entre os diversos índices, chegou-se a 178 companhias. Entretanto, a população foi reduzida logo em seguida por três razões.

O primeiro filtro objetivou retirar holdings pertencentes a cadeias societárias de grupos cuja empresa operacional que representasse substancialmente seus negócios já estivesse 
contemplada na população, como a Metalúrgica Gerdau e a Cosan Ltd, permanecendo Gerdau S.A. e Cosan S.A. Por esse critério, foram retiradas cinco empresas.

O segundo corte buscou eliminar da população empresas com nomes de palavras comumente encontradas em matérias jornalísticas, como nomes de cidades, sobrenomes, variantes de tempos verbais, homônimos, entre outros. Nessa fase foram retiradas as 19 empresas descritas a seguir que trariam ruído na captura dos dados para a análise: ALL, Anima, Panamericano, BM\&FBovespa, Fleury, Gol, Lojas Americanas, Lopes, Natura, Porto Seguro, Positivo, Renova, Rossi, Saraiva, Ser, Telefonica, Tempo, TIM e Vale.

Por fim, Ourofino e Smiles foram retiradas por terem se listado muito recentemente, o que gerava a existência de muitos missing values para as duas companhias.

Tabela 3. Composição da amostra

\begin{tabular}{lc}
\hline Característica & Número de empresas \\
\hline Companhias que integravam algum índice calculado pela & 178 \\
BM\&FBovespa no primeiro quadrimestre de 2015 & $(5)$ \\
Holdings já representadas por empresas operacionais & $(19)$ \\
Nomes que dificultaram busca no site & $(2)$ \\
Empresas com listagem muito recente & 152 \\
Amostra final & \\
\hline
\end{tabular}

Nota: A tabela final com as 152 empresas está no Capítulo 3

Fonte: Autor

Ao fim, portanto, a base da pesquisa teve 152 companhias abertas do país. Juntas, elas tinham valor de mercado de $\mathrm{R} \$ 1,803$ trilhão no fim de marco de 2015 , o que representava $81 \%$ da capitalização total da bolsa brasileira naquela mesma data. Já a soma dos ativos totais das empresas selecionadas alcançava $\mathrm{R} \$ 6,811$ trilhões também ao fim do primeiro trimestre de 2015 , ou $83 \%$ do total das companhias abertas brasileiras com ações listadas. Há que se ressaltar que, por interesse do pesquisador, foram mantidas na amostra as instituições financeiras, já que os grandes bancos do país estão entre as empresas mais acompanhadas pela mídia.

O uso apenas do jornal Valor Econômico como base para pesquisa pode levantar dúvidas e questões sobre a hipótese de se encontrar resultados diferentes se outros veículos também fossem incluídos no trabalho. Caso a metodologia a ser usada fosse de estudo de evento, este seria um problema grave, já que uma ação pode ter retorno anormal como consequência de uma 
informação que foi divulgada em um veículo de imprensa, mas não em outro naquele determinado dia.

Contudo, esse não é um fator de limitação muito relevante quando se analisa a frequência de publicações ao longo dos trimestres, já que os principais jornais tradicionais de grande circulação do país seguem padrão de cobertura com orientação similar. Em outras palavras, se Petrobras, Vale, Itaú e Bradesco estão entre as empresas mais citadas no Valor, assim também ocorre em Folha de S.Paulo, O Estado de S. Paulo e o O Globo.

Fang \& Peress (2009), ao fazerem questionamento similar em seu trabalho realizado nos Estados Unidos, notaram essa redundância de cobertura. Mas para que não haja dúvida de que essa repetição de orientação de veículos concorrentes também existe no Brasil, foram coletados manualmente dados de frequência de citação de 109 do total de 152 de empresas analisadas no estudo, no período de $1^{\circ}$ de janeiro de 2010 a 31 de dezembro de 2014 - sem a quebra por trimestre feita apenas no Valor - tanto no site da Folha de S.Paulo como na página do jornal $O$ Estado de São Paulo na internet. A diferença do número de empresas se explica pela forma como a busca é feita em cada site, o que dificultou o uso do mesmo critério de pesquisa. No sistema de busca da Folha, foi possível selecionar apenas as matérias que saíram na versão impressa do jornal, o que não ocorreu no Estado, o que também compromete a comparação dos números em termos absolutos. Ainda assim, os índices de correlação identificados foram bastante elevados, sempre acima de $90 \%$, e podem ser observados na matriz que aparece na Tabela 4.

Tabela 4. Correlação na frequência de cobertura

\begin{tabular}{|c|c|c|c|}
\hline & Valor & Folha & Estado \\
\hline Valor & 1,0000 & & \\
\hline Folha & 0,9246 & 1,0000 & \\
\hline Estado & 0,9397 & 0,9716 & 1,0000 \\
\hline \multicolumn{4}{|c|}{$\begin{array}{l}\text { Nota: Matriz avalia correlação entre frequência de citação de } \\
\text { empresas nos jornais Valor, Folha e Estado, com base em } \\
\text { pesquisa nos sites. }\end{array}$} \\
\hline \multicolumn{4}{|c|}{ Fonte: Autor } \\
\hline
\end{tabular}

Diante da composição dos números levantados, o meio adequado para o tratamento estatístico é o denominado Dados em Painel, que se demonstra apropriado quando os dados estão distribuídos ao longo de diversos períodos de tempo (Fávero et al, 2009), visto que, nessa 
metodologia, a mesma unidade de corte transversal (uma família, uma empresa, um estado) é acompanhada ao longo do tempo. Em síntese, os Dados em Painel têm uma dimensão espacial e outra temporal (Gujarati, 2006).

No caso deste trabalho, há uma série temporal de 20 trimestres com dados em corte transversal de 152 companhias. Portanto, trata-se de um painel curto, com número de indivíduos maior que o número de períodos, num total máximo de 3.040 observações, mas que na prática se tornam 3.024 para a variável de interesse diante de missing values de empresas que foram constituídas durante o período de análise.

Em uma segunda etapa, após a verificação de alta correlação da variável de interesse "Publicações" com a variável de controle "Tamanho", acima das correlações com as variáveis dependentes, o que é um possível indício de multicolineariedade, utilizou-se a própria variável de controle altamente correlacionada como elemento definidor para segmentar a população em quartis e analisar os grupos individualmente.

\subsection{Definição das variáveis e modelos empíricos}

A relação teórica entre a cobertura da mídia e o valor de mercado das empresas, bem como com a liquidez de suas ações, já foi abordada no capítulo anterior. Do ponto de vista operacional, conforme descrito na Introdução e no item 3.1., a frequência de citações das empresas no jornal Valor foi usada como proxy para mensurar a intensidade de cobertura e/ou exposição da empresa na imprensa. No modelo empírico, essa variável explicativa, que é a variável de interesse do estudo, foi chamada de "Publicações".

Como essa medida é desconhecida da maior parte dos pesquisadores, apresenta-se na Tabela 5 um resumo dos dados que foram levantados, para que se tenha dimensão e familiaridade com eles.

Dentro do que já era esperado, a Petrobras aparece, com folga, como a empresa mais acompanhada pelo Valor, com média trimestral de 445 matérias que citam seu nome pelo menos uma vez. Como mencionado na Introdução, a empresa desperta interesse dos leitores não apenas por seu porte como também por ter extensa base de acionistas pessoa física e, sem dúvida nenhuma, pelo fato de ser uma estatal. 
Tabela 5. Lista de empresas pesquisadas, com quantidade de Publicações

\begin{tabular}{|c|c|c|c|c|}
\hline Empresa & Média trimestral & Mediana & Desvio-padrão & $\begin{array}{c}\text { Total de } 2010 \text { a } \\
2014\end{array}$ \\
\hline Petrobras & 445,5 & 409,0 & 130,6 & 8.909 \\
\hline Itaú & 274,5 & 281,0 & 28,5 & 5.489 \\
\hline Banco do Brasil & 241,7 & 234,5 & 28,7 & 4.834 \\
\hline Bradesco & 235,5 & 233,0 & 34,0 & 4.709 \\
\hline Santander & 212,1 & 209,5 & 29,0 & 4.241 \\
\hline $\mathrm{Oi}$ & 106,5 & 103,5 & 28,3 & 2.130 \\
\hline Eletrobras & 84,0 & 81,5 & 22,0 & 1.680 \\
\hline Pão de Açúcar & 78,8 & 72,0 & 23,4 & 1.576 \\
\hline Gerdau & 72,3 & 75,0 & 11,7 & 1.445 \\
\hline Embraer & 67,8 & 64,0 & 13,1 & 1.356 \\
\hline $\mathrm{JBS}$ & 67,4 & 67,5 & 15,7 & 1.348 \\
\hline CSN & 57,0 & 59,0 & 13,1 & 1.139 \\
\hline Ambev & 55,1 & 53,0 & 11,1 & 1.101 \\
\hline Cemig & 51,7 & 54,5 & 18,0 & 1.034 \\
\hline Usiminas & 49,6 & 51,0 & 9,5 & 991 \\
\hline $\mathrm{BRF}$ & 48,6 & 47,0 & 15,5 & 972 \\
\hline Braskem & 44,8 & 45,0 & 9,6 & 896 \\
\hline Cosan & 40,9 & 40,0 & 11,1 & 817 \\
\hline Suzano & 39,6 & 39,5 & 8,3 & 791 \\
\hline Marfrig & 38,4 & 38,5 & 12,0 & 767 \\
\hline CPFL & 35,1 & 35,5 & 7,7 & 701 \\
\hline Cielo & 34,8 & 35,5 & 11,0 & 695 \\
\hline Iguatemi & 30,9 & 30,0 & 9,2 & 618 \\
\hline Fibria & 30,7 & 33,0 & 8,8 & 613 \\
\hline Sabesp & 27,7 & 25,0 & 11,9 & 554 \\
\hline Sul América & 27,7 & 29,5 & 7,8 & 553 \\
\hline Cesp & 27,0 & 22,5 & 19,1 & 539 \\
\hline CCR & 26,9 & 26,5 & 10,7 & 537 \\
\hline PDG & 26,3 & 24,0 & 9,1 & 526 \\
\hline Cetip & 25,4 & 26,0 & 7,2 & 507 \\
\hline Renner & 25,2 & 24,0 & 6,2 & 504 \\
\hline Eletropaulo & 25,2 & 23,0 & 7,5 & 503 \\
\hline Gafisa & 24,6 & 24,0 & 11,4 & 492 \\
\hline Cyrela & 24,4 & 23,5 & 7,9 & 488 \\
\hline Hypermarcas & 24,4 & 24,0 & 7,9 & 487 \\
\hline Copel & 23,7 & 21,5 & 12,5 & 474 \\
\hline Magazine Luiza & 21,8 & 18,0 & 9,6 & 436 \\
\hline Klabin & 21,4 & 20,5 & 6,5 & 428 \\
\hline MRV & 21,2 & 21,5 & 4,8 & 424 \\
\hline ABC Brasil & 20,8 & 19,0 & 5,6 & 416 \\
\hline Light & 20,7 & 19,0 & 7,6 & 414 \\
\hline Hering & 19,3 & 20,0 & 5,6 & 386 \\
\hline Kroton & 19,3 & 12,0 & 14,6 & 386 \\
\hline
\end{tabular}




\begin{tabular}{|c|c|c|c|c|}
\hline Minerva & 17,2 & 17,0 & 8,5 & 343 \\
\hline Via Varejo & 16,8 & 16,0 & 8,9 & 335 \\
\hline BR Malls & 16,6 & 16,0 & 7,0 & 331 \\
\hline Totvs & 16,4 & 15,0 & 5,9 & 327 \\
\hline Estácio & 15,6 & 12,5 & 8,3 & 312 \\
\hline Ecorodovias & 15,5 & 16,5 & 7,7 & 309 \\
\hline $\mathrm{B} 2 \mathrm{~W}$ & 14,8 & 14,5 & 6,2 & 296 \\
\hline Marisa & 14,3 & 13,5 & 3,9 & 285 \\
\hline Cteep & 13,6 & 8,0 & 16,9 & 272 \\
\hline Ultrapar & 13,3 & 13,0 & 4,8 & 266 \\
\hline BB Seguridade & 12,8 & 0,0 & 18,3 & 256 \\
\hline $\mathrm{HRT}$ & 12,8 & 10,0 & 7,5 & 255 \\
\hline Souza Cruz & 12,7 & 12,5 & 3,8 & 253 \\
\hline Grendene & 12,6 & 12,0 & 4,5 & 252 \\
\hline Randon & 12,5 & 12,5 & 3,6 & 250 \\
\hline Banrisul & 12,4 & 12,0 & 2,5 & 247 \\
\hline Arteris & 12,3 & 11,5 & 6,2 & 246 \\
\hline Dasa & 12,2 & 12,0 & 6,3 & 243 \\
\hline BicBanco & 12,1 & 10,5 & 7,0 & 241 \\
\hline Pine & 12,0 & 12,0 & 5,1 & 239 \\
\hline Tractebel & 11,8 & 11,0 & 5,2 & 236 \\
\hline Multiplan & 11,7 & 12,0 & 3,6 & 234 \\
\hline Marcopolo & 11,3 & 11,0 & 3,3 & 225 \\
\hline Indusval & 11,2 & 9,5 & 6,3 & 223 \\
\hline Weg & 10,4 & 10,0 & 3,3 & 208 \\
\hline Duratex & 10,2 & 9,5 & 3,3 & 204 \\
\hline Santos Brasil & 10,2 & 9,5 & 4,2 & 204 \\
\hline Tarpon & 10,2 & 9,5 & 5,2 & 204 \\
\hline Even & 10,1 & 10,0 & 4,6 & 201 \\
\hline BR Properties & 9,9 & 10,0 & 4,0 & 198 \\
\hline Tecnisa & 9,9 & 10,5 & 4,9 & 197 \\
\hline Alpargatas & 9,8 & 10,0 & 2,4 & 195 \\
\hline Brasil Pharma & 9,8 & 7,5 & 11,8 & 195 \\
\hline Arezzo & 9,6 & 9,0 & 5,5 & 191 \\
\hline Aliansce & 9,5 & 8,0 & 5,1 & 189 \\
\hline São Martinho & 9,3 & 8,5 & 3,7 & 186 \\
\hline CVC & 9,2 & 11,0 & 4,4 & 184 \\
\hline Multiplus & 8,9 & 8,0 & 4,5 & 178 \\
\hline Localiza & 8,8 & 9,0 & 3,3 & 175 \\
\hline Daycoval & 8,7 & 8,0 & 4,4 & 173 \\
\hline AES Tietê & 8,6 & 9,0 & 3,0 & 171 \\
\hline Vanguarda Agro & 8,6 & 7,5 & 4,4 & 171 \\
\hline Qualicorp & 8,0 & 8,0 & 5,1 & 159 \\
\hline Equatorial & 7,9 & 6,0 & 7,1 & 158 \\
\hline Triunfo Participações & 7,9 & 7,0 & 4,3 & 158 \\
\hline EZTec & 7,5 & 8,0 & 2,4 & 149 \\
\hline
\end{tabular}




\begin{tabular}{|c|c|c|c|c|}
\hline JHSF & 7,4 & 7,0 & 3,7 & 148 \\
\hline Raia Drogasil & 7,2 & 7,0 & 2,1 & 144 \\
\hline Biosev & 7,1 & 5,0 & 5,3 & 141 \\
\hline Le Lis Blanc & 6,9 & 5,5 & 3,9 & 138 \\
\hline M. Dias Branco & 6,9 & 6,0 & 4,4 & 138 \\
\hline Tereos & 6,9 & 6,0 & 3,5 & 137 \\
\hline Sonae Sierra & 6,7 & 6,0 & 4,5 & 134 \\
\hline JSL & 6,7 & 6,0 & 3,7 & 133 \\
\hline Abril Educação & 6,5 & 6,0 & 5,3 & 129 \\
\hline Paranapanema & 6,5 & 6,0 & 4,7 & 129 \\
\hline Contax & 6,4 & 6,0 & 3,4 & 128 \\
\hline SLC & 6,2 & 5,5 & 3,6 & 123 \\
\hline Taesa & 6,1 & 6,0 & 4,0 & 122 \\
\hline Energias do Brasil & 5,9 & 5,0 & 4,9 & 117 \\
\hline Celesc & 5,7 & 5,0 & 4,0 & 114 \\
\hline Rodobens & 5,7 & 6,0 & 2,6 & 114 \\
\hline Copasa & 5,7 & 4,0 & 3,4 & 113 \\
\hline Coelce & 5,6 & 6,0 & 3,2 & 112 \\
\hline Sofisa & 5,6 & 5,5 & 3,0 & 112 \\
\hline Odontoprev & 5,5 & 5,5 & 2,2 & 110 \\
\hline Brasil Brokers & 5,4 & 6,0 & 3,0 & 108 \\
\hline Direcional & 5,4 & 5,0 & 2,3 & 107 \\
\hline lochpe & 5,4 & 4,5 & 3,3 & 107 \\
\hline QGEP & 5,1 & 5,0 & 3,8 & 102 \\
\hline BHG & 4,9 & 5,0 & 2,5 & 98 \\
\hline $\operatorname{Lin} x$ & 4,6 & 3,0 & 5,3 & 92 \\
\hline General Shopping & 4,6 & 4,5 & 3,0 & 91 \\
\hline Romi & 4,6 & 3,5 & 3,6 & 91 \\
\hline Magnesita & 4,4 & 4,0 & 4,5 & 87 \\
\hline Helbor & 4,3 & 4,0 & 2,0 & 86 \\
\hline Ideiasnet & 4,3 & 4,0 & 3,4 & 86 \\
\hline Log-In & 4,3 & 3,5 & 2,9 & 86 \\
\hline Trisul & 4,3 & 4,0 & 3,1 & 85 \\
\hline Alupar & 4,2 & 3,5 & 3,7 & 84 \\
\hline Bematech & 4,2 & 5,0 & 2,0 & 84 \\
\hline $\mathrm{CCP}$ & 4,1 & 4,0 & 2,2 & 81 \\
\hline Mills & 4,1 & 4,0 & 3,1 & 81 \\
\hline Eternit & 3,9 & 3,0 & 2,5 & 77 \\
\hline Kepler & 3,9 & 3,5 & 2,0 & 77 \\
\hline Time For Fun & 3,7 & 3,0 & 3,8 & 73 \\
\hline Technos & 3,6 & 2,5 & 2,9 & 72 \\
\hline IMC & 3,6 & 3,0 & 2,4 & 71 \\
\hline Brasil Insurance & 3,4 & 3,0 & 2,4 & 68 \\
\hline Mahle & 3,4 & 3,0 & 2,3 & 67 \\
\hline Paraná Banco & 3,2 & 3,0 & 2,1 & 63 \\
\hline Eucatex & 3,1 & 2,5 & 2,5 & 61 \\
\hline
\end{tabular}




\begin{tabular}{|c|c|c|c|c|}
\hline BrasilAgro & 3,0 & 2,5 & 2,3 & 59 \\
\hline Valid & 3,0 & 3,0 & 1,6 & 59 \\
\hline CSU & 2,9 & 3,0 & 2,1 & 58 \\
\hline Tupy & 2,9 & 2,0 & 2,0 & 58 \\
\hline Heringer & 2,9 & 3,0 & 1,7 & 57 \\
\hline Profarma & 2,9 & 2,5 & 2,0 & 57 \\
\hline Tegma & 2,5 & 2,0 & 1,8 & 50 \\
\hline Fras-le & 2,4 & 2,0 & 1,7 & 47 \\
\hline Locamerica & 2,3 & 1,5 & 2,6 & 46 \\
\hline Unicasa & 2,3 & 1,0 & 2,6 & 46 \\
\hline Metalfrio & 2,2 & 1,5 & 2,6 & 44 \\
\hline São Carlos & 2,2 & 2,0 & 1,5 & 44 \\
\hline CR2 & 1,8 & 2,0 & 1,2 & 36 \\
\hline Portobello & 1,8 & 1,5 & 1,7 & 35 \\
\hline Renar & 1,5 & 1,5 & 0,9 & 30 \\
\hline Ferbasa & 1,3 & 1,0 & 1,3 & 25 \\
\hline Providência & 0,9 & 1,0 & 1,0 & 18 \\
\hline Média & 24,3 & & & 486,3 \\
\hline Mediana & 9,7 & & & 193 \\
\hline Desvio-padrão & 53,1 & & & 1.061 \\
\hline Soma & & & & 73.920 \\
\hline
\end{tabular}

Logo abaixo da Petrobras surgem em bloco os quatro grandes bancos de capital aberto que atuam no mercado de varejo brasileiro. Pela ordem de citações, Itaú, Banco do Brasil, Bradesco e Santander.

Os bancos certamente ganham esse destaque devido à concentração de mercado - há menos concorrentes para citar - e também porque eles têm uma atuação transversal entre os diversos setores da economia, seja fornecendo crédito bancário para as demais empresas, vendendo produtos de investimento à população como um todo, estruturando captações via emissão de ações e títulos de dívida para grandes companhias e assim por diante.

Além disso, eles possuem áreas de pesquisa econômica cujos profissionais aparecem frequentemente como fonte de matérias sobre temas macroeconômicos, apresentando suas projeções para indicadores de inflação, taxa Selic, crescimento do Produto Interno Bruto (PIB) e medidas relacionadas a contas públicas e setor externo. 
Bem abaixo desse primeiro grupo, que reúne Petrobras e grandes bancos, vem a empresa de telefonia Oi e demais empresas não financeiras, como a estatal elétrica Eletrobras, a varejista Pão de Açúcar, a siderúrgica Gerdau e fabricante de aviões Embraer, completando as dez mais citadas. No período da pesquisa, Oi e Pão de Açúcar viveram períodos de conflito societário, o que estimulou a cobertura da imprensa. Eletrobras é uma grande empresa estatal, o que por si só atrai atenção, e foi também protagonista da mudança de regulamentação do setor elétrica promovida pela edição da Medida Provisória 579, no fim de 2012.

A Gerdau teve atenção não apenas por seu porte, mas também por ter seu presidente de conselho e controlador, Jorge Gerdau, atuando como conselheiro do governo durante esse período. Já a Embraer é uma grande exportadora do país, uma antiga estatal, e sempre tem grande exposição.

Na Figura 1, aparece um gráfico que mostra a evolução trimestral das citações das empresas nas matérias do Valor. Embora não seja possível ver os dados da cada companhia, dá para notar que elas têm uma espécie de referência do nível de cobertura da imprensa, com o número de citações variando ao longo do tempo, mas sem mudar completamente de patamar no curto prazo. Esse é um dos motivos para a preferência pelo teste de Dados em Painel na modalidade que considera efeitos fixos, como será descrito no Capítulo 4.

O saldo que algumas linhas dão no quarto trimestre de 2012 se justifica exatamente pela MP 579, citada acima, com as empresas do setor elétrico ganhando cobertura especial por parte da imprensa. No quarto trimestre de 2014, o que explica o salto de citações da Petrobras é a repercussão das investigações de corrupção da Operação Lava Jato.

Cabe notar que, embora se reconheça que seria oportuno fazer também uma avaliação qualitativa sobre o conteúdo das publicações - ou seja, indicar se elas traziam abordagens positivas, neutras ou negativas sobre as empresas, bem como do nível de destaque e proeminência dado para as companhas nas reportagens -, isso não ocorreu por falta de instrumentos automatizados que permitissem a realização da tarefa para mais de 73 mil matérias identificadas no período de cinco anos. 
Figura 1. Gráfico com dados sobre a variável Publicações das empresas

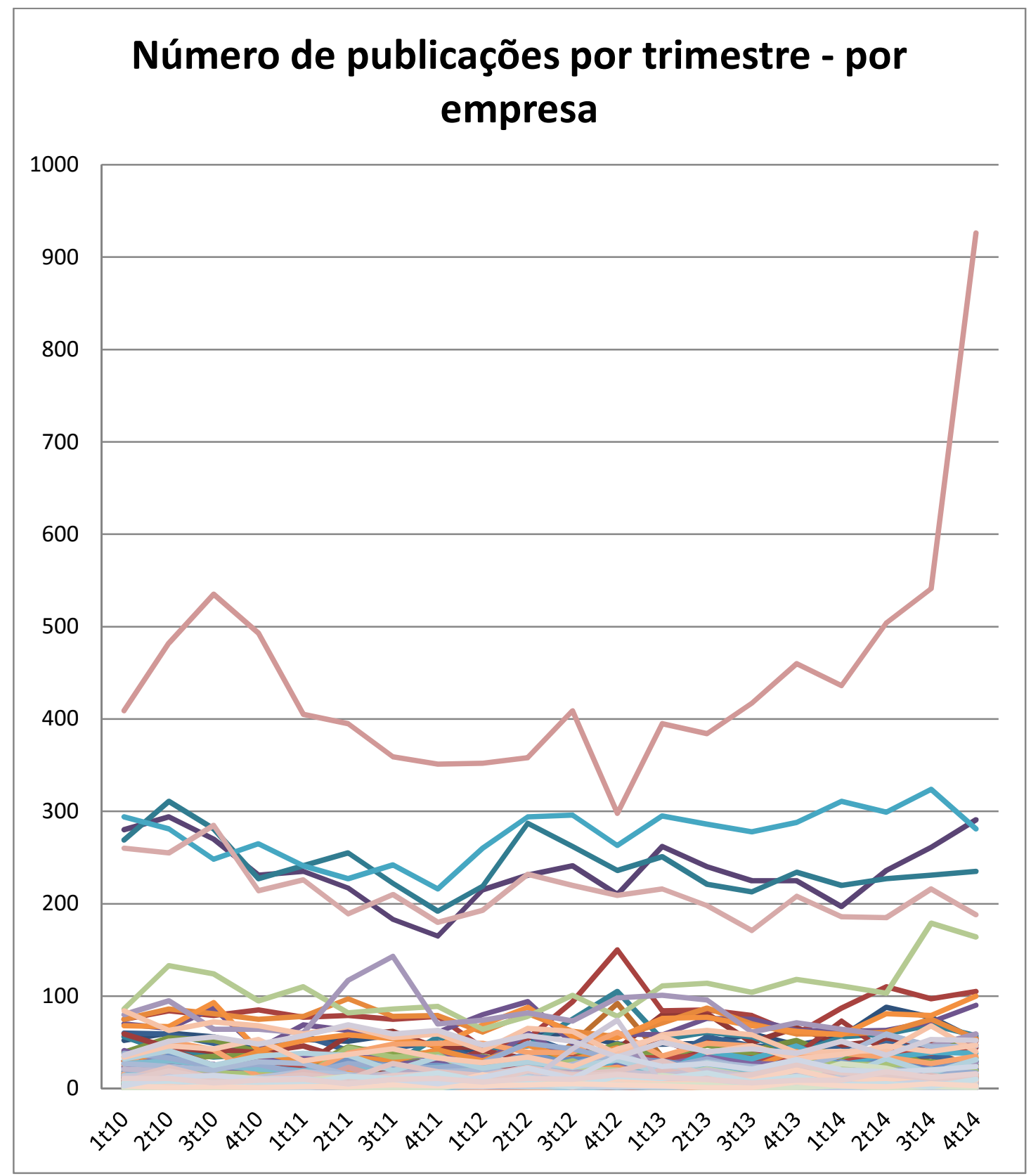

Fonte: Autor

Como variável dependente que indicasse valor de mercado, foram escolhidas duas medidas de avaliação de empresas por múltiplo. A principal delas, que permite que o estudo seja feito com a base completa de 152 empresas, incluindo bancos e seguradoras, mede a relação entre o valor de mercado das ações de uma empresa e seu valor patrimonial e será tratada no estudo como "P/VPA", sigla para preço/valor patrimonial da ação. Em inglês, essa medida é conhecida como price-to-book ratio, ou pela sigla $\mathrm{P} / \mathrm{B}$. 
Alternativamente, para afastar uma possível crítica de viés de seleção da variável dependente, o mesmo teste foi repetido com a variável $Q$ de Tobin como medida de valor de mercado das empresas. Nesse caso, as instituições financeiras ficaram de fora, restando na base de estudo 139 companhias. Famá e Barros (2000) publicaram um estudo detalhado sobre a variável $Q$ de Tobin, que também é um múltiplo que relaciona valor de mercado da empresa com suas métricas contábeis. Para esse estudo, foi usado um dos modos simplificados de cálculo, conforme sugerido pelos autores e como consta da Equação 1 abaixo:

$$
Q \text { de Tobin }=\frac{\text { Valor de mercado }+D}{\text { Ativo total }}
$$

(Equação 1)

Nessa expressão, o valor de mercado é a cotação da ação da empresa multiplicada pelo número de ações emitidas da respectiva classe, seja ordinária ou preferencial, e o ativo total é o valor contábil do ativo da empresa ao fim de cada trimestre. O termo D é definido pela Equação 2:

$$
D=V C P C-V C A C+V C E+V C D L P
$$

(Equação 2)

Em que:

VCPC - é o valor contábil do passivo circulante;

VCAC - é o valor contábil do ativo circulante;

VCE - é o valor contábil dos estoques;

VCDLP - é o valor contábil da dívida financeira de longo prazo.

Nos dois casos, espera-se que empresas mais bem avaliadas tenham múltiplos P/VPA e $Q$ de Tobin acima de 1, indicando que o mercado atribui valor para empresa maior do que seu balanço patrimonial. Nos dois casos, portanto, quanto maior o índice, mais bem avaliada é a companhia. Espera-se que haja uma relação positiva entre cobertura da mídia e esses dois indicadores de valor de mercado.

No segundo modelo empírico, em que se procurou testar a relação da cobertura da mídia com o volume de negócios com ações das respectivas empresas, optou-se pela variável Liquidez em bolsa, calculada pela Economatica e chamada no estudo de "Liquidez". Trata-se de uma medida relativa que leva em conta volume financeiro e quantidade negócios com as ações, sempre em comparação com o total do mercado local. Essa medida, cujo cálculo aparece na 
Equação 3, é bastante semelhante ao indicador usado pela BM\&FBovespa como um dos critérios para inclusão das empresas em seus principais índices de ações, como o Ibovespa.

$$
\text { Liquidez }=100 * \frac{p}{P} * \sqrt{\frac{n}{N} * \frac{v}{V}}
$$

Fonte: Economatica

(Equação 3)

Em que:

p - é o número de dias em que houve pelo menos um negócio com a ação dentro do período;

$\mathbf{P}$ - é o número total de dias do período;

$\mathbf{n}$ - é o número de negócios com a ação dentro do período;

$\mathbf{N}$ - é número de negócios com todas as ações da bolsa no período;

$\mathbf{v}$ - é o volume financeiro negociado com a ação no período;

$\mathbf{V}$ - é o volume financeiro com todas as ações da bolsa no período

Optou-se também por incluir neste estudo diversas variáveis de controle que pudessem estar relacionadas ao valor de mercado e ao nível de liquidez das ações das empresas, a fim de se procurar isolar o poder explicativo da variável de interesse.

Tendo como referência geral inúmeros estudos da área de finanças, entre os quais os de Lima (2013) sobre o efeito da cobertura de analistas e o de Lopes \& Alencar (2010) sobre disclosure e custo de capital, as variáveis utilizadas foram: "Tamanho", "Retorno" (contábil), "Crescimento", "Endividamento", "Nível de Governança Corporativa” da BM\&FBovespa e existência de registro na "SEC".

A variável "Tamanho" foi representada no modelo pelo "ativo total" de cada empresa em milhares de reais ao fim de cada trimestre. A literatura internacional aponta que empresas maiores têm menor risco próprio e, portanto, menor retorno esperado. Isso significa, também na teoria, que uma parte maior de seu valor intrínseco já deva estar refletido no preço de suas ações. Em mercados emergentes, como o Brasil, alguns trabalhos identificam relação positiva entre tamanho e retorno da ação - ao contrário do que ocorre em países desenvolvidos. Esperase ainda que empresas de maior porte tenham valor de ações em circulação maior, o que aumentaria a liquidez dos papéis.

A variável "Retorno" foi calculada com uso do retorno sobre o patrimônio líquido (ROE, na sigla em inglês para Return on Equity), tendo como base o lucro líquido acumulado em 12 meses até o fim do trimestre, dividido pelo patrimônio líquido médio do período. A 
opção pelo ROE, e não pelo retorno sobre ativos, se deve à decisão do pesquisador de manter as instituições financeiras na amostra. Espera-se que empresas mais rentáveis sejam mais bem avaliadas, mais transparentes e atraiam mais investidores para negociar seus papéis.

A variável "Crescimento" foi capturada pela variação da receita líquida em períodos sequenciais de 12 meses, imaginando que empresas com maior crescimento ensejariam maior expectativa de resultados futuros e, portanto, múltiplos maiores. No caso dos bancos, que no padrão contábil brasileiro não divulgam uma linha de receita, foi usada alternativamente a variação da margem de intermediação financeira (receita financeira menos despesa financeira) antes da perda com devedores duvidosos.

Foi incluído ainda, quando possível, o segmento de governança corporativa da BM\&FBovespa que cada empresa segue, já que se espera que empresas com maior nível de transparência e que ofereçam maior garantia aos minoritários possam ser valorizadas por isso. Como se trata de uma variável qualitativa e foram considerados quatro possíveis níveis de governança - Nível Tradicional, Nível 1, Nível 2 e Novo Mercado -, foram criadas três dummies identificando essa classificação. Uma quarta dummy foi usada, ainda numa tentativa de capturar boa governança corporativa, para identificar as empresas que possuem recibos de ações negociados nos Estados Unidos e estão sujeitas à supervisão da SEC. É importante destacar que, por falta de variância para a mesma empresa ao longo do tempo (variância entre ou within), essas variáveis são omitidas quando se roda o modelo de Dados em Painel com efeitos fixos.

Quando a variável dependente foi "Liquidez", foi incluída como controle adicional a variável "Fato Relevante", com o número de documentos divulgados em cada trimestre pelas empresas. A ideia nesse caso foi tentar filtrar um aumento do número de negócios que fosse motivado por divulgações diretas da empresa, independentemente da cobertura jornalística.

Na Tabela 6 são apresentadas as estatísticas descritivas das variáveis quantitativas em seu estado bruto, sem qualquer tipo de modificação. As variáveis dependentes e de controle quantitativas foram obtidas no sistema da Economatica. A variável de interesse "Publicações" foi capturada manualmente no site do Valor e a variável de controle "Fato Relevante" foi levantada também manualmente no site da CVM. 
$\mathrm{Na}$ operacionalização da pesquisa foram realizados alguns ajustes nas variáveis, sendo um deles com o uso da técnica de winsorização ${ }^{l}$, um procedimento para se retirar outliers da amostra. Em outros casos, foi feita também a transformação do dado bruto em seu logaritmo natural (LN). Isso porque as variáveis, além de representarem unidades diversas (quantidade de publicações, ativo em milhares de reais, retorno sendo uma relação, crescimento uma diferença, além do fato relevante), detinham, originalmente, ordens de grandeza muito díspares, em alguns casos exponencial, como pode ser observado na Tabela 6. Assim, o objetivo da transformação foi a linearidade dos parâmetros, que é um dos pressupostos de uma regressão (Gujarati, 2006).

Tabela 6. Estatística descritiva das variáveis quantitativas

\begin{tabular}{|c|c|c|c|c|c|c|c|c|}
\hline \multirow[b]{2}{*}{ Variável } & \multirow[b]{2}{*}{ Observações } & \multirow[b]{2}{*}{ Média } & \multirow{2}{*}{$\begin{array}{l}\text { Desvio- } \\
\text { padrão }\end{array}$} & \multirow[b]{2}{*}{ Mínimo } & \multicolumn{3}{|c|}{ Percentil } & \multirow[b]{2}{*}{ Máximo } \\
\hline & & & & & $1 \%$ & $50 \%$ & $99 \%$ & \\
\hline P/VPA & 2.814 & 2,537 & 3,541 & 0,146 & 0,288 & 1,5515 & 19,389 & 51,787 \\
\hline$Q$ de Tobin & 2.963 & 1,257 & 1,309 & $-0,3810$ & 0,128 & 0,817 & 6,822 & 14,441 \\
\hline Liquidez & 2.832 & 0,4243 & 0,8234 & 0,00004 & 0,0008 & 0,149 & 3,73 & 10,36 \\
\hline Publicações & 3.024 & 24,44 & 54,700 & 0 & 0 & 9 & 288 & 926 \\
\hline Tamanho & 2.965 & 35.706 & 148.740 & 40 & 159 & 4.041 & 908.139 & 1.437 .486 \\
\hline Retorno & 2.856 & 14,9 & 32,0 & $-96,6$ & $-38,5$ & 12,6 & 125,1 & 985,9 \\
\hline Crescimento & 2.780 & 25,4 & 247,9 & $-1.069,3$ & $-46,8$ & 13,0 & 150,1 & 10977,1 \\
\hline Endividamento & 2.966 & 56,1 & 19,8 & 1,3 & 10,9 & 55,9 & 93,2 & 98,8 \\
\hline Fato relevante & 3.024 & 0,99 & 1,362 & 0 & 0 & 1 & 6 & 20 \\
\hline
\end{tabular}

Nota: As variáveis estão na forma bruta, como foram capturadas ou calculadas a partir de dados na Economatica ou levantadas no site do Valor, sem transformação em logaritmo natural ou winsorização. P/VPA é o valor de mercado da empresa dividido pelo seu valor patrimonial; $Q$ de Tobin resulta de cálculo descrito nas equações 1 e 2 do item 3.2 deste trabalho; Liquidez em bolsa tem cálculo descrito na equação 3 do item 3.2 deste trabalho; Publicações é o número de matérias em que cada empresa é citada por trimestre no jornal Valor; Tamanho é o ativo total da empresa em milhões de reais; Retorno é a rentabilidade sobre o patrimônio líquido de cada empresa; Crescimento é a variação da receita em 12 meses; e Endividamento é a razão entre o exigível total e o ativo total da empresa.

Fonte: Autor

Para ilustrar a diferença de distribuição das variáveis em suas unidades originais e com os ajustes realizados, é apresentada abaixo uma sequência de sete figuras com dois histogramas cada uma. O primeiro histograma traz a distribuição da variável na unidade original e o segundo após a transformação para logaritmo natural e/ou a aplicação da winsorização, conforme o ajuste realizado em cada caso. As variáveis dependentes "P/VPA" e "Liquidez" sofreram winsorização e foram levadas a logaritmo, assim como a variável de controle "Tamanho". A variável de interesse "Publicações" foi transformada em logaritmo, mas não foi winsorizada, já

\footnotetext{
${ }^{1}$ A winsorização é um procedimento em que os registros com valores acima ou abaixo de determinados percentis da amostra, superiores ou inferiores, são substituídos pelo maior e menor valor remanescentes do limite estabelecido. Neste trabalho, o corte foi feito em $1 \%$ e $99 \%$.
} 
que o efeito prático seria equivalente a tirar a Petrobras e o Itaú da base do estudo. Como foi feito um teste separado sem grandes empresas, não se considerou necessária essa modificação. A variável dependente " $Q$ de Tobin" foi apenas transformada em logaritmo, enquanto as variáveis de controle "Retorno", "Crescimento" e "Endividamento" passaram somente por winsorização.

Figura 2. Variável dependente P/VPA com valores originais e após transformação em LN e winsorização
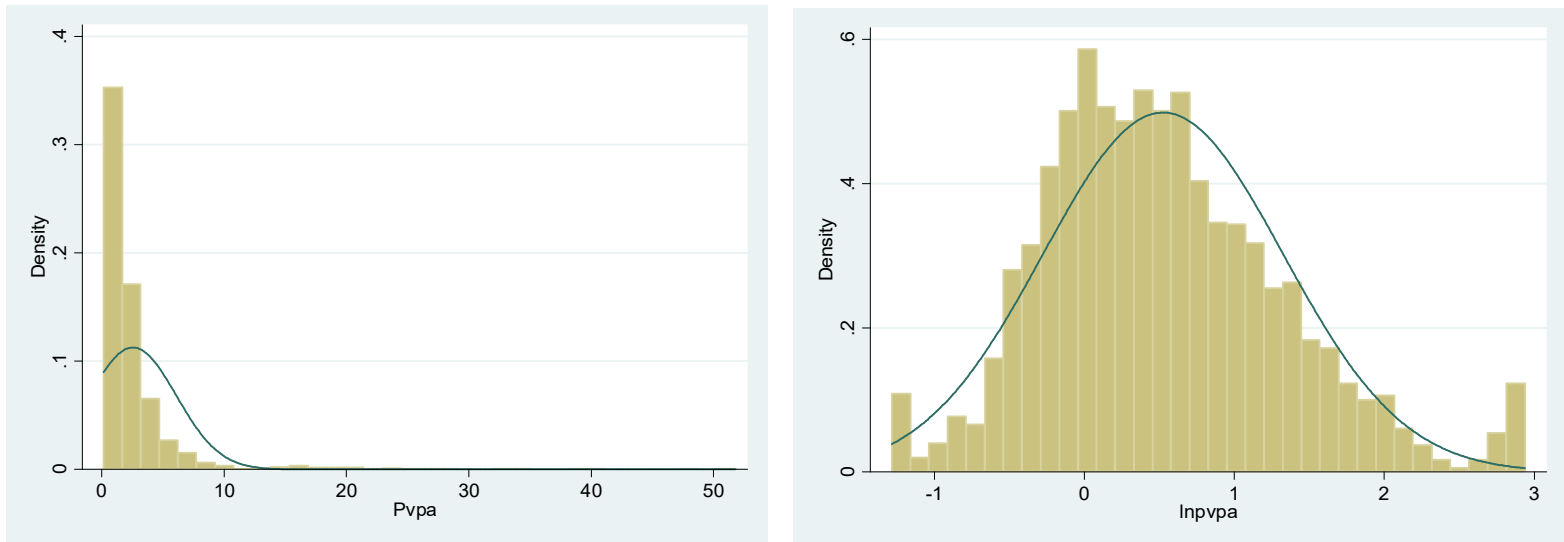

Fonte: Autor

Figura 3. Variável dependente $Q$ de Tobin com valores originais e após transformação em LN
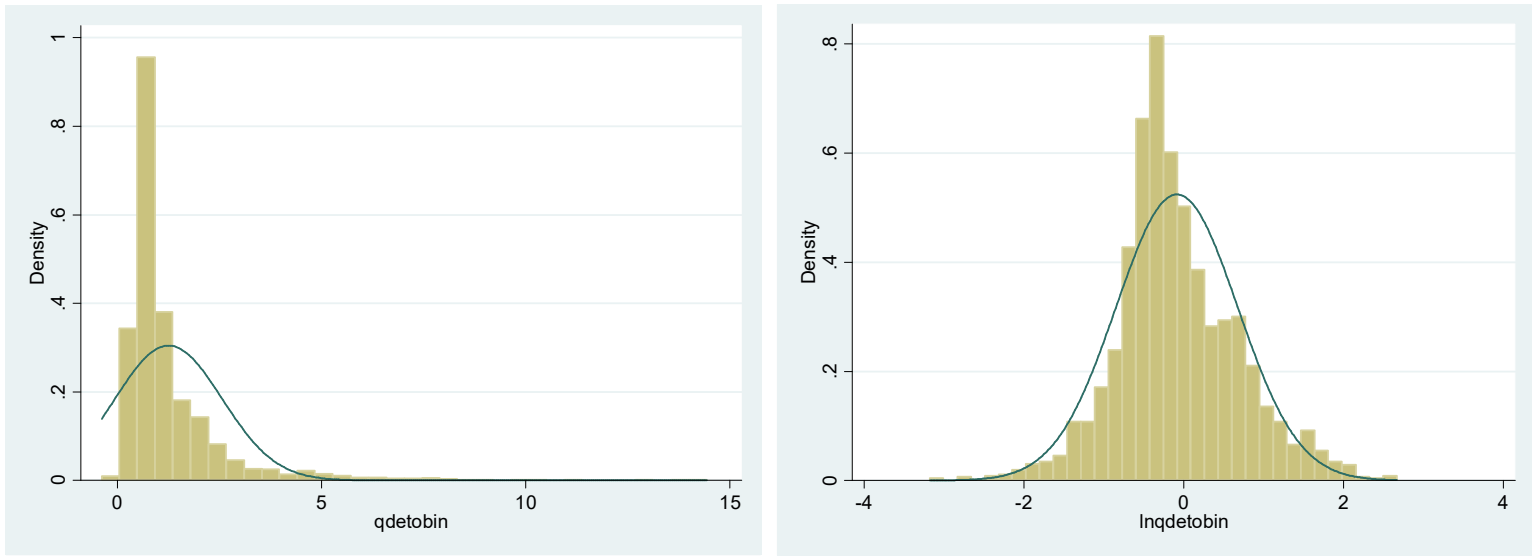

Fonte: Autor 
Figura 4. Variável dependente Liquidez com valores originais e após transformação em LN e winsorização
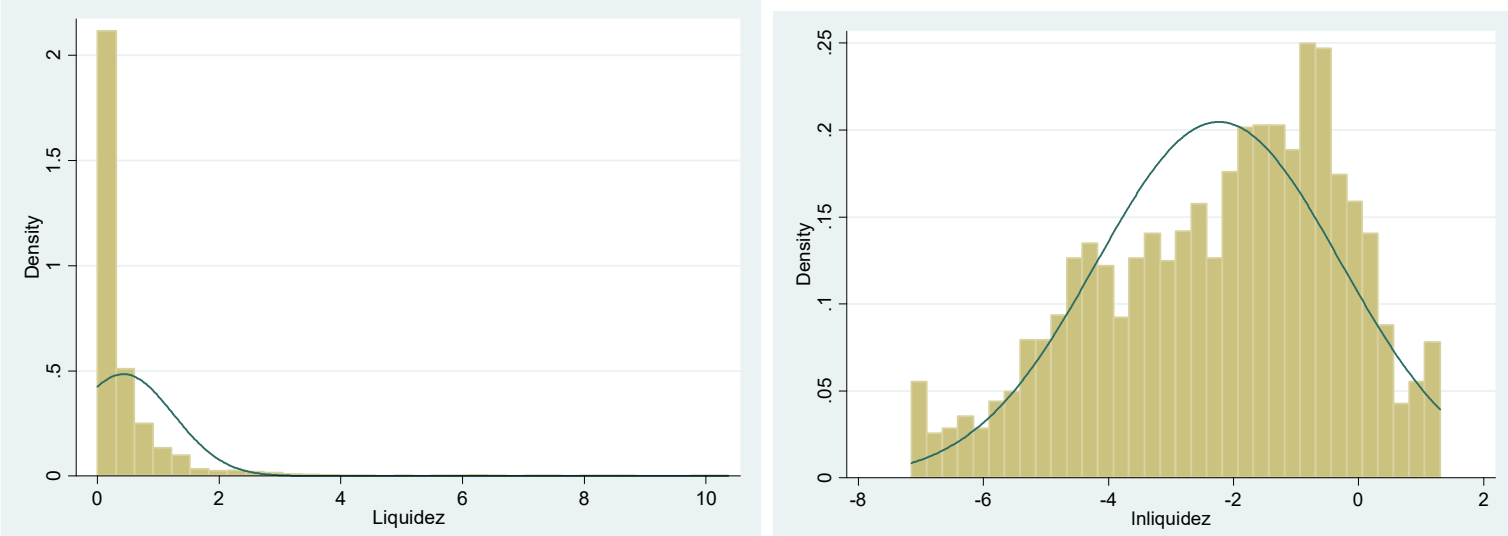

Fonte: Autor

Figura 5. Variável de interesse Publicações com valores originais e após transformação em LN
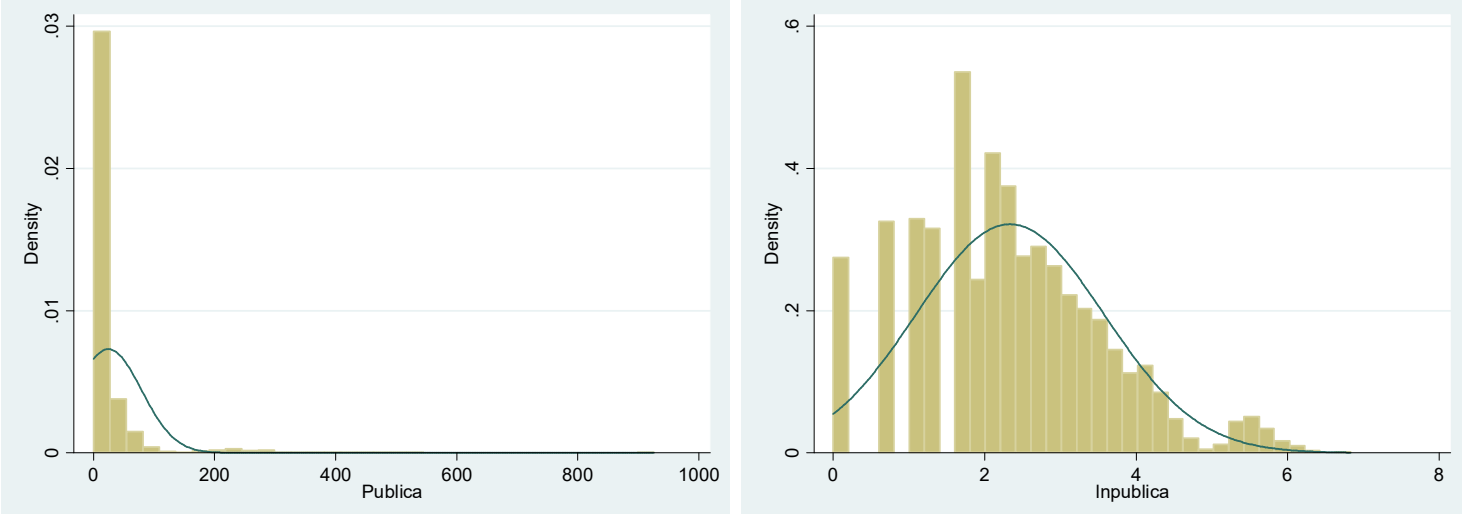

Fonte: Autor

Figura 6. Variável de controle Crescimento com valores originais e após winsorização
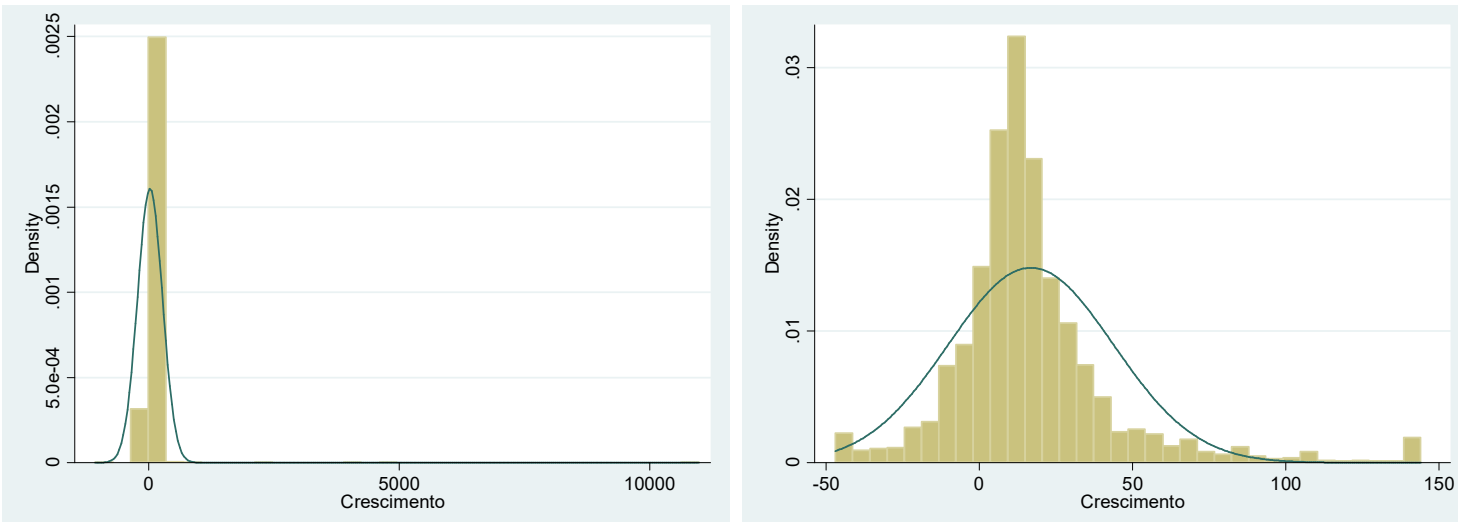

Fonte: Autor 
Figura 7. Variável de controle Retorno com valores originais e após winsorização
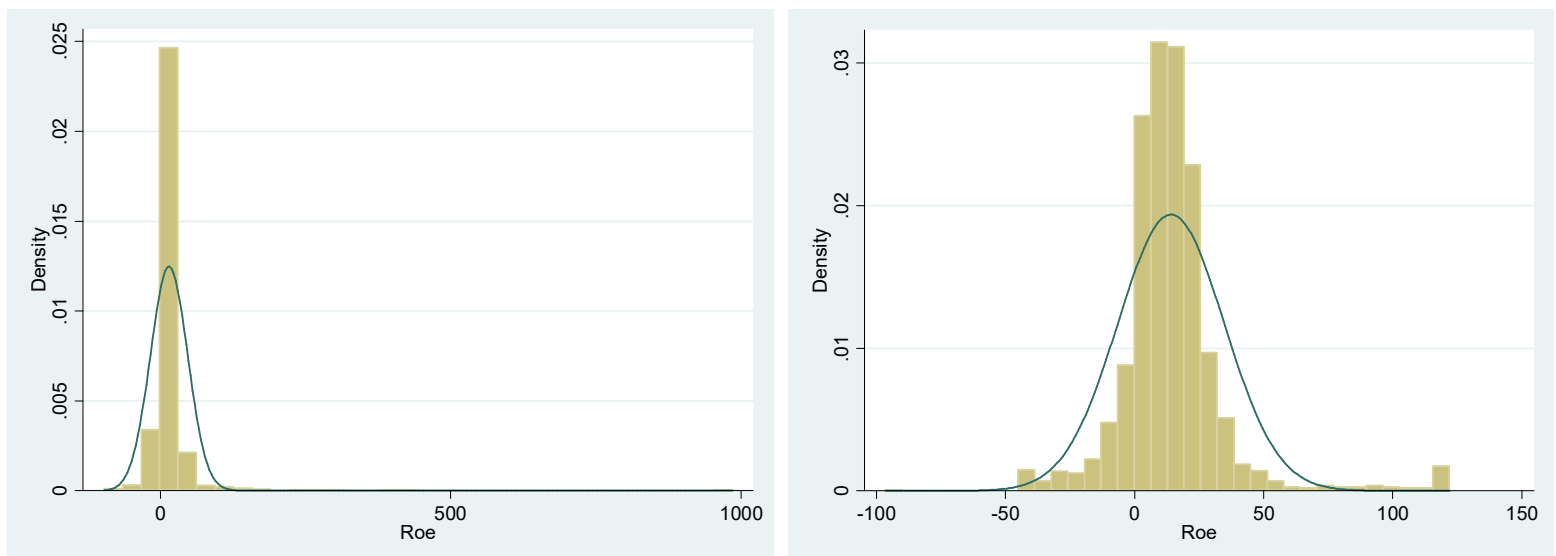

Fonte: Autor

Figura 8. Variável de controle Tamanho com valores originais e após transformação em LN e winsorização
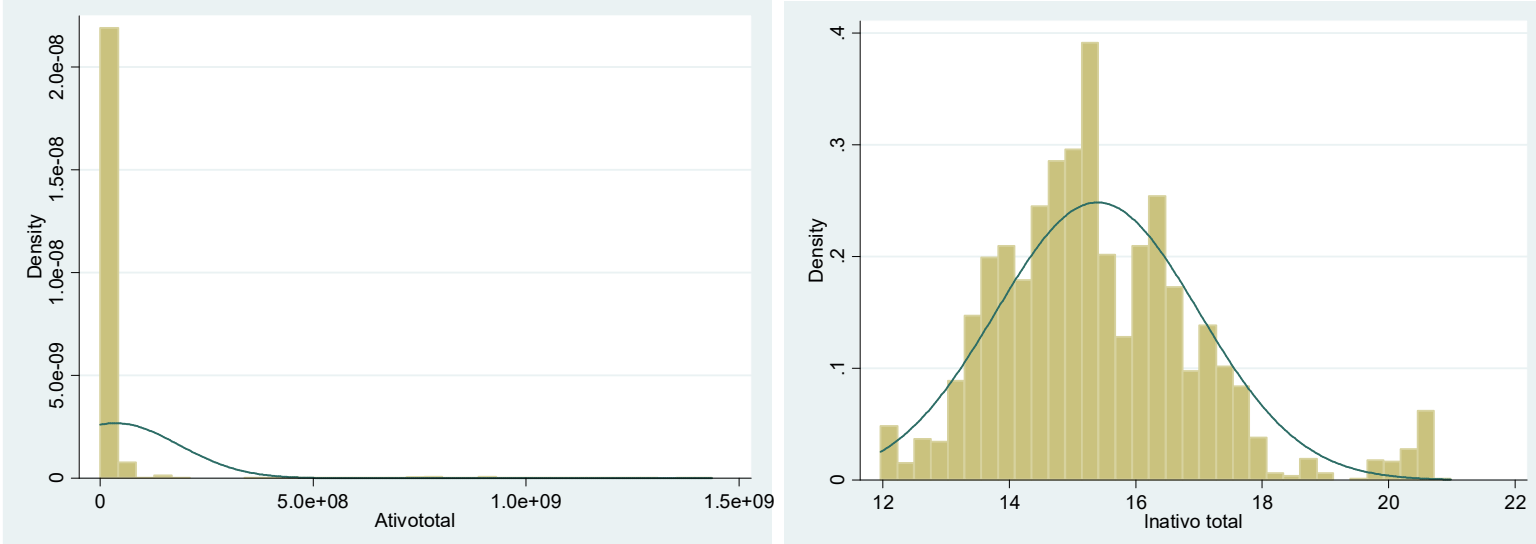

Fonte: Autor

Feitos os devidos ajustes, para testar a hipótese H1, que pretendeu aferir se existe relação positiva e significante entre a cobertura que a mídia faz de uma empresa e seu valor de mercado, foram construídos os dois modelos de regressão multivariada evidenciados abaixo. Na Equação 4, a variável dependente é a medida preço/valor patrimonial, em amostra de 152 empresas que inclui bancos e instituições financeiras. Na Equação 5, o teste foi feito com variável " $Q$ de Tobin", sem bancos e seguradoras, num total de 139 companhias.

$$
\begin{aligned}
\text { PVPA }_{i, t}=\alpha+ & \beta_{1} \text { Publicações }_{i, t}+\beta_{2} \text { Retorno }_{i, t}+\beta_{3} \text { Crescimento }_{i, t}+\beta_{4} \text { Endividamento } \\
& +\beta_{5} \text { Tamanho }_{i, t}+\varepsilon_{i, t}
\end{aligned}
$$


$Q$ de Tobin $_{i, t}=\alpha+\beta_{1}$ Publicações $_{i, t}+\beta_{2}$ Retorno $_{i, t}+\beta_{3}$ Crescimento $_{i, t}+$ $\beta_{4}$ Endividamento $_{i, t}+\beta_{5}$ Tamanho $_{i, t}+\varepsilon_{i, t}$

(Equação 5)

Para testar a hipótese $\mathrm{H} 2$, que pretende aferir se existe relação positiva e significante entre a cobertura que a mídia faz de uma empresa e a liquidez de suas ações, foi construído o modelo de regressão multivariada expresso na Equação 6 .

$$
\begin{aligned}
& \text { Ln } \text { (Liquidez }_{i, t}=\alpha+\beta_{1} \text { Publicações }_{i, t}+\beta_{2} \text { Retorno }_{i, t}+ \\
& \beta_{3} \text { Crescimento }_{i, t}+\beta_{4} \text { Endividamento }_{i, t}+\beta_{5} \text { Tamanho }_{i, t}+\beta_{6} \text { FatoRelevant }_{i, t}+\varepsilon_{i, t}
\end{aligned}
$$

(Equação 6)

Nas equações acima, temos que:

P/VPA - Variável dependente da Equação 4, é o logaritmo da razão entre valor de mercado e valor patrimonial da empresa

$\boldsymbol{Q}$ de Tobin - Variável dependente da Equação 5, é o logaritmo de $Q$ de Tobin, tal como cálculo explicitado no item 3.2;

Liquidez - Variável dependente da Equação 6, é o logaritmo de Liquidez em bolsa, tal como cálculo explicitado no item 3.2;

Publicações - total de matérias em que cada empresa é citada por trimestre no Valor;

Retorno - rentabilidade sobre o patrimônio líquido médio;

Crescimento - variação da receita líquida em 12 meses;

Endividamento - razão entre o exigível total e o ativo total;

Tamanho - logaritmo do ativo total em milhares de reais;

Fato Relevante - é o número de fatos relevantes divulgados por empresa por trimestre.

Ressalta-se que, na segunda etapa, por ter sido observada a alta correlação entre a variável de interesse "Publicações" e a variável "Tamanho", o que pode ser considerado um indício de multicolinearidade, a amostra foi segregada por porte em quatro quartis, chamadas de Grandes, Médias Altas, Médias Baixas e Pequenas.

\subsection{Conexão do constructo teórico com modelo empírico}

Para auxiliar a compreensão do leitor para a conexão que se fez entre o constructo teórico e conceitual e o modelo empírico que foi estruturado, procurou-se inspiração no modelo desenvolvido por Libby, Bloomfield e Nelson (2002), chamado de Libby Box. 
O mapeamento da parte empírica deste estudo, incluindo as definições conceituais e operacionais das variáveis analisadas, encontra-se representado na Figura 9, conforme modelo de Libby, Bloomfield e Nelson (2002).

Figura 9. Libby Box

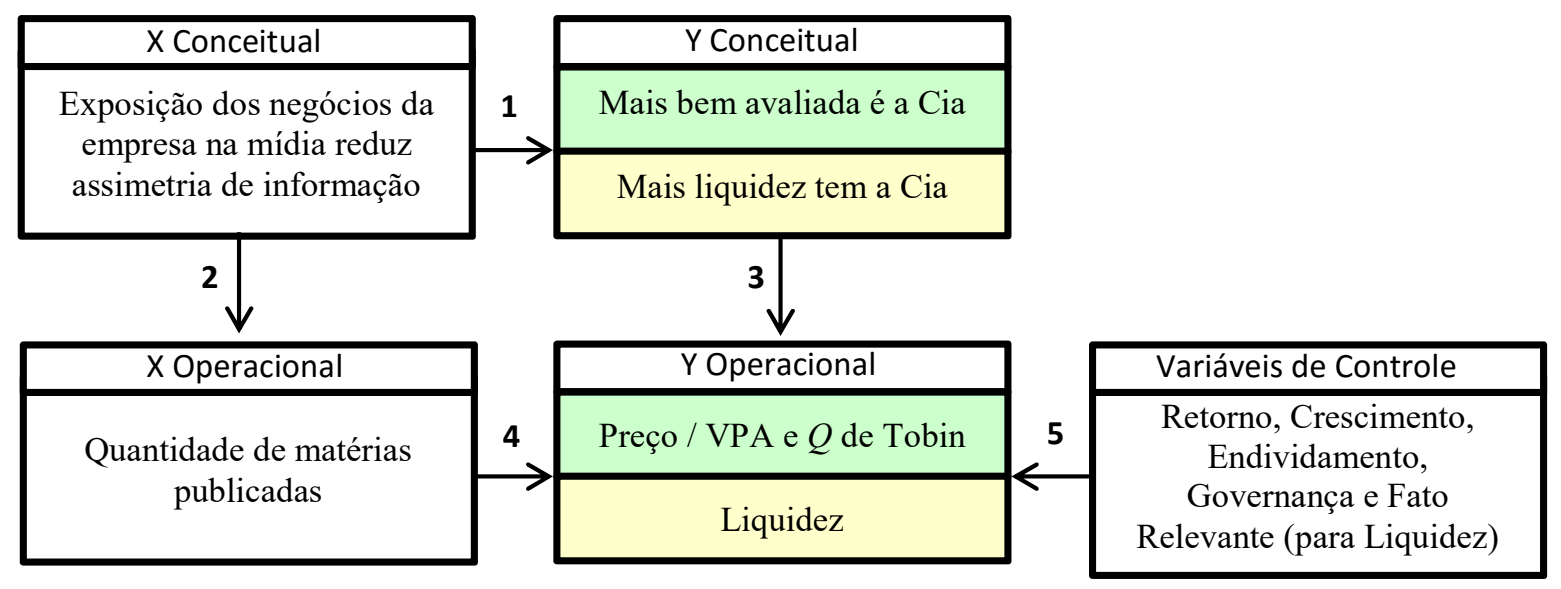

Fonte: Libby, Bloomfield e Nelson (2002), com adaptação do autor

O link 1, na horizontal, que liga os dois primeiros retângulos, representa a relação da teoria subjacente de que a redução da assimetria informacional e efeito negligência e o viés de familiaridade, inclusive com exposição na mídia, podem estar positivamente correlacionadas com a liquidez das ações e com o valor de mercado da empresa. Considerando-se que nenhuma teoria pode ser testada diretamente, tal procedimento é realizado por meio da avaliação da relação entre as definições operacionais de conceitos chave da teoria (link 4). A exposição na mídia é, portanto, capturada neste trabalho, de forma aproximada, obviamente, por meio da coleta de citações das empresas no jornal Valor Econômico. Já a boa avaliação da empresa e o volume de negócios com suas ações são medidos, no trabalho, pelos múltiplos P/VPA e $Q$ de Tobin e pelo índice de liquidez em bolsa. Para que este teste seja válido, as ligações entre os conceitos e as definições operacionais (links 2 e 3) devem ser válidas, ou seja, os links 2 e 3 do libby boxes conectam as definições conceituais e operacionais das variáveis X e Y (Pippin, 2006). 


\section{ANÁLISE DOS DADOS}

\subsection{População total}

Os modelos de regressão para Dados em Painel têm como objetivo principal estudar o comportamento de uma variável dependente em relação às variáveis explicativas de interesse e de controle, cujas alterações podem ocorrer tanto entre indivíduos no mesmo momento no tempo (corte transversal) como ao longo dos períodos estudados (Fávero, 2015).

Essa característica implica que a variância a ser capturada é decomposta em duas partes. Quando os valores de determinadas variáveis se alteram ao longo do tempo para um mesmo indivíduo, estamos diante do que é chamado de variância within (que nas tabelas deste trabalho aparece indicada pelo termo "Dentro"), descreve Fávero (2015). Já as diferenças de valores entre indivíduos no mesmo instante temporal representam a variação between (nas tabelas aparece com a palavra "Entre"). Da combinação dessas duas variâncias, explica o autor, se extrai a variância total, chamada em inglês de overall, que indica a discrepância que existe em um determinado dado de um indivíduo num instante de tempo em relação a todos os demais dados daquela mesma variável para a base completa.

Esse preâmbulo se faz necessário porque, nas regressões para Dados em Painel, o $\mathrm{R}^{2}$, que é a medida que indica o percentual de variância da variável dependente que é explicado pelo modelo proposto, é apresentado dessa forma decomposta, ou seja, com o $\mathrm{R}^{2}$ Dentro, o $\mathrm{R}^{2}$ Entre e o $\mathrm{R}^{2}$ Total.

As características da amostra avaliada neste trabalho indicam para o uso da modalidade de Dados em Painel que pressupõe a existência de efeitos fixos determinando as características das variáveis explicativas. Ao mesmo tempo, com o auxílio do software Stata, foram realizados os testes de Chow, LM de Breusch Pagan e Schalfer e Stillman (equivalente ao teste robusto de Hausman), para os três modelos: "P/VPA", “ $Q$ de Tobin" e "Liquidez", e os resultados de todos os testes confirmaram a adequação dessa opção. É por essa razão que os resultados serão apresentados com mais detalhes com o uso desse modelo. De qualquer forma, no próximo item serão apresentados os resultados obtidos com os outros modelos, que também indicaram resultados com significância estatística e na mesma direção. 
O primeiro teste realizado, cujo resultado aparece na Tabela 7, procurou investigar a relação entre a variável de interesse "Publicações" com a variável dependente P/VPA, que é uma medida de avaliação de empresa por múltiplo de seu valor patrimonial.

Apenas para conhecer melhor o comportamento das variáveis, usou-se o software Stata para construir o gráfico abaixo, na Figura 10, que mostra a correlação simples entre as duas variáveis principais desse primeiro teste. A linha em vermelho indica que existe uma correlação positiva, ainda que pequena, entre as duas medidas. Ou seja, sem que isso signifique uma relação de causa e efeito, o gráfico mostra que, quanto mais citações da empresa na mídia, maior é seu valor de mercado medido pela métrica "P/VPA".

\section{Figura 10. Gráfico de correlação entre P/VPA e Publicações}

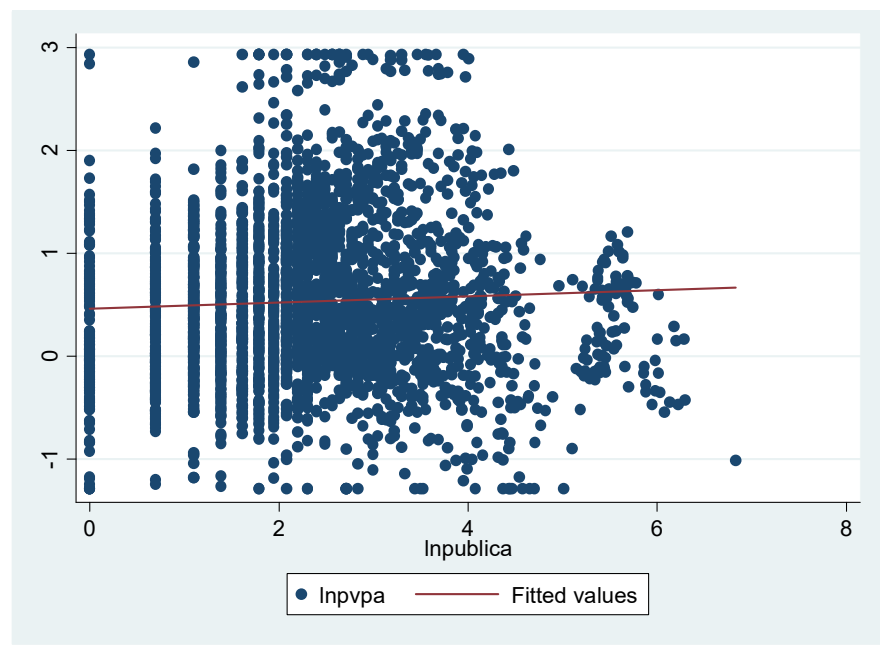

Fonte: Autor

Mais importante que a simples correlação matemática, no entanto, é a realização de teste estatístico para avaliar a significância dessa relação, na presença de variáveis de controle. Para tanto, foi usada uma regressão com Dados em Painel com efeitos fixos e erros-padrão robustos.

Ainda que o objetivo deste estudo seja de diagnóstico, e não de previsão, optou-se pelo uso de modelos robustos de regressão, uma vez que eles apresentaram erros-padrão maiores, o que significa um conservadorismo maior para a validação da significância dos parâmetros (lembrando que nas regressões simples ou robustas os coeficientes e o $\mathrm{R}^{2}$ são idênticos). Além disso, a regressão que considera a existência de erros-padrão robustos com agrupamento por 
indivíduo é defendida por autores como Fávero (2015) e Gujarati (2006), quando há heterocedasticidade nos erros, como indicam as figuras 10,11 e 12.

Conforme consta da Tabela 7, a estatística F e seu p-valor indicaram que, com um nível de confiança de 99\%, é possível rejeitar a hipótese nula de que todos os parâmetros testados a saber, "Publicações", "Retorno", "Crescimento", "Endividamento" e "Tamanho" - tenham beta estatisticamente iguais a zero para explicar a variável dependente "P/VPA". Ou seja, esse teste indica que pelo menos um parâmetro é estatisticamente diferente de zero. O total de observações empresa-trimestre ficou em 2.596, abaixo do máximo de 3.040, por conta da existência de missing values.

Já as estatísticas $t$ mostram que, na verdade, todos os cinco parâmetros testados neste modelo, além da constante $\alpha$, tiveram p-valor abaixo de $1 \%$ na presença das demais variáveis, incluindo a variável de interesse "Publicações". Isso indica que a cobertura da mídia tem poder para explicar o comportamento do valor de mercado das empresas analisadas durante esse período e que essa relação é positiva.

O $\mathrm{R}^{2}$ Total mostra que o modelo estruturado foi capaz de explicar 30,16\% da variância da variável dependente "P/VPA". A decomposição dessa variância mostra ainda que o $\mathrm{R}^{2}$ Entre, que trata das discrepâncias entre indivíduos, ficou em $31,85 \%$, enquanto o $\mathrm{R}^{2}$ Dentro ficou em $18,38 \%$.

Também conforme esperado pela teoria, as variáveis "Retorno", "Crescimento", "Endividamento" se mostraram estatisticamente significativas, ao nível de 1\%, para explicar o valor de mercado das empresas, e todas com sinal positivo. A variável "Tamanho" apresentou sinal negativo na presença das demais variáveis do modelo. 
Tabela 7. Regressão robusta com dados em painel com efeitos fixos, para variável dependente P/VPA

\begin{tabular}{lcccc}
\hline P/VPA & Coeficiente & Erro padrão robusto & Estatística $t$ & p-valor \\
\hline Publicações & 0,0813 & 0,0178 & 4,56 & $0,000^{* * *}$ \\
Retorno & 0,0091 & 0,0023 & 3,92 & $0,000^{* * *}$ \\
Crescimento & 0,0020 & 0,0005 & 3,73 & $0,000^{* * *}$ \\
Endividamento & 0,0129 & 0,0035 & 3,72 & $0,000^{* * *}$ \\
Tamanho & $-0,2207$ & 0,0628 & $-3,52$ & $0,001^{* * *}$ \\
Constante & 2,8583 & 0,8855 & 3,23 & $0,002^{* * *}$ \\
\hline
\end{tabular}

$\mathrm{R}^{2}$

$\begin{array}{lc}\text { Dentro } & 0,1838 \\ \text { Entre } & 0,3185 \\ \text { Total } & 0,3016 \\ \text { Estatística F } & 15,80^{* * *} \\ \text { Observações } & 2.596\end{array}$

Notas: P/VPA é o logaritmo da relação entre o valor de mercado da empresa e o seu valor patrimonial; Publicações é o logaritmo natural do número de matérias em que cada empresa é citada por trimestre no jornal Valor; Retorno é a rentabilidade sobre o patrimônio líquido de cada empresa; Crescimento é a variação da receita em 12 meses; Endividamento é a razão entre o exigível total e o ativo total da empresa; e Tamanho é o logaritmo natural do ativo total da empresa em milhares de reais.

*variável significativa a $10 \%$; ** variável significativa a $5 \%$; e *** variável significativa a $1 \%$

Fonte: Autor

Ainda procurando responder a Hipótese 1 do trabalho, rodou-se mais um modelo que procurou testar a relação entre a cobertura da mídia e o valor de mercado das empresas. No segundo caso, a variável dependente usada foi o " $Q$ de Tobin", cujo cálculo simplificado utilizado está descrito nas Equações 1 e 2 citadas no Capítulo 3. Por conta das medidas contábeis usadas para se chegar ao " $Q$ de Tobin", foram excluídas da amostra os bancos e seguradoras, restando no modelo 139 empresas. Por causa da existência de missing values, o total de observações empresa-trimestre ficou em 2.424, abaixo do máximo possível de 2.780, dada a existência de 20 trimestres na série temporal.

Da mesma forma que se fez no modelo anterior, apresenta-se primeiro, na Figura 11, o gráfico de correlação entre as principais variáveis que se pretende estudar. Assim como no primeiro caso, é possível notar que existe uma correlação positiva entre as duas medidas, indicando que as empresas mais acompanhadas pela imprensa têm maior valor de mercado relativo. 
Figura 11. Gráfico de correlação entre $Q$ de Tobin e Publicações

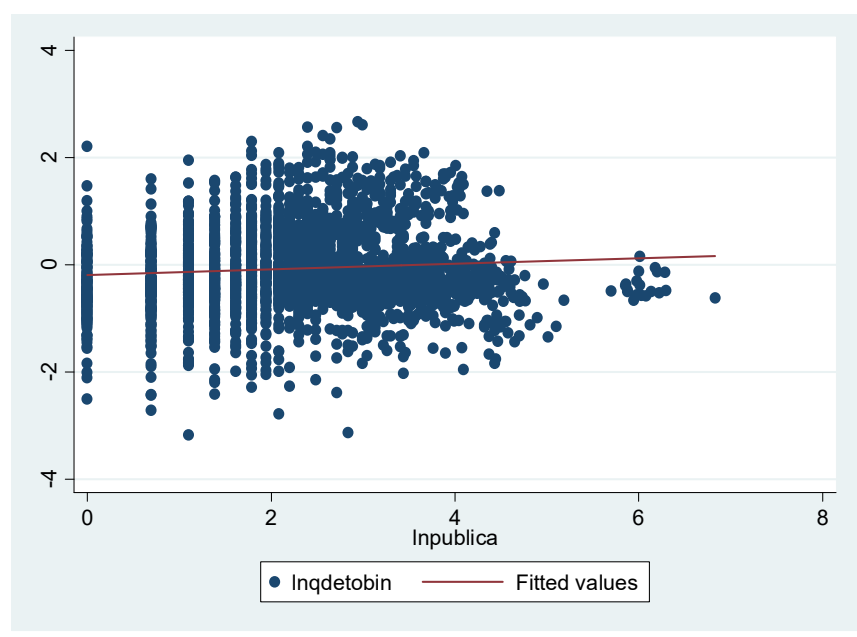

Fonte: Autor

Foi feito então, em seguida, um teste estatístico para avaliar a significância dessa relação, na presença de variáveis de controle. Para tanto, foi usada uma regressão com Dados em Painel com efeitos fixos e erros-padrão robustos, cujos resultados estão na Tabela 8.

Em linha com o resultado anterior, a estatística $\mathrm{F}$ e seu p-valor indicaram que, com um nível de confiança de $99 \%$, é possível rejeitar a hipótese nula de que todos os parâmetros testados - a saber, "Publicações", "Retorno", "Crescimento", "Endividamento" e "Tamanho" - tenham beta estatisticamente iguais a zero para explicar a variável dependente " $Q$ de Tobin". Ou seja, esse teste indica que pelo menos um parâmetro é estatisticamente diferente de zero.

As estatísticas $t$ mostram que, dos cinco parâmetros testados neste modelo, apenas as variáveis "Publicações", "Retorno" e "Crescimento" tiveram p-valor abaixo de $1 \%$ na presença das demais variáveis. A variável "Tamanho" só passa com nível de significância menos rigoroso, de $10 \%$. 
Tabela 8. Regressão robusta com dados em painel com efeitos fixos, para variável dependente $Q$ de Tobin - com todas as variáveis

\begin{tabular}{|c|c|c|c|c|}
\hline$Q$ de Tobin & Coeficiente & Erro-padrão robusto & Estatística $t$ & p-valor \\
\hline Publicações & 0,0698 & 0,0162 & 4,30 & $0,000 * * *$ \\
\hline Retorno & 0,0068 & 0,0015 & 4,62 & $0,000 * * *$ \\
\hline Crescimento & 0,0022 & 0,0005 & 4,47 & $0,000 * * *$ \\
\hline Endividamento & 0,0004 & 0,0023 & 0,17 & 0,865 \\
\hline Tamanho & $-0,0925$ & 0,0507 & $-1,82$ & $0,070^{*}$ \\
\hline Constante & 1,0004 & 0,7436 & 1,35 & 0,181 \\
\hline \multicolumn{5}{|l|}{$\mathrm{R}^{2}$} \\
\hline Dentro & 0,1438 & & & \\
\hline Entre & 0,4649 & & & \\
\hline Total & 0,3833 & & & \\
\hline Estatística F & $16,43 * * *$ & & & \\
\hline Observações & 2.424 & & & \\
\hline \multicolumn{5}{|c|}{ 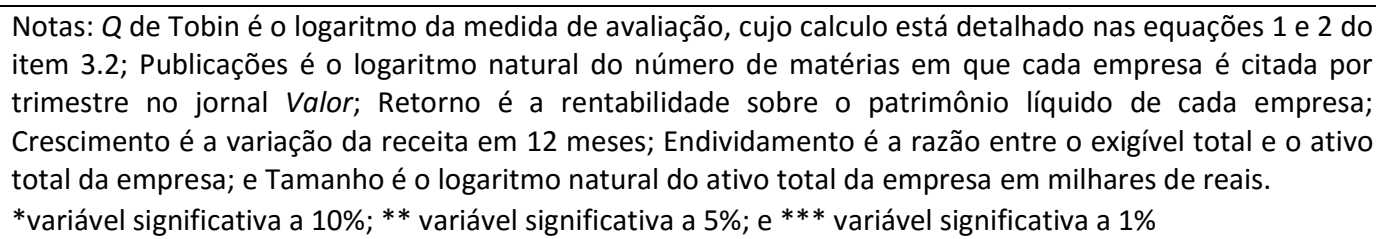 } \\
\hline
\end{tabular}

Optou-se então por rodar novamente o modelo, tirando da equação as variáveis que não mostraram significância estatística.

Nesse segundo cenário, a estatística $\mathrm{F}$ aumentou de 16,43 para 20,41, enquanto o $\mathrm{R}^{2}$ Total subiu de 38,33\% no modelo inicial para 38,99\% no ajustado. Esse resultado indica que as variáveis explicativas incluídas na equação explicam pouco menos de $40 \%$ da variância do " $Q$ de Tobin" das empresas. A decomposição do $\mathrm{R}^{2}$ indica que o modelo tem poder maior para explicar a variância entre os indivíduos, com o $\mathrm{R}^{2}$ Entre de $47,63 \%$, do que a variância intertemporal dentro da mesma empresa, trazida pelo $\mathrm{R}^{2}$ Dentro, que ficou em 14,38\%.

Vale notar que neste segundo caso a variável de interesse "Publicações" seguiu apresentando sinal positivo, em linha com o esperado pela teoria, e poder explicativo estatisticamente significante ao nível 1\%. Os sinais positivos para "Retorno" e "Crescimento" foram consistentes com o teste que teve como base a variável dependente "P/VPA", da mesma forma que o sinal negativo para a variável "Tamanho" se repetiu, neste segundo modelo com nível de significância menor. 
Tabela 9. Regressão robusta com dados em painel com efeitos fixos, para variável dependente $Q$ de Tobin - apenas com variáveis significativas

\begin{tabular}{|c|c|c|c|c|}
\hline$Q$ de Tobin & Coeficiente & Erro-padrão robusto & Estatística $t$ & p-valor \\
\hline Publicações & 0,0697 & 0,0163 & 4,29 & $0,000 * * *$ \\
\hline Retorno & 0,0068 & 0,0014 & 4,73 & $0,000 * * *$ \\
\hline Crescimento & 0,0022 & 0,0005 & 4,46 & $0,000 * * *$ \\
\hline Tamanho & $-0,0888$ & 0,0461 & $-1,93$ & $0,056^{*}$ \\
\hline Constante & 0,9657 & 0,7172 & 1,35 & 0,180 \\
\hline \multicolumn{5}{|l|}{$\mathrm{R}^{2}$} \\
\hline Dentro & 0,1438 & & & \\
\hline Entre & 0,4763 & & & \\
\hline Total & 0,3899 & & & \\
\hline Estatística F & $20,41 * * *$ & & & \\
\hline Observações & 2.424 & & & \\
\hline \multicolumn{5}{|c|}{ 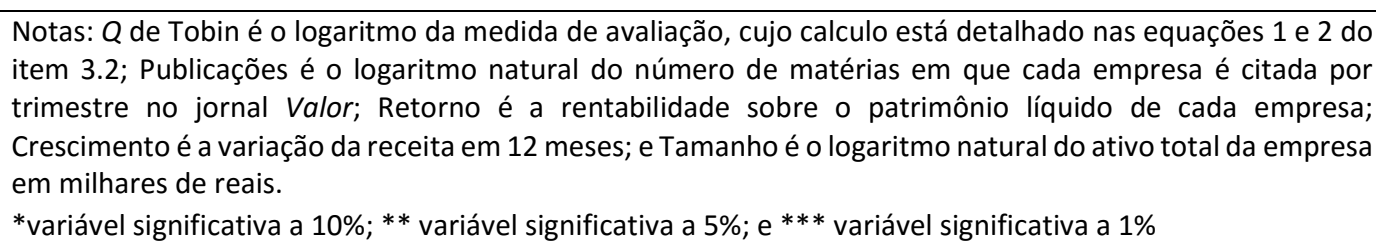 } \\
\hline
\end{tabular}

O terceiro teste a ser realizado procurou responder a Hipótese 2 apresentada no trabalho, que trata da relação entre a cobertura da mídia e a liquidez das ações das empresas.

De forma semelhante ao realizado nos dois casos anteriores, apenas para conhecer melhor o comportamento das variáveis, usou-se o software Stata para construir o gráfico que aparece na Figura 12, que mostra a correlação simples entre as variáveis "Publicações" e "Liquidez". A linha em vermelho indica que existe uma correlação positiva e bastante elevada entre as duas medidas, bem mais alta do que aquela observada entre "Publicações" e "P/VPA", que aparece na Figura 10, e entre "Publicações" e " $Q$ de Tobin", na Figura 11. 


\section{Figura 12. Gráfico de correlação entre Liquidez e Publicações}

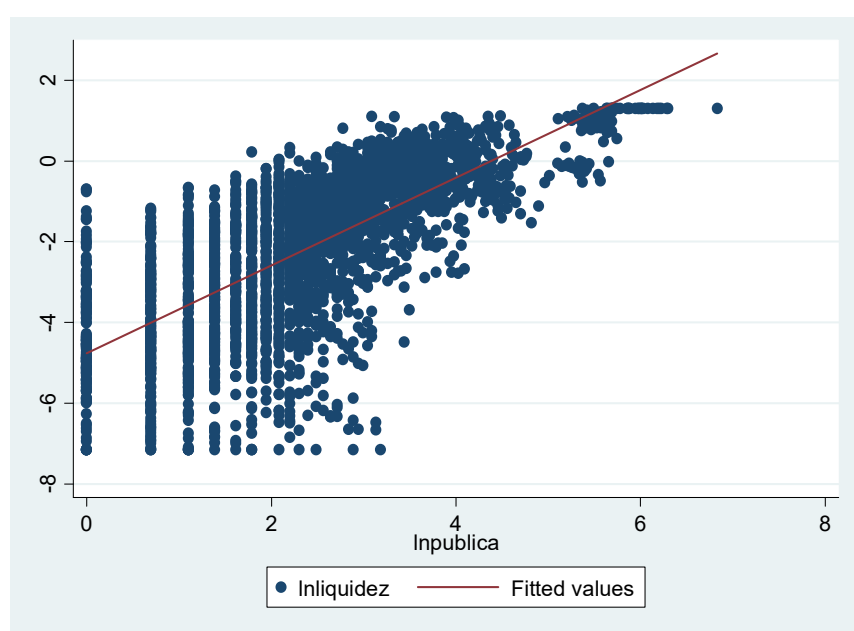

Fonte: Autor

A existência de uma correlação altamente positiva como mostra a Figura 12 sugere a existência de relação estatisticamente significante entre as duas variáveis. Para confirmar essa suposição, foi feita uma regressão com Dados em Painel com efeitos fixos e erros-padrão robustos, cujos resultados estão na Tabela 10. Cabe notar que, conforme descrito na Equação 6 que aparece no Capítulo 3, neste terceiro teste foi incluída a variável de controle "Fato Relevante", com o objetivo de tentar capturar uma alteração do nível de liquidez da empresa que pudesse se justificar por divulgações feitas diretamente pela companhia, a despeito do nível de cobertura da mídia.

Assim como nos demais modelos, a estatística $\mathrm{F}$ e seu p-valor indicaram que, com um nível de confiança de 99\%, é possível rejeitar a hipótese nula de que todos os parâmetros testados - a saber, "Publicações", "Retorno", "Crescimento", "Endividamento", "Tamanho" e "Fato Relevante" - tenham beta estatisticamente iguais a zero para explicar a variável dependente "Liquidez". Ou seja, esse teste indica que pelo menos um parâmetro é estatisticamente diferente de zero.

As estatísticas $t$ mostram, contudo, que, dos seis parâmetros testados neste modelo, apenas as variáveis "Publicações", "Retorno" e "Tamanho" tiveram p-valor abaixo de 1\% na presença das demais variáveis. As variáveis "Crescimento", "Endividamento" e "Fato Relevante" não se mostraram estatisticamente significantes para explicar variável dependente "Liquidez". 
que consideraram as variáveis dependentes "P/VPA", " $Q$ de Tobin" e "Liquidez". Os resultados de todos os testes apontaram para a utilização dos efeitos fixos.

Mesmo que os resultados dos testes não tivessem apontado para isso, cabe notar que o modelo de efeitos fixos é recomendado para este caso, já que características intrínsecas de cada companhia determinam diferentes "patamares" para suas variáveis. Como diz Fávero (2015), "se existirem razões para acreditar que os efeitos individuais estejam correlacionados com as variáveis explicativas, a estimação por efeitos aleatórios oferecerá parâmetros inconsistentes e o modelo por efeitos fixos será mais adequado". O modelo de efeitos fixos considera a existência de efeitos individuais que representam a heterogeneidade entre os indivíduos que são invariantes no tempo, que se refletem em interceptos diferentes, ou seja, na constante $\alpha$ das equações, e não nas inclinações (ou coeficientes $\beta$ )

Ainda assim, para reforçar a robustez dos resultados encontrados e para evitar qualquer crítica sobre eventual viés na escolha do modelo que mais favorecesse a tese apresentada pelo pesquisador, apresenta-se na Tabela 12 um quadro comparativo com os resultados encontrados usando-se diferentes modelos de regressão. Cabe notar que, como nos modelos que não usam efeito fixo foi possível o uso de variáveis ligadas a governança corporativa das empresas, que estão no formato de dummy, elas foram incluídas no respectivo teste, sempre que mostraram nível de significância estatística até o limite de $10 \%$ — critério que também foi seguido com as variáveis quantitativas originais.

Os dois primeiros modelos, que na tabela são identificados como POLS e Cluster2, apresentam os mesmo coeficientes e o mesmo $\mathrm{R}^{2}$. Nota-se que em ambos os casos não existe decomposição da variância do $\mathrm{R}^{2}$, já que são modelos de regressão comum.

O modelo POLS, cuja sigla vem do inglês Pooled Ordinary Least Squares, trata a base do painel como uma grande regressão em corte transversal, mas neste caso houve o controle da autocorrelação entre os termos de erro para um dado indivíduo, por meio da utilização de errospadrão robustos com agrupamento no nível do indivíduo.

Já o modelo chamado de Cluster2, sugerido por Petersen (2009) e usado por Fávero, Almeida e Takamatsu (2014), tem o mesmo princípio que o POLS, com a diferença de que faz esse controle com uso de erros-padrão robustos com agrupamento no nível do indivíduo e também no período. A diferença entre os dois modelos, como se nota na Tabela 12, está apenas 
nos termos de erro, sendo que no teste realizado ela é muito pequena e não alterara a significância das variáveis.

A estimação between, chamada na tabela de BE, considera somente a variação entre os indivíduos e tem como desvantagem, segundo Fávero (2015), a necessidade de que os termos de erro não sejam correlacionados com uma ou mais variáveis explicativas. Segundo Hsiao (2003, citado por Fávero, 2015) e Cameron e Trivedi (2009, citado por Fávero, 2015), esta estimação é raramente utilizada pelo fato de os estimadores obtidos pelos modelos POLS ou com efeitos aleatórios acabarem sendo mais eficientes.

Por fim, apresenta-se também, sob a sigla EA Rob na Tabela 12, o teste feito com efeitos aleatórios com erros-padrão robustos com agrupamento por indivíduo. Esse tipo de modelo tem por trás a premissa de que a variação entre indivíduos é aleatória e não correlacionada com as variáveis explicativas.

Como se nota nos resultados, em todos os cinco modelos testados, as estatísticas F (ou o Chi2 de Wald no caso de efeitos aleatórios) e seus respectivos p-valores indicaram que, com um nível confiança de 99\%, é possível rejeitar a hipótese nula de que todos os parâmetros testados - a saber, "Publicações", "Retorno", "Crescimento", "Endividamento", "Tamanho", "Nível Tradicional", "Nível 2", "Novo Mercado" e "SEC"- tenham beta estatisticamente iguais a zero para explicar as variáveis dependentes: "P/VPA", “ $Q$ de Tobin” e "Liquidez".

Já as estatísticas $t$ (ou $z$ no caso de efeitos aleatórios), que se referem a cada uma das variáveis explicativas no modelo, indicam que a variável de interesse "Publicações" se mostrou estatisticamente significante, com nível de confiança de $99 \%$, em todos os 15 modelos testados, ou seja, em cada um dos cinco tipos de regressão usada, para cada uma das três variáveis dependentes. Os sinais também foram sempre positivos, indicando que, na presença das demais variáveis, as empresas mais acompanhadas pela mídia têm valor de mercado e liquidez maiores do que as menos seguidas pelos jornalistas.

No caso da variável dependente "P/VPA", os modelos de regressão POLS e Cluster2 apresentaram o maior poder explicativo, com $\mathrm{R}^{2}$ de $52,75 \%$. Nos dois casos, todas as variáveis originalmente quantitativas foram estatisticamente significantes ao nível de confiança de $95 \%$.

Nos testes com efeitos fixos e aleatórios, todas as variáveis testadas se mostraram estatisticamente relevantes para explicar o "P/VPA" das empresas no período analisado, ao nível de significância de $1 \%$. Vale notar que, enquanto os coeficientes da variável 
"Publicações" apurados nos modelos POLS e Cluster 2 ficaram 0,226, nos modelos que consideram efeitos fixos e aleatórios eles foram mais baixos, de 0,081 e 0,093 respectivamente. A variável "Tamanho" foi a única que, na presença das demais variáveis, apresentou sinal negativo de forma consistente nos cinco testes para explicar a variância do valor de mercado das empresas quando medidos em comparação com seu valor patrimonial.

Tabela 12. Regressão robusta com dados em painel com efeitos fixos, para variável dependente P/VPA - comparação entre modelos

\begin{tabular}{|c|c|c|c|c|c|}
\hline P/VPA & POLS & Cluster2 & $\mathrm{BE}$ & EF Rob & EA Rob \\
\hline Publicações & $0,226^{* * *}$ & $0,226 * * *$ & $0,316^{* * *}$ & $0,081 * * *$ & $0,093 * * *$ \\
\hline Erro-padrão & 0,037 & 0,038 & 0,066 & 0,018 & 0,018 \\
\hline Retorno & $0,023 * * *$ & $0,023 * * *$ & $0,025 * * *$ & $0,009 * * *$ & $0,011 * * *$ \\
\hline Erro-padrão & 0,002 & 0,002 & 0,002 & 0,002 & 0,002 \\
\hline Crescimento & $0,002 * *$ & $0,002 * *$ & $0,006^{*}$ & $0,002 * * *$ & $0,002 * * *$ \\
\hline Erro-padrão & 0,001 & 0,001 & 0,003 & 0,001 & 0,001 \\
\hline Endividamento & $0,005^{* *}$ & $0,005^{* *}$ & $0,004 *$ & $0,013^{* * *}$ & $0,011^{* * *}$ \\
\hline Erro-padrão & 0,002 & 0,002 & 0,002 & 0,003 & 0,003 \\
\hline Tamanho & $-0,208 * * *$ & $-0,208 * * *$ & $-0,259 * * *$ & $-0,221 * * *$ & $-0,184 * * *$ \\
\hline Erro-padrão & 0,040 & 0,039 & 0,051 & 0,063 & 0,039 \\
\hline N. Tradicional & $0,436 * *$ & $0,436 * *$ & $0,349 *$ & & $0,694 * * *$ \\
\hline Erro-padrão & 0,184 & 0,179 & 0,183 & & 0,260 \\
\hline Novo Mercado & $0,296 * * *$ & $0,296 * * *$ & $0,263 * * *$ & & $0,313 * * *$ \\
\hline Erro-padrão & 0,093 & 0,090 & 0,676 & & 0,105 \\
\hline Constante & $2,344 * * *$ & $2,344 * * *$ & $2,915 * * *$ & $2,858 * * *$ & $2,095 * * *$ \\
\hline Erro-padrão & 0,552 & 0,540 & 0,676 & 0,886 & 0,577 \\
\hline \multicolumn{6}{|l|}{$\mathrm{R}^{2}$} \\
\hline Dentro & & & 0,147 & 0,184 & 0,181 \\
\hline Entre & & & 0,648 & 0,319 & 0,447 \\
\hline Total & 0,5275 & 0,5275 & 0,512 & 0,302 & 0,408 \\
\hline Estatística F & $37,24^{* * *}$ & $311,21 * * *$ & $37.53^{* * *}$ & $15,80 * * *$ & \\
\hline Chi2 Wald & & & & & $131,24 * * *$ \\
\hline Observações & 2.596 & 2.596 & 2.596 & 2.596 & 2.596 \\
\hline \multicolumn{6}{|c|}{$\begin{array}{l}\text { Notas: P/VPA é o logaritmo da relação entre o valor de mercado da empresa e o seu valor patrimonial; Publicações } \\
\text { é o logaritmo natural do número de matérias em que cada empresa é citada por trimestre no jornal Valor; Retorno } \\
\text { é a rentabilidade sobre o patrimônio líquido de cada empresa; Crescimento é a variação da receita em } 12 \text { meses; } \\
\text { Endividamento é a razão entre o exigível total e o ativo total da empresa; e Tamanho é o logaritmo natural do ativo } \\
\text { total da empresa em milhares de reais. POLS é a estimação por modelo de regressão mesclado, com erros-padrão } \\
\text { robustos com agrupamento por indivíduo; Cluster2 é a estimação com agrupamento por indivíduo e por período; } \\
\text { BE é a estimação between, ou entre as empresas; EF Rob é o modelo com efeitos fixos com erros-padrão robustos; } \\
\text { e EA Rob é o modelo com efeitos aleatórios com erros-padrão robustos. } \\
\text { "variável significativa a 10\%; ** variável significativa a 5\%; e *** variável significativa a 1\% }\end{array}$} \\
\hline
\end{tabular}

Fonte: Autor 
No caso da variável dependente " $Q$ de Tobin", que aparece na Tabela 13, os modelos POLS e Cluster2 também apresentaram $\mathrm{R}^{2}$ Total maior, de 44,16\%, enquanto nos demais casos ele ficou abaixo dos 40\%. A variável de interesse "Publicações" foi estatisticamente significante em todos os testes, com nível de confiança de $99 \%$.

Tabela 13. Regressão robusta com dados em painel com efeitos fixos, para variável dependente $Q$ de Tobin - comparação entre modelos

\begin{tabular}{|c|c|c|c|c|c|}
\hline$Q$ de Tobin & POLS & Cluster2 & $\mathrm{BE}$ & EF Rob & EA Rob \\
\hline Publicações & $0,208 * * *$ & $0,208 * * *$ & $0,305^{* * *}$ & $0,070 * * *$ & $0,075 * * *$ \\
\hline Erro-padrão & 0,036 & 0,036 & 0,075 & 0,016 & 0,016 \\
\hline Retorno & $0,018 * * *$ & $0,018 * * *$ & $0,019 * * *$ & $0,007 * * *$ & $0,008 * * *$ \\
\hline Erro-padrão & 0,002 & 0,002 & 0,002 & 0,001 & 0,001 \\
\hline Crescimento & $0,003 * * *$ & $0,003 * *$ & $0,012 * * *$ & $0,002 * * *$ & $0,002 * * *$ \\
\hline Erro-padrão & 0,001 & 0,001 & 0,003 & 0,000 & 0,000 \\
\hline Endividamento & $-0,005^{* *}$ & $-0,005^{* *}$ & $-0,006^{* *}$ & & \\
\hline Erro-padrão & 0,002 & 0,002 & 0,003 & & \\
\hline Tamanho & $-0,176 * * *$ & $-0,176 * * *$ & $-0,259 * * *$ & $-0,089 * * *$ & $-0,097 * * *$ \\
\hline Erro-padrão & 0,038 & 0,038 & 0,059 & 0,046 & 0,038 \\
\hline N. Tradicional & $0,502 * * *$ & $0,502 * * *$ & $0,374^{*}$ & & $0,728 * * *$ \\
\hline Erro-padrão & 0,193 & 0,189 & 0,209 & & 0,262 \\
\hline Novo Mercado & $0,210 * *$ & $0,210 * *$ & & & $0,257^{* *}$ \\
\hline Erro-padrão & 0,094 & 0,092 & & & 0,112 \\
\hline Constante & $1,889 * * *$ & $1,889 * * *$ & $2,980 * * *$ & 0,966 & 0,843 \\
\hline Erro-padrão & 0,570 & 0,563 & 0,752 & 0,717 & 0,623 \\
\hline \multicolumn{6}{|l|}{$\mathrm{R}^{2}$} \\
\hline Dentro & & & 0,1352 & 0,1438 & 0,1435 \\
\hline Entre & & & 0,5338 & 0,4763 & 0,4127 \\
\hline Total & 0,4416 & 0,4416 & 0,3801 & 0,3899 & 0,3658 \\
\hline Estatística F & $35,64 * * *$ & $262,92 * * *$ & $25,19 * * *$ & $20,41^{* * *}$ & \\
\hline Chi2 Wald & & & & & $123,31 * * *$ \\
\hline Observações & 2.424 & 2.424 & 2.424 & 2.424 & 2.424 \\
\hline \multicolumn{6}{|c|}{$\begin{array}{l}\text { Notas: } Q \text { de Tobin é o logaritmo desta medida de avaliação, cujo cálculo é detalhado nas equações } 1 \text { e } 2 \text { do item } \\
3.2 \text { deste trabalho; Publicações é o logaritmo natural do número de matérias em que cada empresa é citada por } \\
\text { trimestre no jornal Valor; Retorno é a rentabilidade sobre o patrimônio líquido de cada empresa; Crescimento é a } \\
\text { variação da receita em } 12 \text { meses; Endividamento é a razão entre o exigível total e o ativo total da empresa; e } \\
\text { Tamanho é o logaritmo natural do ativo total da empresa em milhares de reais. POLS é a estimação por modelo de } \\
\text { regressão mesclado, com erros-padrão robustos com agrupamento por indivíduo; Cluster2 é a estimação com } \\
\text { agrupamento por indivíduo e por período; BE é a estimação between, ou entre as empresas; EF Rob é o modelo } \\
\text { com efeitos fixos com erros-padrão robustos; e EA Rob é o modelo com efeitos aleatórios com erros-padrão } \\
\text { robustos. } \\
\text { *variável significativa a 10\%; ** variável significativa a 5\%; e *** variável significativa a } 1 \%\end{array}$} \\
\hline
\end{tabular}

Fonte: Autor 
A principal diferença dos resultados para " $Q$ de Tobin", no entanto, talvez esteja na variável "Endividamento", que apareceu com sinal negativo nos três primeiros modelos e não se mostrou estatisticamente significativa quando considerados efeitos fixos e aleatórios. Um possível motivo que explica a existência de ruído com essa variável é que a medida de endividamento usada foi extraída da razão entre o exigível total da empresa e seu ativo total. Já o cálculo do " $Q$ de Tobin" tem o mesmo denominador - ou seja, o ativo total contábil da empresa - e no numerador possui um componente relevante do exigível total das empresas (que é sua dívida de longo prazo), acrescida do valor de mercado da companhia.

É interessante notar que, tanto no modelo com "P/VPA" como no teste com " $Q$ de Tobin" o modelo tem mais poder para explicar a variância do valor de mercado entre as companhias do que das próprias empresas ao longo do tempo. Isso pode ser observado pelas métricas de $\mathrm{R}^{2}$ Entre sempre maiores do que as medidas de $\mathrm{R}^{2}$ Dentro.

$\mathrm{Na}$ análise dos resultados com a variável dependente "Liquidez", na Tabela 14, com diferentes regressões, se repete o comportamento em que os modelos POLS e Cluster2 possuem $\mathrm{R}^{2}$ Total maior, em $61,88 \%$, enquanto no teste com efeitos fixos ela ficou em $47,03 \%$ e com efeitos aleatórios, em 54,5\%. A variável "Crescimento" não se mostrou estatisticamente relevante para permanecer nos modelos com efeitos fixos e aleatórios e só entra no POLS e Cluster2 com nível de tolerância maior, com nível de significância em 10\%. Da mesma forma que no teste com efeitos fixos, a variável "Tamanho" aparece com sinal positivo quando relacionada ao volume de negócios com ações das empresas, mesmo na presença de outras variáveis. Já o nível de "Endividamento" tem sinal negativo em todos os modelos testados, embora sem significância estatística quando considerados os efeitos fixos.

O comportamento das variáveis de controle ligadas a governança, que inicialmente são qualitativas, mas foram transformadas em dummies, se mostrou parecido em todos os casos analisados. Em nenhum dos modelos testados as variáveis "Nível 2" e "SEC" se mostraram estatisticamente significantes.

A listagem no "Novo Mercado", por sua vez, se mostrou relevante para explicar a variância de "P/VPA", de " $Q$ de Tobin" (com exceção da estimação between) e "Liquidez", sempre com nível de confiança de pelo menos $95 \%$ e sinal positivo.

Já a variável Nível Tradicional, das empresas que não integram nenhum nível diferenciado de governança da BM\&FBovespa, mostrou associação estatisticamente 
significativa com valor de mercado, tanto com a variável dependente "P/VPA" como com " $Q$ de Tobin". Mas o mesmo não se repetiu, contudo, com a variável "Liquidez".

Tabela 14. Regressão robusta com dados em painel com efeitos fixos, para variável dependente Liquidez - comparação entre modelos

\begin{tabular}{|c|c|c|c|c|c|}
\hline Liquidez & POLS & Cluster2 & $\mathrm{BE}$ & EF Rob & EA Rob \\
\hline Publicações & $0,666^{* * *}$ & $0,666^{* * *}$ & $0,942 * * *$ & $0,199 * * *$ & $0,213^{* * *}$ \\
\hline Erro-padrão & 0,955 & 0,930 & 0,145 & 0,0345 & 0,036 \\
\hline Retorno & $0,012 * *$ & $0,012 * *$ & $0,013 * * *$ & $0,0082 * * *$ & $0,008 * * *$ \\
\hline Erro-padrão & 0,005 & 0,005 & 0,004 & 0,0026 & 0,003 \\
\hline Crescimento & $0,003 *$ & $0,003 *$ & $0,021 * *$ & & \\
\hline Erro-padrão & 0,002 & 0,002 & 0,007 & & \\
\hline Endividamento & $-0,022 * * *$ & $-0,022 * * *$ & $-0,024 * * *$ & & $-0,009 *$ \\
\hline Erro-padrão & 0,005 & 0,004 & 0,005 & & 0,005 \\
\hline Tamanho & $0,601 * * *$ & $0,601 * * *$ & $0,419 * * *$ & $0,958 * * *$ & $0,958 * * *$ \\
\hline Erro-padrão & 0,096 & 0,094 & 0,113 & 0,1613 & 0,117 \\
\hline Novo Mercado & $0,840 * * *$ & $0,840 * * *$ & $0,697^{* * *}$ & & $1,183 * * *$ \\
\hline Erro-padrão & 0,204 & 0,199 & 0,214 & & 0,272 \\
\hline Constante & $-12,612 * * *$ & $-12,612 * * *$ & $-10,587 * * *$ & $-17,585^{* * *}$ & $-17,979 * * *$ \\
\hline Erro-padrão & 1,358 & 1,326 & 1,474 & 2,5051 & 1,825 \\
\hline \multicolumn{6}{|l|}{$\mathrm{R}^{2}$} \\
\hline Dentro & & & 0,0298 & 0,1736 & 0,174 \\
\hline Entre & & & 0,7141 & 0,4916 & 0,590 \\
\hline Total & 0,6188 & 0,6188 & 0,5648 & 0,4703 & 0,545 \\
\hline Estatística F & $52,90 * * *$ & $688,04 * * *$ & $60,37 * * *$ & $24,61 * * *$ & \\
\hline Chi2 Wald & & & & & $158,11 * * *$ \\
\hline Observações & 2.611 & 2.611 & 2.611 & 2.696 & 2.696 \\
\hline \multicolumn{6}{|c|}{$\begin{array}{l}\text { Notas: Liquidez é o logaritmo de Liquidez em bolsa, cujo cálculo é detalhado na equação } 3 \text { do item } 3.2 \text { Publicações } \\
\text { é o logaritmo natural do número de matérias em que cada empresa é citada por trimestre no jornal Valor; Retorno } \\
\text { é a rentabilidade sobre o patrimônio líquido de cada empresa; Crescimento é a variação da receita em } 12 \text { meses; } \\
\text { Endividamento é a razão entre o exigível total e o ativo total da empresa; e Tamanho é o logaritmo natural do ativo } \\
\text { total da empresa em milhares de reais. POLS é a estimação por modelo de regressão mesclado, com erros-padrão } \\
\text { robustos com agrupamento por indivíduo; Cluster2 é a estimação com agrupamento por indivíduo e por período; } \\
\text { BE é a estimação between, ou entre as empresas; EF Rob é o modelo com efeitos fixos com erros-padrão robustos; } \\
\text { e EA Rob é o modelo com efeitos aleatórios com erros-padrão robustos. } \\
\text { *variável significativa a 10\%; ** variável significativa a 5\%; e *** variável significativa a 1\% }\end{array}$} \\
\hline
\end{tabular}

Fonte: Autor

\subsection{População segmentada por tamanho}

No decorrer dos testes realizados, uma preocupação que surgiu foi com uma possível existência de multicolinearidade entre a variável de interesse "Publicações" e a variável de 
controle "Tamanho", que no estudo foi calculada a partir do ativo total das empresas pesquisadas.

Essa correlação mais alta já era esperada entre essas variáveis explicativas, associando um número de publicações maior a empresas de grande porte, já que existe uma orientação editorial dos veículos de comunicação de priorizar a cobertura de grandes empresas, com maior impacto na economia do país e na vida das pessoas. Além disso, grandes empresas possuem equipes de comunicação mais bem aparelhadas para buscar espaço na mídia. Ressalta-se que outros parâmetros de tamanho foram testados, como a Receita e o Patrimônio Líquido, porém tal situação na matriz de correlação se manteve.

Foi realizado o teste VIF, que mede a correlação multivariada entre os parâmetros $x$ da equação de regressão, indicando valor máximo de 3,20 (abaixo de 5, portanto), o que segundo alguns autores, como Fávero (2015), já seria suficiente para relevar o problema de multicolinearidade.

Existe outro entendimento, contudo, de que a análise de multicolinearidade pode ser mais bem verificada na matriz de correlações (Gujarati, 2006). Isso porque é ali que pode ser constatado se a correlação de uma variável explicativa junto à variável dependente se apresenta em patamar inferior às respectivas correlações entre as próprias variáveis explicativas, ensejando em multicolinearidade.

Assim, analisou-se a matriz de correlação das variáveis que aparecem na Tabela 15:

Tabela 15. Matriz de correlação das variáveis da Equação 4 e 6

\begin{tabular}{l|ccccccc}
\hline & P/VPA & Liquidez & Publicações & Retorno & Cresc. & Endiv. & Tamanho \\
\hline P/VPA & 1,000 & & & & & & \\
Liquidez & 0,218 & 1,000 & & & & & \\
Publicações & 0,048 & 0,709 & 1,000 & & & & \\
Retorno & 0,651 & 0,107 & 0,044 & 1,000 & & & \\
Crescimento & 0,138 & 0,058 & $-0,026$ & 0,070 & 1,000 & & \\
Endividamento & 0,004 & 0,037 & 0,242 & 0,010 & $-0,074$ & 1,000 & \\
Tamanho & $-0,187$ & 0,650 & 0,785 & $-0,077$ & $-0,067$ & 0,407 & 1,000 \\
\hline
\end{tabular}

Nota: P/VPA é o logaritmo da relação entre o valor de mercado da empresa dividido pelo seu valor patrimonial; Liquidez é o logaritmo da medida Liquidez em bolsa cujo cálculo está descrito na equação 3 do item 3.2 deste trabalho; Publicações é o número de matérias em que cada empresa é citada por trimestre no jornal Valor; Retorno é a rentabilidade sobre o patrimônio líquido de cada empresa; Crescimento é a variação da receita em 12 meses; Endividamento é a razão entre o exigível total e o ativo total da empresa; e Tamanho é o logaritmo natural do ativo total da empresa em milhares de reais.

Fonte: Autor 
Nota-se que, além da correlação elevada, de 78,5\% entre as variáveis explicativas "Publicações" e "Tamanho", esse valor é bastante superior à correlação entre a variável de interesse "Publicações" e a variável dependente "P/VPA", de 4,8\%, usada na Equação 4. No caso da Equação 6, que tem "Liquidez" como variável dependente, o mesmo problema não ocorre. Isso porque a correlação entre "Publicações" e "Liquidez", de 70,9\%, é maior que a existente entre "Liquidez" e "Tamanho", de 65,0\%.

Já para analisar o caso da Equação 5, que tem “ $Q$ de Tobin” como variável dependente, é apresentada uma matriz de correlação separada, na Tabela 16, já que ela reúne um universo menor e, portanto, diferente de empresas. Contudo, o mesmo indício de multicolinearidade se repete, com a correlação entre a variável "Publicações" sendo muito maior com a variável de controle "Tamanho", de 74,32\%, do que com a variável explicada " $Q$ de Tobin", em 6,83\%.

Tabela 16. Matriz de correlação das variáveis da Equação 5

\begin{tabular}{|c|c|c|c|c|c|c|}
\hline & $Q$ de Tobin & Publicações & Retorno & Crescimento & Endividamento & Tamanho \\
\hline$Q$ de Tobin & 1,0000 & & & & & \\
\hline Publicações & 0,0683 & 1,0000 & & & & \\
\hline Retorno & 0,5927 & 0,0305 & 1,0000 & & & \\
\hline Crescimento & 0,1549 & $-0,0034$ & 0,0838 & 1,0000 & & \\
\hline Endividamento & $-0,1607$ & 0,1353 & 0,0062 & $-0,0147$ & 1,0000 & \\
\hline Tamanho & $-0,1820$ & 0,7432 & $-0,1244$ & $-0,0362$ & 0,2543 & 1,0000 \\
\hline \multicolumn{7}{|c|}{$\begin{array}{l}\text { Notas: Q de Tobin é o logaritmo da medida de avaliação, cujo calculo está detalhado no item 3.x; Publicações é o } \\
\text { logaritmo natural do número de matérias em que cada empresa é citada por trimestre no jornal Valor; Retorno é a } \\
\text { rentabilidade sobre o patrimônio líquido de cada empresa; e Tamanho é o logaritmo natural do ativo total da } \\
\text { empresa em milhares de reais. }\end{array}$} \\
\hline
\end{tabular}

Fonte: Autor

Cabe notar que alguns autores só veem risco nessa situação quando há a coexistência de uma correlação elevada entre variáveis explicativas e um $\mathrm{R}^{2}$ também muito alto, o que não ocorre nos modelos testados, já que o poder explicativo total do modelo fica em 30,2\% para "P/VPA" e em 38,9\% para " $Q$ de Tobin" nos testes com efeitos fixos, que foram considerados os mais adequados. Além disso, os modelos foram construídos para diagnóstico da situação existente no período analisado, e não para serem usados para prever o comportamento de valor de mercado das empresas no futuro, o que reduz a relevância desse problema.

De qualquer forma, para reforçar as conclusões e entender melhor a relação entre as variáveis, optou-se por um teste adicional, apenas com a variável "P/VPA", por ser a principal 
do estudo, em que se usou a própria variável de controle "Tamanho" para segmentar a amostra em quatro grupos e analisar as variáveis dentro das faixas de ativo especificadas pelos quartis.

Dessa forma, a amostra total de 152 empresas foi subdividida em quatro grupos de empresas, que foram chamados de Pequenas, Médias Baixas, Médias Altas e Grandes. Cada subgrupo ficou com um quarto das empresas da amostra, ou 38 companhias, resultando em um total máximo de 760 observações por grupo (38 empresas em 20 trimestres), sem considerar a existência de missing values. Ver detalhes na Tabela 17: 
Tabela 17. Empresas segmentadas por quartis, a partir do porte

\begin{tabular}{|c|c|c|c|}
\hline Pequenas & Médias Baixas & Médias Altas & Grandes \\
\hline $\begin{array}{c}\text { Ativo médio } \\
\text { abaixo de } \mathrm{R} \$ 1,75 \\
\text { bilhão }\end{array}$ & $\begin{array}{l}\text { Ativo médio entre } \\
\text { R\$ 1,75 bilhões a } R \$ \\
4,02 \text { bilhões }\end{array}$ & $\begin{array}{l}\text { Ativo médio entre } \\
R \$ 4,03 \text { bilhões a } \\
R \$ 12,18 \text { bilhões }\end{array}$ & $\begin{array}{c}\text { Ativo médio } \\
\text { acima de } \mathrm{R} \$ 12,29 \\
\text { bilhões }\end{array}$ \\
\hline Eucatex & Paranapanema & Hypermarcas & Banco do Brasil \\
\hline Log-In & Minerva & Light energia & Itaú \\
\hline Romi & Localiza & Eletropaulo & Bradesco \\
\hline Estácio & Even & Via Varejo & Petrobras \\
\hline Totvs & Dasa & BR Properties & Santander \\
\hline Trisul & SLC & Pine & Eletrobras \\
\hline $\mathrm{IMC}$ & Sonae Sierra & Tereos & Oi \\
\hline Mills & Marcopolo & Biosev & $\mathrm{JBS}$ \\
\hline Profarma & Tupy & MRV & Gerdau \\
\hline Multiplus & Iguatemi & Weg & Ambev \\
\hline Providência & Coelce & Gafisa & CSN \\
\hline Ferbasa & JHSF & Copasa & Banrisul \\
\hline BHG & Helbor & BB Seguridade & Braskem \\
\hline Hering & M. Dias Branco & Cielo & Cemig \\
\hline Locamerica & Renner & Cteep & Pão de Açúcar \\
\hline Odontoprev & Aliansce & Duratex & Usiminas \\
\hline Valid & Qualicorp & Taesa & BRF \\
\hline Metalfrio & HRT & Alupar & Fibria \\
\hline Tegma & Alpargatas & Arteris & CPFL \\
\hline Le Lis Blanc & Direcional & Equatorial & Sabesp \\
\hline Fras-le & Heringer & Magnesita & Cosan \\
\hline Brasil Brokers & QGEP & Celesc & Suzano \\
\hline BrasilAgro & Mahle & Ecorodovias & Marfrig \\
\hline Eternit & Raia Drogasil & Souza Cruz & Copel \\
\hline Portobello & Cetip & Multiplan & Embraer \\
\hline Ideiasnet & Marisa & São Martinho & Cesp \\
\hline CR2 & Abril Educação & B2W & BicBanco \\
\hline Time For Fun & Brasil Pharma & Magazine Luiza & PDG \\
\hline Kepler & $\mathrm{CCP}$ & JSL & BR Malls \\
\hline $\operatorname{Lin} x$ & Grendene & Indusval & Ultrapar \\
\hline Brasil Insurance & Santos Brasil & lochpe & Klabin \\
\hline Technos & Contax & Randon & Sul América \\
\hline Arezzo & EZTec & Paraná Banco & ABC Brasil \\
\hline Bematech & Vanguarda Agro & AES Tietê & CCR \\
\hline CSU & Rodobens & Triunfo & Cyrela \\
\hline Unicasa & CVC & Kroton & Energias do Brasil \\
\hline Renar & São Carlos & Sofisa & Daycoval \\
\hline Tarpon & General Shopping & Tecnisa & Tractebel \\
\hline
\end{tabular}


Com isso, conforme a legenda a seguir, observou-se novamente a matriz de correlação para os quatro subgrupos, na Tabela 18, prevalecendo indícios de multicolinearidade somente no subgrupo Grandes, que reúne as maiores empresas por ativos totais.

Tabela 18. Matriz de correlação das variáveis da Equação 4 e 6, com quebra por porte

Legenda:

\begin{tabular}{|c|c|c|c|c|c|c|c|c|c|c|c|c|}
\hline \multirow{2}{*}{\multicolumn{2}{|c|}{$\begin{array}{c}\text { Grandes } \\
\text { Médias Baixas }\end{array}$}} & \multicolumn{3}{|c|}{ Médias Altas } & & & & & & & & \\
\hline & & \multicolumn{3}{|c|}{ Pequenas } & & & & & & & & \\
\hline & \multicolumn{2}{|c|}{ P/VPA } & \multicolumn{2}{|c|}{ Publicações } & \multicolumn{2}{|c|}{ Retorno } & \multicolumn{2}{|c|}{ Cresc. } & \multicolumn{2}{|c|}{ Endiv. } & \multicolumn{2}{|c|}{ Tamanho } \\
\hline \multirow{2}{*}{ P/VPA } & 1,00 & 1,00 & & & & & & & & & & \\
\hline & 1,00 & 1,00 & & & & & & & & & & \\
\hline \multirow{2}{*}{ Publicações } & $-0,05$ & 0,30 & 1,00 & 1,00 & & & & & & & & \\
\hline & 0,28 & 0,45 & 1,00 & 1,00 & & & & & & & & \\
\hline \multirow{2}{*}{ Retorno } & 0,65 & 0,71 & 0,02 & 0,18 & 1,00 & 1,00 & & & & & & \\
\hline & 0,46 & 0,71 & $-0,00$ & 0,28 & 1,00 & 1,00 & & & & & & \\
\hline \multirow{2}{*}{ Cresc. } & 0,11 & 0,16 & $-0,04$ & 0,01 & 0,20 & 0,05 & 1,00 & 1,00 & & & & \\
\hline & $-0,03$ & 0,22 & $-0,19$ & 0,10 & $-0,12$ & 0,16 & 1,00 & 1,00 & & & & \\
\hline \multirow{2}{*}{ Endiv. } & 0,14 & $-0,00$ & 0,18 & 0,04 & 0,12 & $-0,02$ & $-0,01$ & $-0,12$ & 1,00 & 1,00 & & \\
\hline & 0,14 & 0,05 & $-0,13$ & $-0,20$ & $-0,09$ & 0,09 & $-0,06$ & $-0,08$ & 1,00 & 1,00 & & \\
\hline \multirow{2}{*}{ Tamanho } & $-0,09$ & $-0,12$ & 0,81 & 0,35 & 0,06 & $-0,06$ & $-0,09$ & $-0,03$ & 0,33 & $-0,04$ & 1,00 & 1,00 \\
\hline & $-0,08$ & $-0,19$ & 0,15 & 0,06 & $-0,02$ & $-0,31$ & $-0,25$ & 0,08 & 0,17 & 0,05 & 1,00 & 1,00 \\
\hline
\end{tabular}

Nota: P/VPA é o logaritmo da relação entre o valor de mercado da empresa dividido pelo seu valor patrimonial; Liquidez é o logaritmo da medida Liquidez em bolsa cujo cálculo está descrito na equação 3 do item 3.2 deste trabalho; Publicações é o número de matérias em que cada empresa é citada por trimestre no jornal Valor; Retorno é a rentabilidade sobre o patrimônio líquido de cada empresa; Crescimento é a variação da receita em 12 meses; Endividamento é a razão entre o exigível total e o ativo total da empresa; e Tamanho é o logaritmo natural do ativo total da empresa em milhares de reais.

Fonte: Autor

Como se nota, as correlações entre "Publicações" e "Tamanho" nos subgrupos Grandes, Médias Altas, Médias Baixas e Pequenas foram respectivamente de 81,2\%, 35,1\%, 14,7\% e $5,6 \%$, mostrando, portanto, uma trajetória decrescente quanto menor as empresas.

Já as correlações entre a variável de interesse "Publicações" e a variável dependente "P/VPA" mostraram comportamento distinto. Ficou negativa em 5\% no subgrupo das grandes empresas, próxima de 30\% nos estratos Médias Altas e Médias Baixas, e subiu a 45\% entre as pequenas empresas. 
Uma compreensão melhor dessa diferença de resultados se dá pela observação dos quatro gráficos da Figura 13.

Figura 13. Comparação da correlação entre P/VPA e Publicações, por porte

\section{Grandes}

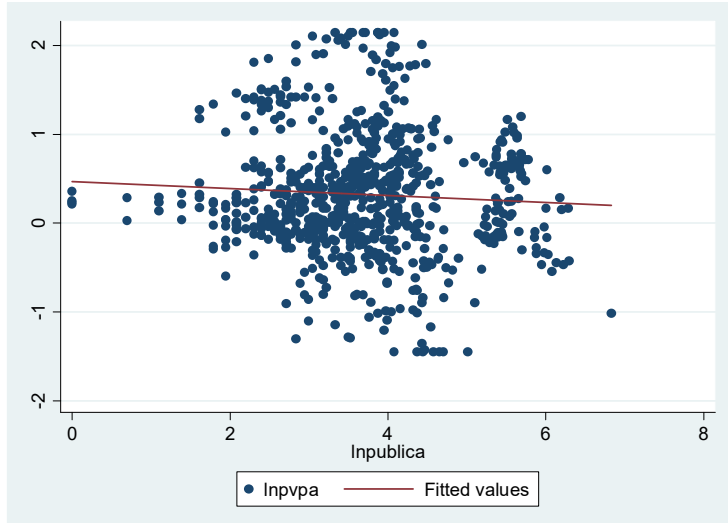

Médias Baixas

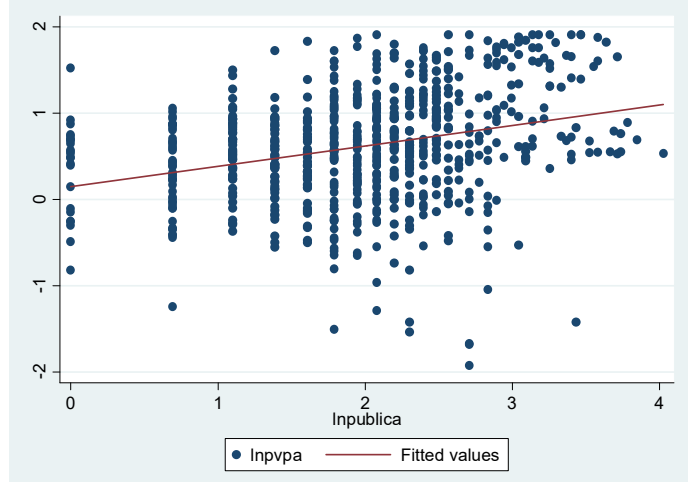

Médias Altas

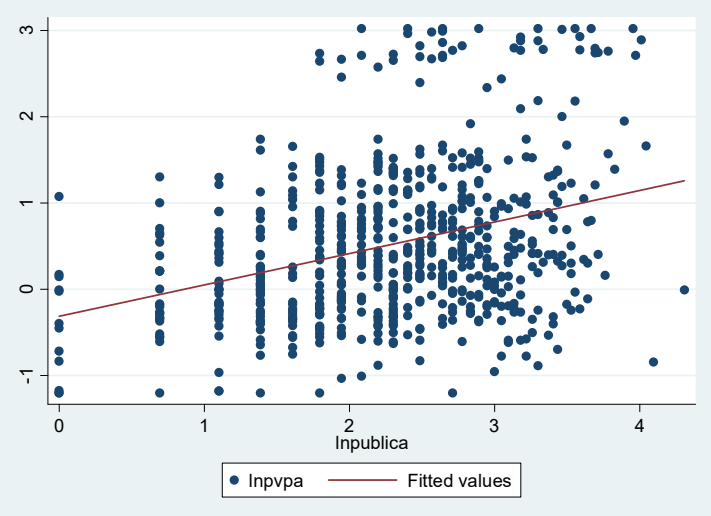

Pequenas

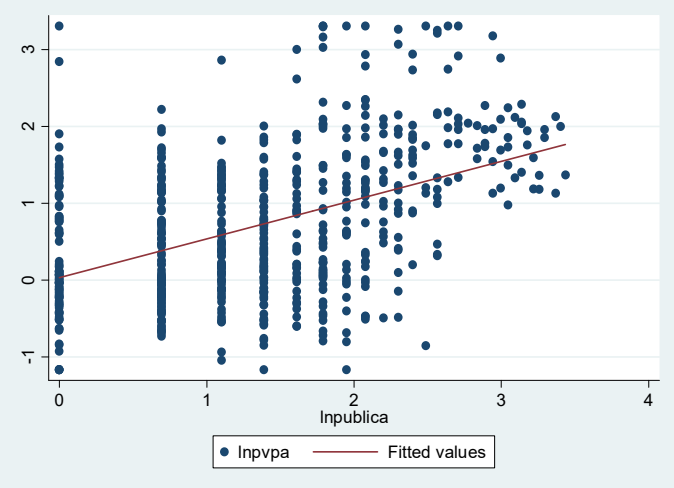

Fonte: Autor

Os gráficos retirados do software Stata mostram que nos três quartis com as empresas pequenas e médias, há uma relação positiva entre a variável que mede a intensidade da cobertura da mídia com a variável que mensura o valor de mercado das empresas, conforme esperado pela teoria. Já entre as grandes empresas, a relação é contrária. O gráfico apresentado na Figura 14, que junta os três primeiros quartis - deixando apenas as grandes empresas de fora -, corrobora essa análise. 
Figura 14. Correlação entre P/VPA e Publicações, três primeiros quartis

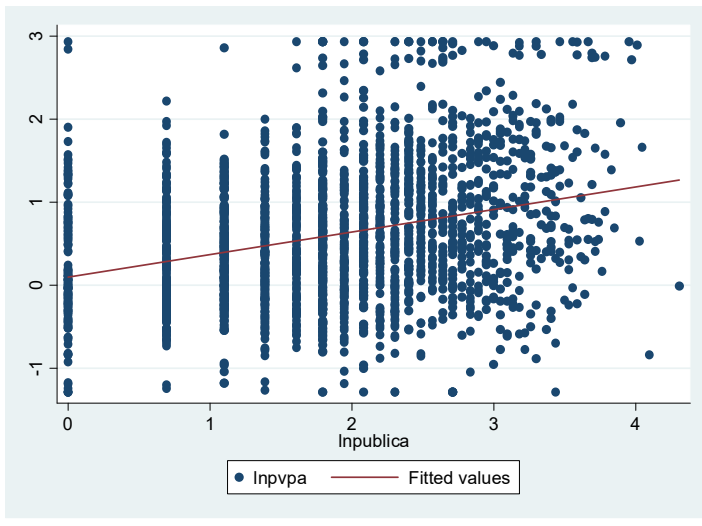

Fonte: Autor

Na aplicação dos modelos estatísticos com a amostra segregada em quartis a partir do porte das companhias, os mesmos procedimentos da primeira etapa foram realizados quanto aos testes de Chow, LM de Breusch Pagan e Schalfer e Stillman (equivalente ao teste robusto de Hausman), que indicaram novamente o uso do modelo de regressão com Dados em Painel com efeitos fixos. O resumo dos resultados é mostrado na Tabela 19 para a variável dependente "P/VPA".

Conforme os resultados, a estatística $\mathrm{F}$ e seu respectivo p-valor indicam que, com um nível de confiança de $99 \%$, é possível rejeitar a hipótese nula de que todos os parâmetros testados - a saber, "Publicações", "Retorno", "Crescimento", "Endividamento" e "Tamanho" - tenham beta estatisticamente iguais a zero para explicar a variável dependente "P/VPA". Ou seja, esse teste indica que pelo menos um parâmetro é estatisticamente diferente de zero nos quatro quartis avaliados.

Contudo, quando se analisa as estatísticas t de cada parâmetro, nota-se um comportamento distinto entre os subgrupos. Entre grandes empresas, apenas a variável "Retorno" se mostrou estatisticamente significativa, ao nível de 1\%. Todas as demais, incluindo a variável de interesse "Publicações", perderam a relevância estatística. Um ponto que chama a atenção no caso das grandes empresas é que o sinal do teste estatístico, que considera a presença das demais variáveis, ficou positivo, ao contrário do que ocorreu na análise da correlação simples e direta com a variável "P/VPA". 
Tabela 19. Regressão robusta com dados em painel com efeitos fixos, para variável dependente P/VPA, por quartil de Tamanho, do menor para o maior

\begin{tabular}{|c|c|c|c|c|}
\hline P/VPA & Pequenas & Médias Baixas & Médias Altas & Grandes \\
\hline Publicações & $0,096 * * *$ & $0,078 * * *$ & $0,085^{* *}$ & 0,037 \\
\hline Erro-padrão & 0,03 & 0,026 & 0,039 & 0,046 \\
\hline Retorno & $0,006 * *$ & 0,004 & $0,009 * *$ & $0,014 * * *$ \\
\hline Erro-padrão & 0,003 & 0,007 & 0,004 & 0,003 \\
\hline Crescimento & 0,002 & 0,000 & $0,003 * * *$ & 0,001 \\
\hline Erro-padrão & 0,001 & 0,001 & 0,008 & 0,001 \\
\hline Endividamento & $0,009 * * *$ & $0,017 * *$ & $0,014^{*}$ & 0,006 \\
\hline Erro-padrão & 0,003 & 0,006 & 0,008 & 0,005 \\
\hline Tamanho & $-0,312^{*}$ & $-0,254^{* *}$ & $-0,222 *$ & $-0,196$ \\
\hline Erro-padrão & 0,165 & 0,122 & 0,12 & 0,117 \\
\hline Constante & $4,256^{*}$ & $3,290 *$ & $2,699 *$ & 3,029 \\
\hline Erro-padrão & 2,223 & 1,745 & 1,511 & 1,896 \\
\hline \multicolumn{5}{|l|}{$\mathrm{R}^{2}$} \\
\hline Dentro & 0,1798 & 0,147 & 0,243 & 0,185 \\
\hline Entre & 0,3675 & 0,18 & 0,31 & 0,315 \\
\hline Total & 0,3637 & 0,106 & 0,353 & 0,288 \\
\hline Estatística F & $8,22 * * *$ & $5,82 * * *$ & $8,07 * * *$ & $5,93 * * *$ \\
\hline Observações & 556 & 648 & 646 & 746 \\
\hline \multicolumn{5}{|c|}{ 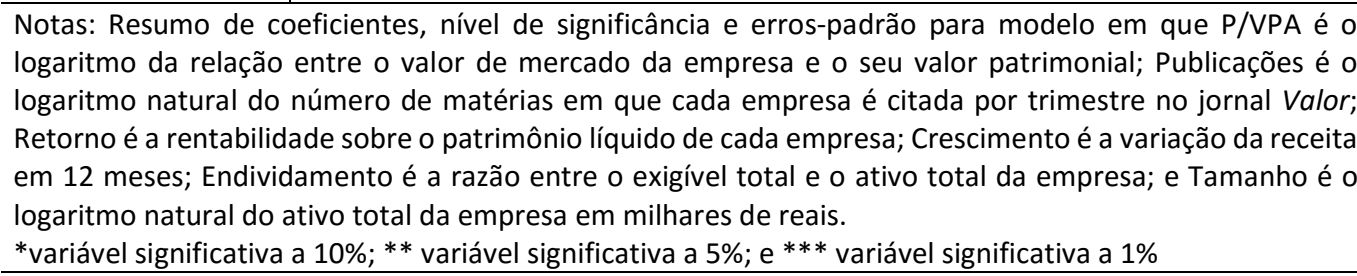 } \\
\hline
\end{tabular}

Nos três demais quartis, o parâmetro que procurou medir a cobertura da mídia se mostrou estatisticamente significante, ao nível de confiança de 95\%, para explicar a variância do valor de mercado das empresas analisadas durante esse período. Os coeficientes também ficaram próximos, em 0,096 para as pequenas empresas, em 0,078 para as Médias Baixas e em 0,085 para Médias Altas.

Em termos de poder explicativo, o $\mathrm{R}^{2}$ Total ficou próximo de $35 \%$ para os subgrupos das Pequenas e das Médias Altas, caindo para 10,6\% no estrato das Médias Baixas.

Esses dados sugerem que a exposição viabilizada pela mídia perde poder explicativo entre as grandes companhias, talvez porque elas já sejam suficientemente conhecidas do público - 
com o papel da imprensa agregando menos novidade - e/ou pelo fato de elas já serem extensamente seguidas por analistas de mercado.

De forma geral, é possível dizer que o resultado da análise da amostra por quartis corrobora estudo de Lima (2013), que estudou a correlação entre a cobertura de analistas e o valor de mercado das empresas. $O$ autor notou que a entrada de um novo analista para acompanhar uma empresa tem poder maior para afetar seu valor de mercado quando existem menos analistas cobrindo aquela companhia no momento anterior. Ou seja, para a empresa que tem nove analistas que a acompanham, é menos relevante ganhar o décimo analista do que, para aquela que tem quatro profissionais a seguindo, ganhar o quinto especialista.

\subsection{Análise dos principais resultados}

Após a realização de inúmeros testes estatísticos, com diferentes técnicas, mudança de variáveis e abordagens distintas, chega o momento de se confrontar os resultados obtidos com as hipóteses de pesquisa levantadas no Capítulo 1, a partir do problema de pesquisa delimitado.

A primeira proposta era testar se existe relação estatisticamente significante e positiva entre a cobertura que a mídia faz de uma empresa e seu valor de mercado. Para tal, foram construídos modelos empíricos em que se usou a frequência de citações do nome das empresas como proxy de acompanhamento da companhia pela imprensa. Do outro lado da equação, foram usadas duas medidas clássicas de avaliação por múltiplo: "P/VPA" e " $Q$ de Tobin". Em ambos os casos, sem que se trate de causa e efeito, os testes indicaram que não é possível negar que haja relação estatisticamente relevante entre o acompanhamento da imprensa e o valor de mercado das companhias no período avaliado.

É importante destacar, contudo, que quando a amostra foi dividida em quartis, verificouse que essa relação positiva não se confirmou para o subgrupo que concentrou as maiores empresas por ativos. Isso indica que, na amostra e o no período anlisados, a exposição viabilizada pela mídia perdeu poder para explicar o valor de mercado das companhias quando elas eram de grande porte.

A segunda proposta foi verificar se há relação estatisticamente significante entre a exposição que as companhias têm na mídia econômica especializada e o nível de liquidez de 
suas ações. Ou seja, se é possível dizer (ou se não se pode negar) que quanto maior o acompanhamento de uma empresa por jornalistas, maior o volume de negócios com ações dessa companhia - mais uma vez, sem se falar em causa e efeito. A frequência de citação de cada empresa foi usada para medir a intensidade da cobertura da mídia, enquanto o índice de Liquidez em bolsa entrou no modelo empírico como variável dependente. Os diversos testes realizados indicam que não é possível rejeitar a hipótese de que haja relação estatisticamente significante entre essas variáveis na amostra e período avaliados.

Desta forma, o resumo abaixo explicita os resultados obtidos.

Hipótese 1: Existe relação estatisticamente significante e positiva entre a frequência de cobertura de uma empresa na mídia e seu valor de mercado?

\section{Não rejeitada}

Hipótese 2: Existe relação significante e positiva entre a frequência de cobertura de uma empresa na mídia e a liquidez de suas ações?

\section{Não rejeitada}




\section{CONCLUSÕES E CONSIDERAÇÕES FINAIS}

O objetivo deste trabalho foi, a partir do pressuposto de que a cobertura da imprensa pode ser um vetor de redução da assimetria de informação sobre companhias abertas, identificar eventuais relações positivas e estatisticamente significantes da exposição de empresas na mídia econômica especializada com valor de mercado e liquidez de suas ações.

Os resultados encontrados corroboram a teoria e a evidência de estudos internacionais e levam à conclusão de que a frequência de publicações sobre as empresas da amostra na mídia econômica brasileira está associada, ao longo do tempo, com uma maior valorização e também com aumento de liquidez de suas ações. Em outras palavras, os diversos testes estatísticos aplicados apontaram que, quanto maior acompanhamento feito por jornalistas, maior o valor da empresa e maior a liquidez de suas ações. E a conclusão vale tanto para a comparação entre as 152 companhias pesquisadas como também para as mesmas empresas, ao longo dos 20 trimestres entre o início de 2010 e o fim de 2014, o que mostra a relevância de se gerenciar essa exposição.

Respondendo tecnicamente à questão de pesquisa colocada na Introdução, os resultados encontrados não permitem que se rejeite, com um nível de confiança de $99 \%$, a hipótese de que a cobertura da imprensa afeta o valor de mercado das companhias estudadas e/ou o volume de negócios com suas ações no período analisado.

A transformação da variável de interesse "Publicações" em logaritmo natural não facilita a tradução quantitativa dos resultados, para explicitar o poder explicativo da variável. Mas é importante destacar que os sinais dos coeficientes foram positivos e similares quando se analisou a relação com valor de mercado, seja por meio da variável dependente "P/VPA", ficando em 0,081 , seja com o " $Q$ de Tobin", em 0,070 .

$\mathrm{Na}$ análise da relação entre a cobertura da mídia e liquidez das ações, o coeficiente ficou ainda mais forte, em 0,199, mostrando um poder explicativo maior nesse segundo caso.

Um achado importante do estudo foi que, ao se dividir a amostra em quatro subgrupos a partir do porte das companhias, perdeu-se a relação estatisticamente significante entre a cobertura da mídia e o valor de mercado das grandes empresas, que no corte deste trabalho incluiu aquelas com ativos totais médios acima de R\$ 12 bilhões neste período. Ou seja, a relação estatística foi comprovada para as pequenas e médias empresas que integraram os 
primeiros três quartis da amostra, mas não para as maiores companhias. Uma hipótese para essa diferença de comportamento, se houvesse relação causal comprovada (o que o estudo não se propôs a provar), estaria no fato de elas já serem suficientemente conhecidas do público investidor e/ou pelo fato de elas já serem extensamente seguidas por analistas de mercado com o papel da imprensa de reduzir a assimetria informacional sendo menos relevante.

Mais uma vez, sem a pretensão de estabelecer uma relação de causa e efeito, mas tendo como base as evidências encontradas de associação estatisticamente significante e também a literatura internacional que já tratou desse tema, lista-se abaixo algumas possíveis razões que poderiam justificar a existência dessa relação positiva entre cobertura de imprensa, valor de mercado e liquidez.

1 - A mídia potencializa o alcance de divulgações oficiais das companhias. Há centenas de empresas na bolsa e, ainda que a página de relações com investidores (RI) das empresas e o site a CVM possam ser acessados por qualquer pessoa com um computador conectado a internet, não há tempo hábil para que investidores façam esse monitoramento sozinhos todos os dias. Mesmo os serviços de alerta por e-mail dos sites de RI só funcionam depois que a pessoa já visitou a página da empresa pela primeira vez e se cadastrou, mas não alcança todos os investidores potenciais. No mercado financeiro, quem cumpre o papel de intermediário da informação entre as companhias abertas e o mercado de forma mais ampla são os analistas de sell-side e a mídia econômica especializada, que selecionam e hierarquizam quais empresas serão mais acompanhadas, quais informações serão propagadas e qual destaque cada notícia terá nos relatórios de análise e nos veículos de comunicação, sejam eles impressos ou eletrônicos.

2 - Empresas com ações mais líquidas - ou com ações que vão ganhando liquidez com o tempo - atraem maior cobertura de analistas e também de jornalistas. E empresas com maior cobertura de analistas e jornalistas ficam mais em evidência e também ganham mais liquidez. Assim, essa relação cria um círculo virtuoso que reduz a assimetria de informação referente a essas companhias, melhora a formação de preço e esses dois fatores se refletem também no seu valor de mercado. Contudo, embora esse efeito de retroalimentação seja perene em relação a volume de negócios, acaba perdendo poder explicativo sobre o valor das companhias a partir do momento em que elas se tornam "gigantes" e amplamente conhecidas no mercado, com o efeito marginal de uma exposição adicional na mídia sendo menos relevante. 
3 - A cobertura da imprensa cria uma espécie de efeito Top of Mind, termo usado no mercado publicitário que se refere às marcas mais lembradas pelas pessoas em cada segmento, como Coca-Cola para refrigerantes, OMO para sabão em pó e assim por diante. Ao ter exposição frequente na imprensa, algumas empresas se tornam a referência (ou as referências) quando se fala de um setor, como o caso da Lojas Renner na área de varejo de vestuário. $\mathrm{O}$ mesmo se aplica a outros segmentos, como o de incorporação imobiliária, que tem algumas dezenas de empresas listadas e com características semelhantes. Uma possibilidade é que a mídia influencie de alguma forma tanto o investidor individual como também os gestores e alocadores de recursos a pensarem nessas empresas mais conhecidas quando procuram uma exposição a determinado setor, a partir de um processo de seleção top down, por exemplo, em que se sai do ambiente macro global, em seguida para o país, depois para o setor a apenas na última etapa se escolhe a empresa e a ação que será adquirida. Empresas mais populares, mais líquidas, mais transparentes e mais acompanhadas por analistas e jornalistas podem entrar no radar de maneira mais automática nesses casos.

Mais uma vez, não se pretende aqui dizer que a cobertura da mídia é o único e principal fator a explicar o valor de mercado ou a liquidez das ações de uma empresa. Mas um elemento adicional, entre outros já identificados na literatura, que carrega algum poder explicativo, mantido tudo mais constante.

De maneira geral, espera-se que os resultados encontrados neste trabalho possam contribuir para uma relação mais bem informada entre companhias, assessorias de imprensa, veículos de comunicação e reguladores, que atualmente estabelecem suas relações com base em crenças sobre possíveis impactos e resultados de seus trabalhos, mas nem sempre medem o real alcance daquilo que fazem.

Apesar de os achados serem animadores para uma primeira pesquisa na área no Brasil, cabe destacar a existência de limitações ao trabalho. Entre elas destaca-se o período de 20 trimestres, que pode ser considerado curto (apesar da utilização de Dados em Painel que possibilitou quase 3.000 observações empresa-trimestre) e o direcionamento apenas associativo entre a variável de interesse e as variáveis dependentes pesquisadas, sem que se estabeleça uma relação de causa e efeito.

Outra dúvida ou crítica que pode surgir é se o que tem relação com o valor de mercado e a liquidez das ações da empresa é a cobertura da mídia feita pela mídia em si, ou se o conteúdo daquilo que é reportado. 
De fato, essa é uma questão difícil de responder e também difícil de rejeitar a priori.

Mas o modelo usado neste trabalho procurou tratar esse problema de algumas formas. Em primeiro lugar, não foi realizado um estudo de evento, em que se mede a reação imediata da ação a uma determinada notícia ou informação em intervalo de poucos dias ou horas. Se o modelo fosse esse, o risco mencionado seria maior. Neste trabalho, avaliou-se a relação entre a frequência de cobertura da mídia e o valor da empresa e a liquidez de suas ações ao longo de 20 trimestres, um período suficientemente longo para que a novidade das notícias em si seja incorporada aos preços.

Além disso, para que a crítica fosse realmente verdadeira, seria preciso acreditar que há um viés dos jornalistas e das empresas de mídia em escrever mais matérias sobre empresas que têm apenas boas notícias para contar. Mas a prática e os dados recentes de Petrobras e Oi mostram não só que isso não é verdade como também evidenciam que, se existe algum viés de orientação na mídia, ele tem sentido contrário, procurando ressaltar pontos negativos ou conflitos existentes nas companhias.

A favor dessa crítica, existe o fato de que a amostra foi escolhida a partir de empresas que integravam pelo menos um índice calculado e divulgado pela BM\&FBovespa, o que retirou da base (de forma não proposital) companhias em processo de recuperação judicial, mas que tiveram grande exposição na imprensa nesse período, como as empresas do Grupo X, do empresário Eike Batista.

Para futuros trabalhos, sugere-se o aumento do período de tempo analisado e também avaliação de critérios qualitativos sobre a exposição das empresas na mídia. Ou seja, seria interessante incluir nos modelos dados indicando se a matéria publicada na imprensa sobre a empresa foi positiva, neutra ou negativa, e também a proeminência ou destaque que a empresa teve na notícia ou reportagem publicada. Afinal, é de se esperar que uma sequência de publicações do nome de uma empresa nos títulos de matérias de capa com abordagens negativas tenham efeito distinto de uma série de notas neutras ou positivas no "pé" de páginas internas dos jornais.

Recomenda-se ainda que novas pesquisas façam testes com o objetivo de se provar ou de se rejeitar a causalidade entre a cobertura da mídia e o valor de mercado e liquidez das ações das empresas. Aparentemente, se ratificada essa relação causal, a busca por maior cobertura da imprensa se mostraria até mais relevante para médias e pequenas empresas que, com exposição 
pública inferior às de grande porte, reduziriam em maior proporção a assimetria informacional existente entre sua administração e seus públicos de interesse, inclusive investidores, e poderiam assim alavancar o preço de suas ações e a sua liquidez.

Qualquer comprovação de causa e efeito também se mostrará relevante para empresas e profissionais de assessoria de imprensa, que poderão colocar isso no preço cobrado pelo seu serviço. De maneira indireta, o mesmo vale para veículos de imprensa, que em tese podem se beneficiar de estudos empíricos que reforcem o que hoje é apenas uma percepção ou suposição sobre seu poder de influenciar o comportamento de investidores. 


\section{REFERÊNCIAS}

Aberje. (2012). Pesquisas de comunicação. Fonte: Associação Brasileira de Comunicação Empresarial: http://www.aberje.com.br/pesquisa/PesquisaFornecedComunic2012.pdf?mode=embed\&do cumentld=090213145019-1be6f2e452fe4527a7cb52950ac5caad\&layout=grey

Akerlof, G. A. (1970). Ther Market for Lemons: Quality Uncertainty and the Market Mechanism. Quaterly Journal of Economics 84 (3), pp. 488-500.

ANJ. (2015). Maiores jornais do Brasil. Fonte: Associação Nacional dos Jornais: http://www.anj.org.br/maiores-jornais-do-brasil/

Arbel, A., Carvell, S., \& Strebel, P. (1983). Giraffes, institutions and neglected firms. Financial Anlysts Journal, May/June, pp. 2-8.

Barber, B. M., \& Odean, T. (2008). All that Glitters: teh effect of Attention and news on the Buying Behavior of Individual and Institucional Investors. Review of Financial Studies, 21 (2), pp. 785818.

Blouin, M. C. (2010). What types of firms send a clear signal in the MD\&A? Journal of Academy of Business and Economics.

BM\&FBovespa. (2015). MBA para jornalistas. Fonte: http://www.bmfbovespa.com.br/sala-deimprensa/MBAJornalistas.aspx?Idioma=pt-br

Bowen, R. M., Davis, A. K., \& Matsumoto, D. A. (2005). Emphasis on Pro Forma versus GAAP Earnings in Quarterly Press Releases: Determinants, SEC Intervention, and Market Reactions. The Accouting Review.

Brown, N. C., Christensen, T. E., \& Elliot, W. B. (2012). The timing of Quarterly 'Pro Forma' Earnings Announcement. Journal of Business Finance \& Accounting.

Bruni, A. L., \& Famá, R. (2000). Liquidez e avaliação de ativos financeiros. Seminários de Administração FEA-USP, 3. São Paulo.

Cao, H. H., Han, B., Hirshleifer, D., \& Zhang, H. H. (2011). Fear of the Unknown: Familiarity and Economic Decisions. Review Of Finance, 15 (1), pp. 173-206.

Chan, K., Covrig, V., \& Ng, L. (2005). What Determines the Domestic Bias and Foreign Bias? Evidence from Mutual Fund Equity Allocations Worldwide. Journal of Finance, 60 (3), pp. 1495-1534.

Chan, W. S. (2002). Stock Price Reaction to News and No-News: Drift and Reversal After Headlines. Draft.

CPC - Comitê de Pronunciamentos Contábeis. (2011). PRONUNCIAMENTO CONCEITUAL BÁSICO (R1).

Davis, A. K., \& Tama-Sweet, I. (2012). Managers's Use of Language Across Alternative Disclosure Outlets: Earnings Press Release versus MD\&A. Contemporary Accounting Research. 
Davis, A. K., Piger, J. M., \& Sedor, L. M. (2012). Beyond the Numbers: Measuring the Information Content of Earnings Press Releas Language. Contemporary Accounting Research.

Dias Filho, J. M., \& Nakagawa, M. (2001). Análise do Processo da Comunicação Contábil: Uma contribuição para a Solução de Problemas Semânticos, Utilizando Conceitos da Teoria da Comunicação. Revista de Contabilidade e Finanças.

Dyck, A., \& Zingales, L. (2003). The media and asset prices.

Elliot, W. B. (2004). The Effects of Pro Forma Earnings Disclosures on Analysts and Non Professional Investors Equity Valuation Judgments. The Accouting Review.

Elliot, W. B. (2006). Are Investors Influenced by Pro Forma Emphasis and Reconciliations in Earnings Announcement. The Accouting Review.

Elshafie, E., Yen, A.-R., \& Yu, M. (2010). The Association between pro forma earnings and earnings management. Review of Accouting and Finance.

Engelberg, J., \& Parsons, C. (2011). The Causal Impact of Media in Financial Markets. The Journal of Finance.

Famá, R., \& Barros, L. (outubro/dezembro de 2000). Q de Tobin e seu uso em finanças: Aspectos metodológicos e conceituais. Caderno de Pesquisa em Administração, v. 07, no4.

Fang, L., \& Peress, J. (2009). Media Coverage and the Cross-Section of Stock Returns. The Journal of Finance, vol 64 (5), pp. 2023-2052.

Fávero, L. P. (2015). Análise de Dados: Modelos de regressão com Excel, Stata e SPSS. 1. ed. Rio de Janeiro: Elsevier.

Fávero, L., Belfiore, P., Silva, F., \& Chan, B. L. (2009). Análise de dados: Modelagem multivariada para tomada de decisões. Rio de Janeiro: Elsevier.

Fávero, Lopes, L. P., Almeida, J. E., \& Takamatsu, R. T. (2014). Propensity for Growth of Stock Prices in Emerging Markets: A Logit Panel Approach. Business and Economics Journal J5:88.

Fields, T. D., Lys, T. Z., \& Vincent, L. (2001). Empirical research on accounting choice. Journal of Accounting and Economics.

Francis, J., Schipper, K., \& Vincent, L. (2002). Expanded disclosures and the increased usefulness of earnings announcements. The Accouting Review.

Frankel, R., Johnson, M., \& Skinner, D. J. (1999). An Empirical Examination of Conference Calls as a Voluntary Disclosure Medium. Journal of Accounting Research.

Gibbins, M., Richardson, A., \& Watherhouse, J. (1990). The Management of Corporate Financial Disclosure: Opportunism, Ritualism, Policies and Processes. Journal of Accounting Research.

Gouveia, F. H. (2010). Uma incursão pela abordagem de pesquisa em contabilidade no Brasil fundamentada em teorias semióticas e da comunicação. Dissertação de Mestrado. Universidade de São Paulo. 
Griffin, J. M., Hirschey, N. H., \& Kelly, P. (2012). Tagging the triggers: na empirical analysis of information events prompting sell-side analyst reports. Financial Markets and Portfolio Management.

Gujarati, D. (2006). Econometria Básica. Rio de Janeiro.: Elsevier.

Handa, P., \& Linn, S. (1993). Arbitrage Pricing with Estimation Risk. Journal of Financial and Quantitative Analysis, 28, pp. 81-100.

Healy, P. M., \& Palepu, K. G. (2001). Information Asynmetry, Corporate Disclosure and Capital Markets. Journal of Accounting and Economics. 31, pp. 405-440.

Hendriksen, E., \& Van Breda, M. F. (1999). Teoria da Contabilidade. Atlas.

ludícibus, S. (2013). Rumo à contabilidade econômica ou à nobre origem? Revista de Conabilidade e Finanças da USP.

ludícibus, S. d. (2000). Teoria da Contabilidade. Atlas.

Jakobson, R. (2003). Linguística e comunicação. Cultrix.

Jensen, M. C., \& Meckling, W. H. (2008). Teoria da Firma: Comportamento dos Administradores, Custos de Agência e Estruturas de Propriedade. Revista de Administração de Empresa-RAE, abril-junho.

Kachani, M. (2012). Área de comunicação corporativa aumenta 300\% em dez anos. Fonte: Folha de S. Paulo: http://www1.folha.uol.com.br/fsp/mercado/68890-area-de-comunicacaocorporativa-aumenta-300-em-dez-anos.shtml

Libby, R., Bloomfield, R. J., \& Nelson, M. W. (2002). Experimental Research in Financial Accounting. Accouting, Organizations and Society 27 (8), pp. 775-810.

Lima, G. A. (2013). Efeito do acompanhamento dos analistas no valor das empresas. Tese de Livre Docência. São Paulo: Universidade de São Paulo.

Lima, G. S. (2007). Utilização da Teoria de Divulgação para Avaliação da Relação do Nível de Disclosure com Custo da Dívida das Empresas Brasileiras. Tese de Doutorado. Universidade de São Paulo.

Lima, J. B. (2011). A relevância da informação contábil e o processo de convergência para as normas IFRS no Brasil. Tese de Doutorado. São Paulo: Universidade de São Paulo.

Lopes, A. B., \& Alencar, R. C. (2010). Disclosure and cost of equity capital in emerging markets: The Brazilian case. The International Journal of Accouting, 45, pp. 443-464.

Lougee, B. A., \& Marquardt, C. A. (2004). Earnings informativeness and strategic disclosure: na empirical examination of 'pro forma' earnings. The Accouting Review.

Luz, J. J., Camargos, M. A., \& Lima, J. d. (2006). Análise da relação entre disseminação voluntária de informações em sites corporativos e desempenho financeiro de empresas brasileiras. Revista de Gestão - USP. 
Martins, E., Diniz, J. A., \& Miranda, G. J. (2012). Análise Avançada das Demonstrações Contábes: Uma Abordagem Crítica. Atlas.

Merton, R. C. (1987). A Simple Model od Capital Market Equilibrium with Incomplete Information. The Journal of Finance 42 (3), pp. 483-510.

Mittendorf, B., \& Zhang, Y. (2005). The Role of Biased Earnings Guidance in Creating a Healthy Tension between Managers and Analysts. The Accounting Review.

Mizrach, B., \& Weerts, S. (2009). Experts online: An analysis of trading activity in a public Internet chat room. Journal of Economic Behavior \& Organization, Volume 70, Issues 1-2, May 2009, pp. 266-281.

O'Connor, A. J. (2013). The power of popularity: An empirical study of the relationship between social media fan counts and brand company sotck prices. Social Science Computer Review, pp. 229235.

Palepu, K. G., \& Healy, P. M. (1993). The Effect of Firms's Financial Disclosure Strategies on Sotck Prices. Accouting Horizons, 7, pp. 1-11.

Petersen, M. A. (2009). Estimating Standard Errors in Finance Panel Data Sets: Comparing Approaches. The Review of Financial Studies 22 (1), pp. 435-480.

Pippin, S. E. (2006). An analysis of the impact of tax systems on income distribution, poverty and human well-being; Evidence from cross-country comparisons. . Dissertation in Business Administration (Accouting) - Doctor of Philosophy. Texas Tech University.

Pollock, T. G., \& Rindova, V. P. (2003). Media Legitimation Effects in the Market for Initial Public Offerings. Academy of Management Journal. Vol. 46, No. 5, 631-642.

Reiter, N., \& Procianoy, J. L. (2012). Impacto Informacional das Reuniões Públicas Apimec: Um estudo de Evento. Revista de Administração do Mackenzie.

Rogers, J. L., \& Stocken, P. C. (2005). Credibility of Management Forecasts. The Accouting Review.

Saussure, F. d. (19--). Curso de linguística geral.

Silva, W. M., \& Magalhães Filho, P. A. (2005). Determinantes da disseminação voluntária de informações financeiras na internet. RAE-Eletrônica.

Solomons, D. (1966). Economic and Accounting Concepts of Income. The Accounting Review.

Souza, P. R. (1995). Análise do Atual Estágio de Disclosure das Companhias Abertas no Mercado de Capitais brasileiro e Contribuições para seu Aprimoramento. Dissertação de Mestrado. Universidade de São Paulo.

Stice, E. K. (1991). The Market Reaction to 10-K and 10-Q Filings and to the Subsquent The Wall Street Journal Announcements. The Accouting Review.

Sun, Y. (2010). Do MD\&A Disclosures Help Users Interpret Disproportionate Inventory Increases. The Accouting Review. 
Sutton, S. G., Arnold, V., Bedard, J. C., \& Philips, J. R. (2012). Enhancing and Structuring the MD\&A to Aid Investors when Using Interactive Data. Journal of Information Systems.

Tetlock, P. (2007). Giving Content to Investor Sentiment: The Role od Media in the Stock Market. The Journal of Finance.

Verrecchia, R. E. (1983). Discretionary Disclosure. Journal of Accouting and Economics, 5, pp. 179194.

Wiedman, C. (2000). Discussion of "Voluntary Disclosure and Equity Offerings: Reducing Information Asymmetry or Hyping the Stock. Contemporary Accounting Research.

Wooldridge, J. M. (2006). Introdução à econometria. São Paulo: Thompson Learning. 